\title{
DE TOBELOREEZEN IN HUN DENKEN EN DOEN
}

DOOR

\author{
A. HUETING.
}

In mijn Tobeloreesch-Hollandsch Woordenboek ${ }^{1}$ heb ik voor de verklaring van woorden meermalen verwezen naar "monografie». Dat ik eerst nu de belofte nakom welke in die verwijzing lag opgesloten, is uitsluitend toe te schrijven aan de omstandigheid dat de tijd heeft ontbroken om dezen arbeid zoo spoedig te voltooien als ik mij had voorgesteld.

Misschien zal worden gevonden dat ik ten onrechte adat en rechtspraak in deze beschrijving onbesproken heb gelaten. Over die onderwerpen heb ik echter vroeger reeds zoo uitvoerig geschreven ${ }^{2}$, dat ik slechts in herhalingen kon vervallen, wat mij niet wenschelijk voorkwam.

\section{HOOFDSTUK 1.}

\section{Woonplaatsen.}

Het district Tobelo, gelegen op de Oostkust van NoordHalmahera, tusschen de districten Kau (Zuidelijk) en Galela (Noordelijk) is geheel bezet door de hoofdstam der Tobeloreezen. Aan de Noordelijke grens wonen ook wel Galelareezen, maar nergens vormen die eene meerderheid. Het district $\mathrm{Kau}$ is Tobeloreesch van de grens met Tobelo, tot aan de hoofdplaats Kau, wier bevolking wel met Tobeloreezen vermengd is, doch

\footnotetext{
1 Uitgegeven door het Kon. Institunt v. d. Taal-, Land- en Volkenkunde van Ned. Indië 1908. 1910

${ }^{2}$ Bijdragen Dl. 63 (1909); Tijdschrift K. N. Aardrijkskundig Genootschap 1905; Meded. Ned. Zendel. Genootschap Dl. 50 (1906).
}

Dl. 77. 
toch niet Tobeloreesch genoemd mag worden. Van die hoofdplaats, tot aan de grens van het district Kau, vindt men aan de kust dorpen van andere stammen; verderop naar het zuiden, in het Dodingasche, beginnen echter al weer Tobeloreesche dorpen. Het gedeelte van het district Dodinga, dat aan de Kau-baai grenst, is bijna geheel door hen ingenomen. Hun hoofddorp aldaar is Pasirputih. Tijdens den-opstand onder Dano Hassan, zijn velen uit het district Tobelo zelf daarheen uitgeweken. Aanvankelijk is daar vermenging met de oorspronkelijke bevolking voorgekomen, maar nu hebben de Tobeloreezen ook daar de overhand.

Langs de oostzijde van de Kau-baai vindt men eveneens verscheiden Tobeloreesche dorpen, zelfs nog in de Boeli-baai. Ook in de Weda-baai worden Tobeloreesche nederzettingen aangetroffen. Het eiland Morotai, aan de noordpunt van N. Halmahera, is tevens voor een gedeelte door hen in beslag genomen, en hun koloniseerende aanleg kan wel hieruit blijken, dat men ook op de noordkust van Ceram, op Boeroe, in de Soela-Archipel, in de Banggai-Archipel, op de Batjan-groep, overal Tobeloreezen vindt, die, waar zij komen, zich weten te handhaven. Dat ligt voor een deel aan hun karakter en aard, zooals men uit de beschrijving daarvan zien zal.

Er kunnen alzoo drie hoofdgroepen naar hunne woonplaatsen worden onderscheiden, nl. de bewoners van het district Tobelo zelf, de Tobeloreezen die in het district Kau wonen, en die uit het district Dodinga. De eerste groep noemen wij alleen Tobeloreezen, of "eigenlijke Tobeloreezen», de tweede Kausche Tobeloreezen, de derde Dodingäers. Zij die de dorpen bewonen Oostelijk aan de Kau-baai gelegen, behooren voor het meerendeel tot de Kausche Tobeloreezen.

\section{HOOFDSTUK 2.}

\section{Naam.}

Moeilijk valt uit te maken, wat de naam "Tobelo» beteekent. "To» wordt aangetroffen voor de namen van verschillende Halmaherasche volkstammen, b. v. b. Tobaru, Tololiko, maar daarnaast heeft men: Galela, Loda, Madole, Sùùru, 
Waioli, Isam. Dat dit "To» "mensch» beteekent gelijk in "To» voor vele namen van stammen op Celebes het geval is, en "Tobelo" alzoo beteekent "belo-menschen»(belo = staak), is niet onaannemelijk, maar staat geenszins vast.

Een oud verhaal zegt, dat de Halmahera-volken van over zee kwamen en dat toen hun Hoofd hun toeriep: "o ngotiri ni ja bèlo»= leg de prauw aan een staak, de lui voor 't gemak maar zelf de prauw vasthielden, en daarom Tobelo $=$ staaklui genoemd worden. Het " $\mathrm{T} o$ » moet dan echter verstaan worden als pers. voornaamw. enkelv. "ik» dus: ik houd de prauw vast, of: ik leg de prauw aan een staak. Heel waarschijnlijk klinkt deze verklaring niet!

Volgens een verhaal onder de Galelareezen, zouden deze volken vroeger overheerscht geweest zijn door den Vorst van Batjan, en toen aangewezen zijn geweest, om voor de staken van diens prauwen te zorgen, en vandaar: tobelo: staaklui. Daar nu echter historisch niets bekend is van een Batjansche overheersching van deze streek, kan men dit ook gerust tot de legenden rekenen.

Volgens anderen zou de naam herkomstig of gevormd zijn van " tumbelo" = duiken bij den staak, een soort godsoordeel, dat hier vroeger, en misschien ook nu nog hier en daar, in zwang was, waarbij twee lieden doken bij een in zee gestoken staak, of belo, en diegene tot schuldige werd verklaard, die het eerst boven kwam. Aangezien men nu echter in geen der Halmahera talen, dit duiken zoo kort benoemen zou, maar men b.v.b. in het Ternataansch zou zeggen: "tum toma belo", in het Tobeloreesch: "hotumunu o belohuku», is dit ook al niet heel waarschijnlijk.

Wij komen alzoo tot de slotsom, dat niet valt uit te maken wat de juiste beteekenis is van den naam, het blijft bij gissingen.

$\mathrm{Nu}$ rest nog de vraag, of de bewoners hun naam aan het land gegeven hebben, of eenvoudig genoemd zijn naar het land waarin ze zich neerzetten.

Voor het eerste pleit dat volgens Tiele (Bijdragen $4^{\mathrm{e}}$ Reeks, deel VIII) reeds in 1606 gesproken wordt van Tobelo en Galela. Er staat daar n.l. dat de Sultan van Tidore een bezetting moest achterlaten te Tolo, om de bevriende bevolking te vrijwaren voor aanvallen van lieden van Galela en Tobelo. Ook komt op 
een oude zeekaart uit de $1 \overline{7}^{\mathrm{e}}$ eeuw de naam "Tobelo" voor. Dit nu klopt niet met de verhalen omtrent de afkomst der Tobeloreezen door hen zelf gedaan (zie hoofdstuk afkomst) volgens welke de stam wel niet langer dan 150 à 200 jaar aan de kust gewoond heeft. Men zou daaruit moeten opmaken, dat de streek reeds "Tobelo" heette vóór de stam zich er neerzette. Ook pleit voor deze meening dat de lieden zich noemen: "o Tobelohoka = lieden van Tobelo. Maar hiertegen kan worden aangevoerd dat de lieden beweren altijd als stam Tobeloreezen geheeten te hebben; dat het gedeelte van den stam, dat niet in het district Tobelo, maar in het district Kau woont, en zich daar dadelijk na den uittocht uit het binnenland, neergezet heeft, zich eveneens: "o Tobeloho, noemt, dat ze ook voor hun taal geen andere naam hebben dan "ho totobèloho»: Tobeloreesch spreken, dat ze door de andere stammen aangeduid worden als: Tobeloreezen van de negen rivieren en Tobelo Bòëng, de Tobeloreezen die daar wonen aan de negen rivieren en aan de rivier Boëng. Dit alles pleit er sterk voor, dat de stam Tobelo heette, en zijn naam aan het land gaf.

Om dan het reeds vroeg genoemd worden, van den naam Tobelo te verklaren, kan men aannemen òf, dat de uittocht van den stam naar de kust veel vroeger plaats had, dan de bevolking thans beweert, ò wel, dat zij nog in het binnenland wonende, reeds haar naam aan de streek gegeven heeft.

\section{HOOFDSTUK 3.}

\section{Stamverdeeling.}

De Tobeloreezen uit het district Tobelo zijn verdeeld in vier onderstammen "o hoana" geheeten, hetzelfde woord dat in het Moluksch-Maleisch "soa» heet en: afdeeling beduidt. Door de Ternataansche Hoofden werden zij daarom officieel aangesproken als manusia soa ràhà, lui van de vier afdeelingen. Deze afdeelingen heetten: o Lina, o Huboto, o Momulati en o Gura. De laatste, o Gura, is bijna geheel opgegaan in o Hibua lamo, de groote loods of tempel. Dit is wel geen aparte afdeeling, maar deze heeft haar oorsprong te danken aan eenige recalcitrante lui van de afdeeling $\mathrm{Gura}$, die tezamen 
een grooten tempel bouwden, en daaromheen een dorp stichtten, een soort onderafdeeling dus, maar die de hoofdafdeeling bijna in vergetelheid heeft doen geraken.

De ho an a Lin a geldt als de voornaamste, de hoofdafdeeling. Men zegt dat die het eerst bereid was tot den uittocht naar het strand, en daarom ook heet: o hoana momole; de dappere afdeeling. Waar is, dat zij in alles den voorrang hebben. Was er iets aan de hand, dan vormde Lina altijd de voorhoede, al was het ook maar door een aankomenden jongen vertegenwoordigd. Ook hadden de mannen van die afdeeling het recht om voor de Ternataansche Hoofden te verschijnen, met een sarong schuin over den schouder hangende (ho hekola), 't geen aan de leden van de andere afdeelingen niet veroorloofd was.

$\mathrm{Nu}$ zal tot die oppermacht wel bijgedragen hebben, dat het de sterkste, de talrijkste afdeeling is. Op haar volgt Gura, terwijl de beide anderen heel wat kleiner zijn. Tusschen Lin a en Gura heeft wel rivaliteit bestaan, zooals nog uit de oude zangen blijkt, reeds tijdens het wonen in het binnenland. Daar het nu zeer duidelijk is, dat Lina de recalcitrante lui uit Gura, die den Hibua-1amo bouwden, bijgestaan heeft, is dat wellicht wel een min of meer politieke zet geweest, om het overwicht te handhaven.

Dat Lin a werkelijk altijd de eerste geweest is, blijkt ook nog daaruit dat het de leider is bij verschillende ceremonien, en dat hun stamgeest "wongemi * altijd het eerst aangeroepen wordt.

Men heeft vroeger, ook aan de kust, dorpsgewijze gewoond, elke "hoana» apart; eerst op «Gamhoku *'t verbrande dorp, later ook te Gamhungi 't nieuwe dorp. Elke afdeeling woonde daar onder haar eigen Hoofd. Die Hoofden zijn: ma Hangadji 't hoogste Hoofd, uit de afdeeling Lina. Verder voor elke afdeeling een $\times \mathrm{Hukum}$ » een afdeelingshoofd; met een of meer Kimelaha eigenlijk Kimelāa, onderhoofden, later kamponghoofden, die weer hadden hun ma dimeno, Ternataansch "mahimo» oudste, die echter wel zoowat de rol van boodschaplooper van den Kimelāa vervulde. Ook had men nog “o ngohaka ma riaka» een soort hoofden hooger, dan Kimelāa, aangesteld door het Ternataansch Bestuur. In het Ternataansch is dit ngofa manjira: oudste zoon, een soort hoftitel, maar die toch ook al heel oud is, want in het Binnenland schijnt men die al gekend te hebben, zooals uit de ge- 
schiedenis der Kausche Tobelo's blijkt. Ook had men nog "o Kapita", krijgshoofden. Nu werd men door die hoofden bestuurd, eigenlijk met elkaar één groot dorp vormende, totdat er in 1870 omstreeks, een $\mathrm{Hangadji-districtshoofd,} \mathrm{aangesteld}$ werd niet volgens den adat, want deze was uit de afdeeling Momulati. Deze man heette Madon, was rooverhoofdman, woonde te Gaàne, aan de Zuidpunt van Z.-Halmahera, en om der wille van zijn vele zeerooverijen, was op zijn hoofd een prijs gesteld. Dit had ten gevolge, dat hij gevangen genomen werd. Waar nu echter elk verwachtte, dat de man gehangen zou worden, gebeurde dit toch niet, maar hij werd aangesteld tot Hoofd der Tobeloreezen.

De volksmond verklaarde dit, door te zeggen, dat de man zich bereid verklaarde gehangen te worden, mits men zijn compagnon ook hing. Die compagnon zou de Sultan van Ternate geweest zijn, en uit hoofde van dit doorluchtige compagnonschap, zou de man begenadigd zijn geworden. Hoe dit zij, hij was een zeer krachtige figuur, die zich hoogst verdienstelijk maakte, door de Tobeloreesche zeeroovers uit alle schuilhoeken op te sporen, en ze te dwingen zich voortaan rustig te houden. Minder goed was dat hij, bij gelegenheid dat zijn hoana twist kreeg met een ander, toestond dat zijn lieden zich van de algemeene

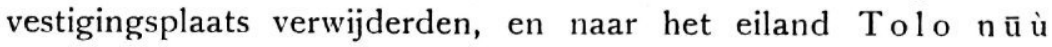
verhuisden. Dit opende n.l. den weg ook voor de anderen, om te gaan wonen waar men maar beliefde, en daar men natuurlijk van vroeger reeds hier en daar aanplantingen had, ging men nu al spoedig door het heele district verspreid wonen, en de hoofdvestiging verviel.

In het Zuiden van 't district lagen van vroeger reeds, èn op het eiland Méti, èn op den vasten wal daartegenover, dorpen, bewoond door lieden van de afdeeling $\mathrm{Lina}$, bestuurd door onderhoofden van die afdeeling, die tot taak hadden het district daar tegen indringers te verdedigen. Dit bleef zoo, maar voor het overige ging men hier en daar verspreid wonen, zonder bepaalde kampongs te bouwen, elk in zijn tuin, naar elks hartewensch.

Een hoogst ongeregelde toestand dus, waaraan pas een eind gemaakt is, toen als gevolg der christianisatie in 1898, het Binnenlandsch Bestuur zich meer met de Tobeloreezen ging bemoeien. 
De stam der Kausche Tobeloreezen bestaat ook uit vier Hoanas, n.l. Bòëng, Tunuai, Seleruru en Madong. De grootste van deze afdeelingen is Bò ëng, waarom men ook wel al de Kausche Tobeloreezen Bò̈ngs noemt. Zij zelf echter doen dit niet, maar noemen zich allen o Tobelohoka $=$ Tobeloreezen. Alleen de lieden van de afdeeling Bòëng zelf, laten zich de naam natuurlijk welgevallen, maar de anderen niet, die beweren soms heftig: ik ben geen Bò ëng!

Deze Tobeloreezen hebben na hun uittocht uit het binnenland, nooit bij elkaar gewoond, zooals de eigenlijke Tobelo's, maar elke Hoana op zich zelf in dorpen, gelegen aan de rivieren, waarnaar ze benoemd' zijn. Van het Noorden naar het Zuiden is dat een kuststrook van eenige uren lang, waaraan die dorpen liggen. Het eigenlijke dorp Kau hebben zij nooit bewoond. De bewoners van die districthoofdplaats zijn een mengelmoes van allerlei; met heel weinig Tobeloreezen.

Ook hier heeft men dezelfde rangen van Hoofden, waarbij de $\mathrm{Hangadji}$ van Bòëng $u u$ het opperhoofd is. Het schijnt echter wel, dat het onderling verband niet zoo hecht geweest is als bij de eigenlijke Tobelo's, en dat het gezag van den Hangadji Bòèng, pas door Ternate ook over de andere Hoanas is geldende gemaakt. Wellicht heeft daartoe bijgedragen, dat dit Hoofd vroeger Mohammedaan geworden is, en dus daardoor waardig gekeurd werd den Sultan van Ternate te dienen. Men houdt hardnekkig vol, dat b.v. de Ngofa manj i r a 13 ò ëng oorspronkelijk meer aanzien genoot dan den $\mathrm{Han}$ ga j ji. Men brengt dit in verband hiermede, dat vroeger, tijdens het wonen aan het Meer van Lina in het binnenland, een Vorst van Djailolo, vluchtende voor de Ternatanen, daar aangekomen zou zijn, en bij den $\mathrm{Ng}$ ofa manjira bescherming gevonden zou hebben. Deze Vorst zou daarom ook dien Ngofa manjira Bòëng, als hoogste Hoofd aangesteld hebben, en de stammen uitgeleid hebben naar het strand. Deze Radja wordt Piter Dam genoemd.

$\mathrm{Nu}$ leest men in Tiele, deel II, Bijdr. v. h. Koninkl. Instit. $4^{\text {e }}$ reeks III, dat in 1533 de toen met de Portugeezen verbonden Spanjaarden, Djailolo wilden verlaten, waar zij zich gevestigd hadden, nadat de Koning van Djailolo, hen tegen Ternate had bijgestaan. De Koning van Djailolo vond dit echter niet goed, daar hij vreesde voor Ternate. Toen nu Djailolo aangevallen 
werd door Tidore, Batjan en Ternate, moest de Koning van Djailolo vluchten, en ontkwam naar het binnenland. Hoe die Koning heette, wordt niet opgegeven, maar het is kennelijk dezelfde die, volgens dezelfde bron, in 1535 door zijn Rijksbestierder Kaitjil Boemie, om hals gebracht werd. Is dit de Radja van Djailolo waarvan dit verhaal spreekt, dan valt de uittocht der Kausche Tobeloreezen reeds in 1533 of 1534.

Ook zijn bij de Kausche Tobelo's de Hoana's of afdeelingen, meer uit elkaar gevallen, dan bij de eigenlijke Tobeloreezen, want, waar men daar voor een $\mathrm{Hoana}$ verschillende hoofden had; maar toch steeds bij elkaar bleef, is hier elke Hoa n a nog weer onderverdeeld in $\mathrm{Ho}$ an as, naar de Hoofden die men had. Bòëng b. v. in Hoana Hangadji, Hoana Hukum, Hoana Ngofa manjira en Hoana Tungulu, de Hoanas Tunuai en Seleruru, elk weer in een Hoana Ngofa manjira en Kimalāa, en de Hoana Madong in een Hoana Kimalāa en Mahimo. De saamhoorigheid is hier dus niet sterk, temeer niet, daar elke onderafdeeling ook weer haar eigen stamgeest, (wongemi) heeft.

\section{HOOFDSTUK 4.}

\section{Geschiedenis.}

Omtrent de afkomst der Tobeloreezen bestaan verschillende verhalen. Allen stemmen daarin overeen, dat zoowel de Tobeloreezen als de Galelareezen van over zee gekomen zijn.

Het eene verhaal luidt ongeveer aldus: De Halmahera bewoners zijn, op zee verdwaald zijnde, aangedreven boven Gaäne, aan de Zuidspits van het Z. Schiereiland, op de plaats nu nog Djuangana ruba ruba (Ternat. djuanga =een heel groot soort prauw, ruba ruba= vergaan, omvallen) geheeten.

Vandaar verspreidden zich allen naar hun respectievelijke woonplaatsen en districten, de meesten met prauwen, de Tobeloreezen en Galelareezen over land. Beide stammen trokken op onder één hoofd. De Galelareezen hadden als hun erfdeel uit de vergane prauw een kanon (lèla) meegenomen, en de Tobeloreezen twee reusachtige gongs. Gekomen tot de landengte van Pajahe, de N.-grens van het Z.-Schiereiland, konden de Galelareezen hun kanon niet meer dragen en lieten het vallen op een berg 
tot heden bukuspera geheeten. (Ternat. buku= berg, uspera $=$ kanon, kanonberg). Vandaar zette men den weg voort tot aan de plaats, waar het tegenwoordige meer Gura of Lina ligt, in het binnenland van het district Kau. Daar was veel sagoe, maar het meer bestond nog niet. Men had dus wel spijze, maar was over de plaats nog niet tevreden, daar men aan zee wilde wonen. Het Hoofd zocht dus langs den vulkaan Dukono (Tolo) naar zee te komen, door het dal der rivier Mèdee, en kwam toen aan de kust, ter plaatse waar nu de kampong Mèdee ligt. Daar was het land echter zóó slecht, dat men maar weer naar het binnenland terugkeerde. - 't Is niet onmogelijk dat dit geweest is, kort na de groote uitbarsting van de vulkaan Dukono in 1551, zoodat toen de grond onbruikbaar was. -

$\mathrm{Nu}$ kregen Galelareezen en Tobeloreezen twist over de meegebrachte gongs. De Galelareezen beweerden op één ervan recht te hebben: de Tobeloreezen ontkenden dit, en daar de Hoofden de Tobeloreezen gelijk gaven, wijl de Galelareezen hun erfdeel, het kanon, gehad hadden, verwijderden zich de Galelareezen, één gong meenemende. Zij gingen naar den berg Lahia (?) en woonden aldaar, tot zij verderop gingen, en hun gong op.dien berg achterlieten, die daar nog is tot den huidigen dag.

$\mathrm{Nu}$ is het wel vreemd, dat in dit verhaal de Tobeloreezen zich als één van afkomst met de Galelareezen verklaren, van wie ze anders door hun adat nog al onderscheiden zijn. Echter, volgens den Heer van Baarda, bestaan de Galelareezen, ook nog uit twee deelen, die zelfs aan de uitspraak zijn te onder. kennen. Heel onmogelijk is het dus niet, dat tusschen het eene deel der Galelareezen en de Tobeloreezen, oorspronkelijk nadere verwantschap bestaan heeft.

Dat het verhaal echter alle Halmahera-bewoners tezamen laat aankomen is wat sterk, daar die toch in yerband met hunne talen in twee hoofdgroepen zijn te onderscheiden, hoewel het natuurlijk ook nog mogelijk is, dat tijdens de eerste aankomst van de bewoners van het N. Schiereiland, het heele eiland nog onbewoond was, en de tegenwoordige bewoners der andere schiereilanden, volgens hun talen met de Papoeas verwant, pas later aangekomen zijn, en de eerste bewoners verdreven hebben.

Een ander verhaal noemt, als plaats van herkomst, het land van Makassar, waaronder men geheel het Noordelijk deel van Celebes verstaan kan. 
Weer een ander verhaal zegt: wij zijn herkomstig uit het land Sèkel, van de Manilareezen. Wij zijn op vlotten hier aangekomen. Eén vlot strandde op Gola uku, dicht bij Morotai (gola = rots, gola $\mathrm{uku}=\mathrm{op}$ de rots). Zeven vlotten gingen recht door naar Tobu(?). Daar ging men aan land, en trok recht door naar het meer Lina.

Uit dit alles is alleen op te maken, dat de Tobeloreezen van over zee op Halmahera gekomen zijn, maar omtrent het vanwaar geven deze legenden weinig of geen uitkomst.

In elk geval zal, met het oog op de taal, wel aangenomen moeten worden dat al de stammen van het N. Schiereiland, met de bevolking van Ternate en Tidore, één oorsprong hebben.

Als historisch staat alleen vast, dat de Tobeloreezen in vroegeren tijd in het binnenland van Kau gewoond hebben, aan het tegenwoordig meer van Lina of Gura. Hoe lang? Dit valt zelfs niet bij benadering vast te stellen, ook niet uit de volksverhalen. Alles verliest zich in mythische verhalen. Natuurlijk is in al de verhalen wel iets waarheid, maar de oudste historie van Halmahera is eigenlijk totaal onbekend, zoodat het wel nooit mogelijk zijn zal waarheid en verdichting van elkaar te scheiden.

Betrekkelijk vast staat alleen hun wonen aan het Meer, en hun uittocht vandaar naar de kust.

Ik laat hier eerst een paar verhalen volgen hierover, zooals die mij verteld zijn door de bevolking.

Bij de aankomst aan het meer Lina was de Oudste Tingidu, de voorvader van mijn zegsman, en tot heden de stamgeest van de Hoana Lina.

De Sangadji van Gamkonora (een district aan de W.kust van N. Halmahera) Pahiwáni geheeten, kwam visschen op de rivier Kua, (dit is een kleine rivier die aan de O.kust in de baai van Patja uitmondt).

De honden van Tingidu werden door den Sangadji gezien. Deze keerde nu terug, en haalde ook zijne honden. Hij kwam over den berg Hiko(?) en de uitloopers van den Kotai (de meest Zuidelijke uitloopers van het Tobeloreesch gebergte), toen zijn honden aansloegen. Hij daalde van den berg af, en vond Tingidu, en nog een koning meegekomen van Manilla, Kadjadian geheeten, met veel volk. Die koning Kadjadian stierf reeds vóór dat de Sangadji Gamkonora naar zijn land teruggekeerd was. Hij werd opgevolgd door koning Haraitawi. Daarna bracht de 
Sangadji van Gamkonora, de lieden naar het strand te Patja (patja = verzamelen. Ternat.) Dit Patja geldt algemeen voor de oudste nederzettingsplaats aan het strand. Daarna ging de Sangadji met Kapita Halaka terug naar Gamkonora, en het volk bleef onder Tingidu wonen te Kupa-kupa, vlak bij Patja, aan het strand gelegen.

De Sangadji was met Kapita $\mathrm{Halaka}$, en een deel volks vertrokken met een groote prauw (djuangana). Aan kaap Djere beval de Sangadji de prauw vast te leggen, te bélo, maar het volk hield dien vast, dus Tobelo. Hij bracht de prauw te Linga, en dus werd dat een Tobeloreesche kolonie. - Dit Linga moet aan de Westkust liggen, maar de juiste plaats is mij niet bekend. - Daarna kwam de Sangadji Gamkonora terug en wilde weer volk meenemen, maar Tingidu wilde dat niet toestaan.

$\mathrm{Na}$ den dood van dezen $\mathrm{T}$ ingidu, ging het opperbevel over aan diens zoon, weder Tingidu geheeten. De zonen van dezen Tingidu waren Pogu-poguru en Djangu. De zonen van Pogu-poguru waren Handiki en Rako, de zoon van Rako was Ihanga, en de zoon van Ihanga is Toloko, de man die mij dit verhaal mededeelde. Hij is nu een bejaard man, maar zijn Vader Ihanga, heb ik toch ook nog jaren lang gekend. Als dus deze geslachtsboom juist is, zijn de hier medegedeelde gebeurtenissen nog niet heel lang geleden, hoogstens een 200 jaar. Wellicht is de opvolging Ting idu-Pogu-poguru. Rako, Ihanga, Toloko, wel juist, maar hoogst waarschijnlijk is tusschen dezen Tingidu, en de Tingidu die nu nog als stamgeest vereerd wordt, een lange tusschenpoos.

Een ander verhaal luidt aldus: De Tobeloreezen woonden op de plaats waar nu het meer Lina is. $\mathrm{Zij}$ woonden toen reeds verdeeld in de twee hoofdafdeelingen, en elke stam in zijn afdeelingen, zooals het nu nog is. Het meer echter was er nog niet. Maar een meisje ‘Djangutu geheeten, was geëngageerd met een jongeling van Galela. Het meer van Galela bestond toen reeds. Het meisje verzocht haar minnaar, haar wat van het Galelasche meerwater mee te brengen, wat deze deed, in een waternimfen. blad. $\mathrm{Z}_{\mathrm{ij}}$ bekeek het, maakte een kuiltje, deed het water daarin, en dekte het met het blad toe. Den volgenden morgen was het water reeds toegenomen, en nog een dag later, dreef het blad op het water. Het nam nu steeds in omvang toe, zoodat de 
nederzetting er door wegspoelde, ook de meegebrachte gong uit de vergane prauw verzonk, maar de menschen verdronken niet, want het meisje plaatste zich bij een boom, to r obuk u geheeten, en zeide dat het water niet verder dan tot dezen boom komen mocht. Op hare bezwering stond ook het water stil, omdat zij zich aanbood, als prijs daarvoor, een rots te worden. $\mathrm{Zij}$ stapte in den boom, en verdween daarin. Wanneer men later in dien boom hakte, vloeide er bloed uit.

Hetzelfde verhaal wordt ook, eenigszins gewijzigd, medegedeeld omtrent het meer Sango of Patja, een uur of zes van de kust, achter de kampong Patja gelegen. Dạarvan vertelt men het volgende. De eigenares van het meer Patja is $\mathrm{ngo}$ Memeua (Moederloos).

Haar broer, o Kububu, ging achter de bergen langs vrijen met een meisje te Galela, en bracht voor zijn zuster, op haar verzoek, iets mede van het mooie meerwater aldaar, in een bamboe. $Z_{i j}$ groef een put, en deed het daarin. Zij dekte het toe met een caladium blad.

Den volgenden morgen dreef het blad. 's Nachts maakten de lieden van het dorp feest, met gezang en dans en palmwijn drinken. Toen kraaide een haan: totiri, i roroua gamu djaha (niet lang en het dorp verzinkt. Ternat). Toen zeide de waterplantster: houdt op met op de trom te slaan, een haan kraait. Maar de lieden zeiden : zij liegt, haar kind huilt, dus wil ze niet hebben dat we kloppen.

Toen kraaide de haan wederom met dezelfde onheilspellende woorden. $\mathrm{Nu}$ hoorde het volk het ook, en zeide: werkelijk, luister! Daarna begon de bron te borrelen, het water begon te stroomen, en het volk verdronk. Maar M e m e u a liep weg Noordwaarts naar een to ro bu ku boom. Het water stroomde haar achterna, maar zij verborg zich in den boom, en bezwoer het water zeggende: hier moet de grens zijn, en het water hield daar stand.

Me dunkt, beide verhalen geven zoowat reden tot het vermoeden, dat èn het meer Lina, èn het meer Patja, vulcanische inzinkingen zijn, wellicht ontstaan in de vijftiende of zestiende eeuw, omdat in dien tijd de geweldige uitbarsting van den vulkaan Dukono wijst op een verhoogde vulcanische werking in den Halmahera-bodem.

Het eerste verhaal gaat verder, en zegt, dat tot het ontstaan van het meer de Tobeloreezen nog niet met de buitenwereld in aanraking gekomen waren. $\mathrm{Nu}$ echter kwam de Sangadji van 
Gam-konora, Ramedi geheeten, in de buurt van de nederzetting jagen. Hij zag echter de Tobeloreezen niet, want die kenden nog de kunst om zich onzichtbaar te maken, evenals de aardmannetjes, de Moroka. - Onder dit woord verstaat men de z.g.n. verdwenen vroegere bevolking van het eiland Morotai. $\mathrm{Hij}$, de Sangadji, hoorde echter kippen kakelen, ook sloegen zijn honden aan, zoodat hij begon te vermoeden in de nabijheid van menschen te zijn. Daar hij ze echter niet vinden kon, ging hij terug, en haalde al zijn honden, om daarmede de bewuste plek weer op te zoeken. Hij zelf verborg zich, maar nu begonnen zijn honden te vechten met de honden der Tobeloreezen. De Tobeloreezen zelf, ontstemd over zooveel honden, en niemand ziende, kwamen te voorschijn, en sloegen de vreemde honden, maar nu kwam ook de Sangadji uit zijn schuilplaats, en daar nu een vreemdeling de Tobeloreezen gezien had, was de betoovering der onzichtbaarmaking verbroken.

Het gevolg was, dat ze met den Sangadji bekend en bevriend werden, die hen ook straks overhaalde, om naar de kust te gaan. Men ging dus op weg, de hoofdstam N.Oostelijk, de Kausche Tobelos Z.Oostelijk de Kau-rivier volgende. Men kwam langs verschillende bergen en over rivieren, die door verzen in het geheugen bewaard gebleven zijn. Men kwam achter de tegenwoordige kampong Patja, te Kieuw, en at daar onder een grooten, thans nog bestaanden, waringinboom. Bij dat eten sprak het Hoofd de volgende dichtregelen, een half Tobeloreesch, half Ternataansch gerijmel, dat echter door zijn volk als hooge wijsheid bewonderd werd.

Dopolo-dopolotamolo ma sosioko: Hoofden elk een rijstkoek.

Kuasa-kuasa bobalata i ma momileko: onderdanen elk een stuk sagoe.

Het is dus een feestmaal geweest, waarbij men toosten sloeg.

Men zette zich neer in de kampong Patja, en verhuisde pas later naar Gamhoku. Natuurlijk heette dat dorp pas Gam hoku, nadat het door H. M. Vesuvius in brand geschoten was. De Tobeloreezen hebben het vroeger wel gewoon: o berera $=$ het dorp, genoemd.

Men ging toen, tezamen met de Galelareezen en Lodareezen met den Sangadji van Gamkonora mee op zeeroof, maar later wilde men dat niet meer, en ging er alleen, voor eigen rekening op uit.

Omtrent het verblijf aan het Meer zijn nog allerlei verhalen, 
als: De hoofdstam woonde aan de rivier de Tuguis, de Kausche Tobelos, aan de rivier Bòeng. (De Tuguis is de rivier die uit het Meer Lina vloeit, en een der hoofdbronnen is voor de Kau rivier). De lieden van de Hoana Gura woonden op het eiland in het meer. Ze wilden zich echter ook in de rivier baden, maar dat werd door het Hoofd van de Hoana Lina niet toegestaan. (W'ellicht wordt bedoeld, dat de rivier alleen gebruikt mocht worden voor het ceremonieele baden. Zie hoofst. oorlogsgebruiken). Toen men zich nu toch in de rivier baadde, wekte dit den toorn der geesten op, zoodat de rivier droog werd. Toen bad het Hoofd van Lina tot de geesten (of de goden) met een bezweringsformule (dola bololo) als volgt:

Papaua njau delo de tjakalang-visch is vaderloos Kagunguma njare-njare de prauwen leggen droog Toma buku ma liketo Dome ma lako Boki mi ake. aan de zijden van den berg (aan) de mond van de Dome (in) de Princes haar water.

Daarop keerde het water in de rivier terug.

Men staat verwonderd over de eenvoudigheid van deze, en ook van andere bezweringsformules, waarin het bezwerende zeker heel ver te zoeken is. De tjakalang is een soort zeevisch, en de Dome is een klein riviertje in het Dodingasche.

$\mathrm{Bij}$ een andere gelegenheid zou $\mathrm{T}$ ingidu een droogte voorkomen hebben door de volgende "dola bololo»:

Telaga Gura i otu Het meer Gura is droog Buru ka jo linga-linga De garnalen kruipen (als) over het land. Fo sidagi budi koga Welke wijsheid moet men aanwenden? Djou ma bala i lomo Het volk van den Heer is verzameld Ja( $\left.{ }^{1}\right)$ rara sidutu Zoo lang geleden, totdat

$\mathrm{Ka}$ mangongadje reua Er zelfs geen bericht meer van is $\mathrm{Subaka}$ fo airani (Men)buigtzichslechtsmetverwondering

Een ander verhaal vertelt: een Tobeloreesche vrouw was gevangen genomen door Tobaru-menschen, en getrouwd aan een hunner.

Zij kwamen over een rivier met één hooge oever. Daar moest zij haar man luizen. Opkijkende zag ze van den laag gelegen

1 Ik vermoed dat hier roro: lang geleden, moet staan, on niet rara: zes, en heb het ook aldus vertaald. 
oever, haar verwanten naderen, en streek dus haar man het haar in de oogen, steeds luizen knippende, terwijl ze zong:

O Gura de o Lina

Ko i teke lolilaliua

Ma wange i tjako-tjako

De hutu bolo mediri

Karana djoku ni gamu.
De afdeelingen Gura en Lina Gaan niet tezamen achteruit

De zon is al gedaald

En morgen of overmorgen

Treft het onheil je dorp.

Aldus zingende gaf ze haar verwanten steeds teekens, zich stil te houden. Haar man vroeg haar, wat ze zong, maar ze zeide: niets, ik zing maar. Intusschen waren echter haar verwanten genaderd, en sloegen den Tobaru het hoofd af, en evenzoo werden de andere Tobarus gesneld, hetgeen gemakkelijk ging, omdat ze allen met het hoofd op zijde liepen, aangezien zij het van de Tobeloreezen geroofde op den schouder droegen.

Volgens een variatie van dit verhaal, was de vrouw per ongeluk zelf gesneld geworden, maar had haar hoofd in de handen genomen, en aldus dit gedicht uitgesproken. Hoe dat mogelijk was zegt het verhaal niet.

Tusschen de stammen Tobaru en Tobelo schijnt altijd een soort vijandschap bestaan te hebben. Tot heden nog, kan men van de Tobaru's hooren, dat de Tobeloreezen koppensnellen, en hetzelfde kan men ook van de Tobeloreezen hooren, omtrent de Tobaru's, hoewel gelukkig geen der beide stammen zich aan dat misdrijf schuldig maakt. De ongunstige berichten omtrent de Tobeloreezen bij Willer e. a., moeten zeker voor een deel er aan toegeschreven worden, dat de berichtgevers Tobaru's van de Westkust waren.

Verder zijn er nog verhalen omtrent den tijd toen men voor het eerst kustbewoners geworden was. De lui waren toen nog maar een soort halfmenschen. Roeien kenden ze niet. Men wilde oversteken van Katana naar het eiland Makaliho, een afstand van hoogstens 10 minuten roeiens. Men ging in de prauw zitten, en roeide, en roeide, echter zonder vooruit te komen, want men streek de pagaaien overlangs door het water. Nadat men aldus een dag en een nacht geroeid had, deed een der roeiers per ongeluk een verkeerden slag, de pagaai dwars houdende, en zietdaar, de roeikunst gevonden.

Het zien van de zee maakte de menschen heelemaal uitzinnig. Men ging op rotsen zitten om er mede te varen. In het 
Kausche, in de bocht van Pediwang, ligt een rots, o gerèbongo: uitzinnig, geheeten. Daar ter plaatse was een dorp of nederzetting. Er voor in zee, ligt een stukje rots, als een eilandje. Daarop gingen alle mannen zitten roeien om op zeeroof uit te gaan. Ze vertrokken des avonds, en roeiden den heelen nacht als dollen, zoodat ze ook heelemaal dol werden. Tegen den morgen hoorden ze de hanen kraaien, in hun eigen dorp natuurlijk, maar ze dachten dat ze nu wel in een vreemd land waren, en sprongen dus, in dolle moordlust, aan land, en woedden daar tegen al wat leefde. De verschrikte uitroepen hunner vrouwen en kinderen, zetten hun woede nog meer aan, want ze herkenden niemand en vermoordden alles. Alleen een oude vrouw wist te ontkomen, en toen ze, na het bloedbad uitrustten, toonde die hun aan, wat ze eigenlijk wel uitgevoerd hadden. Hierover werden ze nu weer zoo verbitterd en woest, dat ze op elkaar aanvielen tot geen hunner meer in het land der levenden was.

Niet ver van onze woning wees men een plaats aan, waar dat voorgeslacht een soort tempel gehad zou hebben, waar zij drinkgelagen aanrichtten. Elk had daarbij een zwaar stuk hout met handvatsel, o pau pa geheeten, klaar. Bij 't minste vermoordden ze elkaar daar mee. Kwam iemand in 't zicht, dan riepen ze hem uitnoodigend toe: ino! ino! o pau-pau ino; kom, kom, kom naar de pau pau! kwam iemand op die roepstem, dan bood men hem palmwijn aan, in een dunne bamboe-koker, scherp aangepunt, o waloko, en bracht dan de gast dien koker aan den mond, en boog daarbij het hoofd achterover om te drinken, dan kwam dadelijk iemand, die met de pau pau een harden slag onder tegen den drinkbeker gaf, zoodat den gast de bamboekoker dwars door het hoofd geslagen werd, uit louter moordlust.

Kortom, volgens de verhalen waren die eerste kust-Tobeloreezen, een soort ruwe moordlustige wilden.

Dat het uit het binnenland naar de kust verhuizen, een vooruitgang geweest is op cultuur gebied, valt natuurlijk niet te betwijfelen. Een voorbeeld daarvan bieden de z. g. n. Tugutil aan. Deze heeten met de Tobeloreezen oorspronkelijk één stam uitgemaakt te hebben, maar zich, na het verhuizen naar de kust weer te hebben teruggetrokken naar het binnenland. Het verschil in ontwikkeling tusschen een strand-Tobelorees en een Tugutil, is echter heden ook aanzienlijk. Meer dan de erkenning van het ontwikkelende van het aan de kust wonén, zullen we 
dan ook wel niet uit al deze verhalen omtrent de woestheid en domheid van het voorgeslacht mogen afleiden.

Het verdient $\mathrm{m}$. i. de aandacht, dat in beide verhalen omtrent den uittocht, de Sangadji van Gamkonora genoemd wordt, als degene, die tot den uittocht den stoot gaf, en ook dat, hoewel verschillende namen opgegeven worden, in beide een jachtpartij van dezen gebieder, de eerste aanleiding tot de kennismaking was. $\mathrm{Nu}$ is het echter, naar mijn meening, niet zoo heel onwaarschijnlijk, dat de lui in het binnenland, door den beheerscher van Gamkonora onderdrukt werden, en daarom naar de kust trokken, om zich hieraan te ontrekken. In het binnenland toch is de woonplaats dicht bij het gebied van Gamkonora geweest, en dat de Sangadji van Gamkonora vandaar de lieden naar een kust zou brengen zóó ver van Gamkonora afgelegen als Tobelo, is niet waarschijnlijk. Het zal dan zóó geweest zijn, dat men aan de kust ook voorloopig nog niet heelemaal aan den invloed van Gamkonora ontkwam, maar zich toch op den duur daarvan wist vrij te maken.

Dat lost dan ook het raadsel op, hoe deze domme binnenlanders, zoo spoedig drieste zeeroovers werden. Ze kunnen dan n.l. door Gamkonora's vorst, met het bevaren der zee bekend geraakt zijn, zoodat diens overheersching, op die manier nog weldadig voor hen werd.

Zeker is, dat èn bij de Tobeloreezen, èn bij de Galelareezen (volgens van Baarda) nog allerlei verhalen in omloop zijn, omtrent een Sangadji van Gamkonora, met wien ze op zeeroof uitgingen, en die wondermacht bezat. Hij kon den wind stillen, en, had men gebrek aan zoet water, dan legde hij een rotan ring op de zee, en daarbinnen was het water zoet.

$\mathrm{Nu}$ geeft Willer op, dat in de $15^{\circ}$ eeuw Galela en Tobelo groote dorpen waren met zelfbestuur, doch afhankelijk van den Sangadji van Gamkonora. Volgens Tiele ging in 1544 de Portugeesche bevelhebber naar Moro, en ondersteunde den Sangadji van Gamkonora, die Galela veroveren wilde, 't geen ook met hulp der Portugeezen gelukte. Deze Sangadji, Liliato geheeten, was een vazal van Ternate.

Dat dus eenmaal de Sangadjis van Gamkonora macht uitgeoefend hebben in de Kaubaai, staat hierdoor historisch vast.

$\mathrm{Nu}$ nog de vraag: wanneer hebben de Tobeloreesche stammen zich aan de kust gevestigd? Hoort men de lieden ervan praten, Dl. 77. 
dan zou men zeggen: het is nog niet lang geleden, het feit ligt nog tamelijk versch in het geheugen. Men heeft zelfs nog voorwerpen, die uit het binnenland meegebracht zijn. Te Kupa-kupa zag ik een blauw porceleinen kom, en in de kampong Pitu toonde men mij een draagmand, waarin eenige pijlspitsen, en een paar gegleufde bamboelatjes om vuur te maken (o na ueto). Men gaf echter toe, dat het vlechtwerk van de draagmand, wel eens vernieuwd geworden was.

In verband met de overlevering onder de Kausche Tobeloreezen zou men zeggen, dat het al veel langer geleden is, want deze overlevering wijst op de zestiende eeuw. - Denkt men nu aan de verhalen omtrent het ontstaan der meeren van Gura en Patja, die wijzen op een verhoogde vulcanische werking in den bodem, en vergelijkt daarmede dat volgens Tiele, III ${ }^{e}$ deel, naar het verhaal van den Jesuiten-zendeling Jao de Beira, tijdens de uitbarsting van den Dukono in 1551, het water in het meer van Galela drie vademen rees, en het volksverhaal dat, toen de Tobeloreezen voor het eerst de kust trachtten te bereiken door het dal van de rivier Mèdee, de grond daar (in het afvloeingsgebied van den Dukono) te slecht was zoodat hij weerom keerde, dan brengt dat alles in 't midden der zestiende eeuw, en het zal wellicht niet al te gewaagd schijnen, de uittocht in dien tijd te stellen. Dat dan de aankomst op Halmahera, en aan het meer van Lina nog heel wat eerder valt, is duidelijk.

Wat betreft Willers mededeeling, dat reeds in de vijftiende eeuw Galela en Tobelo groote dorpen waren met zelfbestuur, afhankelijk van Gamkonora, is het wel mogelijk dat dit dorp Tobelo, niet aan de kust lag, maar in het binnenland.

Van af de vestiging aan het strand, tot het begin der $19^{\circ}$ eeuw, is mij van de geschiedenis der Tobeloreezen niets bekend. Misschien zou de kroniek van Ternate hieromtrent wat kunnen vertellen, want dat dit gedeelte van Halmahera in de $17^{\circ}$ en $18^{\mathrm{e}}$ eeuw onder Ternate stond, is wel zeker. Voor de O. I. Compagnie had het echter geen belang. Men leest wel van de districten Yatani, Weda en Maba op Oost-Halmahera, maar niet van N. Halmahera. Dit is ook niet te verwonderen. In de genoemde districten toch komen muskaatnootboomen voor, maar op N. Halmahera niet. Ergo behoefde men daar ook niet te vreezen voor vreemde indringers, dus had het ook geen belang, en vandaar het zwijgen. 
In het laatst der $18^{\mathrm{e}}$, en in het begin der $19^{\mathrm{e}}$ eeuw, moet men echter m. i. zoeken den grond, van wat ik maar kortweg zal noemen de "Djailolo sage».

Men vindt onder de Tobeloreezen een sterk verlangen naar de heerschappij van den koning van Djailolo "ma Koano Djailo». Komt men met 't een of ander bij hen aan, dan is het al heel gauw: Krijgen we dan ook onzen koning Djailolo terug? Vroeger maakten allerlei bedriegers er gebruik van zich uit te geven voor dien koning, of zijn plaatsvervanger of afgezant, om zich op kosten van de bevolking te verrijken.

Dit heeft de meening doen ingang vinden, dat dit nog steeds de invloed moet zijn van het vroegere Djailolo, het koningschap op Halmahera zelf. Daar is in de geschiedenis echter weinig grond voor te vinden. In de oudste tijden waarvan wij berichten hebben, treffen we vier Moluksche vorsten aan, n.l. Ternate, Tidore, Batjan en Djailolo. Het vorstendom Djailolo heeft dan een gebied op Halmahera zelf, maar volstrekt niet geheel Halmahera, zelfs niet het geheele Noordelijke schiereiland, want daar treft men Moro aan en Tolo, en op de W.-kust Gamkonora. Dat die rijken onderworpen waren aan Djailolo blijkt nergens uit. In de $17^{\mathrm{e}}$ eeuw heeft dit echter een eind gehad, en Djailolo is toen een deel geworden van het Sultanaat Ternate, vermoedelijk wel als gevolg van een huwelijk, hoewel de gegevens niet heel duidelijk zijn. Vast staat, dat het rijk niet onderging door krijg met Ternate, maar op min of meer vreedzame wijze daarbij gevoegd werd. De omliggende landen zullen toen wel al aan Ternate onderworpen geweest zijn, en Djailolo heeft toen geen groote rol meer gespeeld.

$\mathrm{Nu}$ geef ik eerst een tweetal verhalen, zooals die mij door de bevolking medegedeeld zijn, om hun vereering voor den koning van Djailolo begrijpelijk te maken. Het eerste is van een Kauschen Tobelorees.

Wij waren al van vroeger af onderdanen van den koning van Djailolo, maar dezen werd het lastig gemaakt door de koningen van Ternate en Tidore, zoodat hij vluchtte met de Tobeloreezen, dat waren zijn eigenlijke onderdanen. $Z \mathrm{ij}$ gingen aan wal te Gamkonora. Daar bleef de oudste Broeder van den koning Sangadji (districtshoofd), en men vluchtte verder naar het binnenland, en bleef aan het meer van Lina, en vandaar vluchtte men naar het strand. Hier en daar zijn nog kleine stukken metsel- 
werk welke als overblijfselen van dien tocht worden beschouwd.

De Tobeloreezen kwamen te Patja. Daar zette de Koning van Djailolo zijn stok, en men veegde om dien stok heen, zoodat de Ternatanen zeiden: patja, patja goraki (het vuil is al opgeveegd). Van het strand vluchtten de Kausche Tobeloreezen met den Radja van Djailolo naar Ceram, en vandaar werden zij door de Compagnie teruggebracht. Wij wachten nog steeds den Radja van Djailolo terug, en dachten dat Hassan het was, waarom wij ons ook allemaal bij hem aansloten.

Het andere verhaal, door een eigenlijke Tobelorees gedaan, luidt :

Pogu-poguru, Handiki en Rako bouwden Kupa-kupa. - Dit Kupa-kupa is nu een dorp in het Tobelosche, maar van eenig overblijfsel van een vroeger gebouw daar, is mij niets bekend. - Na vijf jaren hoorden de Ternatanen dat, en riepen Pogupoguru naar Ternate, om daar ook zulk een huis te bouwen. Hij weigerde dat echter, waarop de Ternatanen het huis te Kupa-kupa verbrandden. Daarop gingen de lui met den Koning van Djailolo mee naar Ceram. Zij maakten een fort te Hawai (Sawai) zoodat de vijanden het in zeven jaar nog niet konden veroveren. Toen kwam een schip en haalde den koning van Djailolo weg, en het volk werd zeeroovers te Tolalaki, (dit moet te Toboengkoe zijn op Celebes, hoewel ik die plaats niet juist weet).

Tot zoover de verhalen, of liever volksherinneringen.

Deze verhalen nu brengen ons in het begin der $19^{e}$ of het eind der $18^{\circ}$ eeuw. Vast te stellen valt wel, dat de Tobeloreezen al vroeger een woel-ziek volkje geweest zijn, die zich niet dan noode onder het Ternataansche juk gebogen hebben, zwervers en zeeschuimers, die een tamelijk ongeregeld leven leidden. Daar heeft echter Djailolo wel niets meer mee uitstaande gehad. Echter toen de Tidoreesche Prins Noekoe, na bijna een twintig jaar der Compagnie het hoofd geboden te hebben, het grootste deel van het Tidoreesche rijk onder zijn macht gebracht had, beklom hij in het laatst der $18^{\mathrm{e}}$ eeuw den Tidoreeschen troon, en haalde nu om èn de Compagnie, èn zijn vijand Ternate een genoegen te doen, de aardigheid uit, een Hoofd van het eiland Makian, tot Koning van Djailolo aan te stellen, in 1798. Zooals die slimme vos uitgerekend had, gebeurde het, de naam was op Halmahera bekend, de antipathie van de Tobeloreezen tegen 
Ternate eveneens, en de nieuwbakken Koning van Djailolo heeft dan ook onder hen spoedig veel aanhang gekregen, waartoe wel meegewerkt zal hebben dat al een groot aantal hunner, als roovers of krijgstroepen, in dienst van Noekoe waren. Immers reeds in 1795 had deze aanhang onder de Tobeloreezen, ja zelfs wel 1000 zouden hem gevolgd zijn.

Dien Koning van Djailolo tot rede te brengen, heeft aan de Compagnie heel wat moeite gekost, en in het begin van dezen strijd, zoolang het nog om Halmahera zelf ging, is steeds Ternate de voorvechter van de Compagnie geweest, daar Ternate het meeste te verliezen had, wijl het nieuwe rijk van Djailolo ter zijnen kosten gesticht moest worden. Daarvan zal wel voor een groot deel de latere haat van de Tobeloreezen tegen Ternate het gevolg geweest zijn.

In 1803 eischte Noekoe onder de vredesvoorwaarden met de Compagnie en Ternate ook dat Halmahera afgestaan zou worden aan den Koning van Djailolo. Hoewel dat nu niet ging, besloot men toch hem Kajasa, ten Zuiden van Dodinga af te staan, waarmede hij maar zeer noode genoegen nam. Ingeval hij daar vreedzaam bleef wonen, zou hij zeshonderd rijksdaalders ontvangen. Hij had zes maanden tijd om dien eisch te overwegen, maar begon al spoedig weer als vroeger, d.w.z. als een brutale roover op te treden, en in 1804 heeft hij de Tobeloreezen van Batjan gehaald, om met hen Dodinga te overvallen, 't geen evenwel nog tijdig belet werd. Daar hij niet ophield Ternataansche prauwen aan te vallen, werd er een expeditie tegen hem uitgerust, die bij Oba slaags met hem raakte, maar zonder gevolg. In hetzelfde jaar verscheen hij met een Tidoreesche kruisprauw voor Galela en Kau. Hij eischte daar onderwerping en staking van den toevoer van levensmiddelen naar Ternate.

De Galelareezen wierpen zijn brief weg, waarin hij onderwerping eischte, en die van Kau joegen hem weg. Spoedig echter kwam hij met groote macht terug, en bezette de rivier van Kau. Hij wilde, volgens Noekoe, voor zichzelf een koninkrijk veroveren, en men moest hem maar laten begaan, hij had het niet tegen de Compagnie, maar tegen Ternate.

In 1805 vroeg hij, in een request, hem, inplaats van geheel Halmahera, alleen maar het eigenlijke Djailolo af te staan.

In 1806, toen Noekoe dood was, en zijn opvolger Djanalabdin, door de Compagnie als Sultan van Tidore moest erkend worden, 
wilde men dat niet doen, dan onder voorwaarde, dat hij den koning van Djailolo eerst zou uitleveren. Hij wilde dit ook gaarne doen, maar helaas, die koning was nu gevlucht. Men had hem achtervolgd, doch zonder vrucht. Hij trachtte in December 1806 zich meester te maken van het eiland Tidore, maar werd door de Ternatanen verslagen, en vluchtte de bosschen in, wist een prauw machtig te worden, en ging daarmede naar Patani, waar hij nog in dezelfde maand aan de gevolgen van een val overleed.

Hiermede was het echter niet uit, want hij had zonen en opvolgers en een van die werd door de Mangindanausche zeeroovers en de Tobeloreezen die op Kobe (Z.kust van het $\mathrm{O}$. schiereiland) waren, tot koning aangesteld. Toen in 1809 een gezantschap uitgezonden werd om den Tidoreeschen Prins Mossel te bewegen van Ceram naar Ambon te gaan, durfde deze dat niet te wagen, omdat vier zoons van den koning van Djailolo met 700 Tobeloreezen op den loer lagen.

In 1811 tijdens het Engelsche tusschenbestuur, werd deze koning van Djailolo, Asgar of Ngofa Djou geheeten, gevangen genomen, en naar Ambon gebracht. Na de overneming van het bewind door het Hollandsche Bestuur, werd hij in 1818 overgebracht naar Java, doch een van zijn broeders werd koning van Djailolo en deze bracht in 1819 een groot gedeelte van de kust van N. Guinea, en de Papoesche eilanden, met Ceram en de Oostkust van Halmahera in opstand. Na velerlei rooverijen werd hem op de Noordkust van Ceram een groote nederlaag toegebracht in 1823 , waarop door het Gouvernement te Sawai, op Cerams Noordkust, een vesting gebouwd werd. In 1824 werden met dezen koning onderhandelingen aangeknoopt, en hij eischte erkend te worden als $4^{e}$ Moluksche koning, waarna een gedeelte van de Noordkust van Ceram aan hem en zijn volgelingen werd toegewezen. Doch deze volgelingen begeerden nu niet hem, maar zijn naar Java gevoerde broeder Asgar, tot koning. Deze kwam dan ook terug, en werd als Vorst erkend in 1825, maar helaas, dit alles baatte niet, men bleef zich schuldig maken aan zeerooverijen en om daar een eind aan te maken, werd de heele Sultansfamilie in 1832 weer naar Java gebracht, en het Sultanaat Djailolo op Ceram voorgoed opgeheven.

Het is nu niet moeilijk om in dat alles de geschiedenissen, die men onder de Tobeloreezen verhaalt, hier en daar in dit avontuurlijke tijdperk te plaatsen. 
De Tobeloreezen werden nu naar hun land teruggebracht, maar men begrijpt, dat zij niet meer geschikt waren voor een rustige levenswijze, en dus begon toen wat het eene verhaal zegt: toen werden ze zeeroovers te Tolalaki.

Een broeder van koning Asgar was Hoofd der Magindanausche zeeroovers geworden. Deze periode heeft wel een 50 jaar geduurd. Elk oogenblik traden ze brutaal op, en maakten de heele Molukken onveilig.

Tot zelfs in het Ambonsche waren ze gevreesd.

Er werd wel steeds tegen hen opgetreden, maar zonder gunstig gevolg. Bij een dier expedities werd in 1855 Tobelo, d. w. z. de toenmalige vestiging, in brand geschoten, en de bevolking verplaatst naar de tegenwoordige hoofdvestiging Gamhungi.

Toen in 1878 het beruchte Hoofd Madon gevangen genomen werd, begon men weer naar Tobelo terug te keeren. Het eigenlijke rooven is echter uitgeraakt, sinds het Gouvernement met stoomschepen begon te varen.

Hoewel men ook aanvankelijk een groote vijandschap had tegen het Gouvernement, omdat dat conzen koning van Djailolo» weggevoerd had, is daar nu niets meer van overgebleven, maar antipathie tegen Ternate heeft men nog wel. Natuurlijk is dit, omdat men met den koning van Djailolo steeds tegen Ternate gevochten heeft.

Toen in 1876 Danoe-Hassan optrad, met de pretentie koning van Djailolo te zijn, had hij dadelijk al de Tobeloreesche roovers met zich, 't welk wel hoofdzakelijk aan de haat tegen Ternate geweten moet worden.

En de wensch naar terugkeer van den koning van Djailolo berust natuurlijk op de tegenstelling: een vrij rooversleven leiden, of wel ordelijk wonen. De oude verhalen omtrent gepleegde heldendaden onder den koning van Djailolo hielden vanzelf nog lang de gemoederen warm.

Nà het regeeren van Hangadji Madon, kwam daar nog bij het streven van Ternate, om het ambt Hangadji, districtshoofd, in Mohamedaansche handen te brengen, waartegen het volk zich algemeen verzette.

De dreigende opstand in 1897-98, ten gevolge waarvan de christianisatie ontstond, werd door dat streven veroorzaakt.

$\mathrm{Na}$ de christianisatie heeft het Binnenlandsch Bestuur zich meer met de zaken ingelaten, en reeds lang voor den val van het 
Sultanaat Ternate in 1914, was de Ternataansche invloed in Tobelo zoo goed als verdwenen, hoewel dat natuurlijk door de daar gevestigde Ternatanen met leede oogen aangezien werd.

\section{HOOFDSTUK 5.}

\section{Volksaard en karakter.}

De Tobeloreezen zijn zwerfzuchtig, zij verplaatsen zich heel gemakkelijk en wanneer zij zich verongelijkt achten, is hun eerste uiting: dan ga ik weg! Men kan dit natuurlijk wel vrijheidszucht noemen, maar het ontaardt nogal in bandeloosheid, en maakt het moeilijk hen te besturen, zelfs voor hunne adat-hoofden. Men mag deze hoofden niet openlijk wederstaan, maar zich aan hun bevelen onttrekken, door heen te gaan is volstrekt niet verboden. Bevelen doen de hoofden dan ook niet, maar zij overreden, higaro, zoo men dat zegt. Een Hoofd dat veel invloed heeft, weet te higaro, te overreden, zoodat men gaarne doet wat hij zegt.

Een Europeesch ambtenaar maakt zich natuurlijk boos, wanneer het een of ander Hoofd iets niet weet gedaan te krijgen, maar dat is toch eigenlijk ten onrechte, want het gezag van het Hoofd hoủdt op, zoodra hij met de een of andere nieuwigheid aankomt. Weet hij door een praatje het nieuwe smakelijk te maken, dan is het goed, maar zoo niet, dan is al zijn invloed niet in staat het een of ander tot stand te brengen, waar zijn volk tegen is. Van standverschil tusschen Hoofden en minderen is dan ook geen sprake. Het is de zuiverste democratie die men zich denken kan. Een Hoofd heeft ook geen volgelingen, hij is de eerste onder zijns gelijken, en als er onder de gelijken één is die beter weet te praten dan hij, heeft hij nog heel veel kans ook het eerste zijn, in te boeten.

Op een vreemde plaats houdt natuurlijk het onderling belang de menschen wel bij elkaar, en zelfs min of meer in toom.

$\mathrm{Nu}$ is die zucht om gelijk te hebben, om te doen precies wat men wil, voor buren juist niet aangenaam, en de Tobeloreezen zijn dan ook volstrekt geen aangename buren, want, zooals het gewoonlijk gaat, ofschoon ze zelf willen doen wat ze willen, wenschen zij dat toch niet aan anderen toe te staan.

In het eigen land nu, kan men bij tegenwerking weg trekken, 
maar onder vreemden heeft men niet die plicht tot hoffelijkheid, en maakt men zich dus met de ellebogen ruimte. M. a. w. de Tobelorees is dan een zeer gewelddadig heer, en die eigenschap heeft ten gevolge, dat men hem al spoedig liever alleen laat wonen, en daardoor breidt het door hen bewoonde gebied zich steeds uit.

$\mathrm{Hij}$ is ook over het geheel volstrekt niet beleefd, wel het tegendeel. Hij heeft wel een adat, o zeker wel, maar handelt er toch dikwerf niet naar. Hij is ruw, en zegt heel kalm wat hem in den zin komt, ook al is dat heel kwetsend voor een ander. Ja hij is zelfs dikwijls met opzet heel beleedigend en grof.

Dat zijn nu juist geen aangename eigenschappen, vooral niet als men daar nog bijvoegt, een koppigheid en stijfhoofdigheid, die soms haast aan het ongelooflijke grenst.

Maar, hij heeft ook goede eigenschappen, waardoor zelfs de onaangename nog al sterk geneutraliseerd worden.

Hij is nogal oprecht! Zegt hij iets, dan kan men wel gelooven dat hij het meent. Ook is hij over het geheel geen weerhaan! Heeft men zijn vertrouwen dan heeft men dat ook geheel, en men kan wel op hem aan. $Z_{\text {ijn }}$ verstandelijke vermogens laten niets te wenschen over. Hij kan over het geheel "goed leeren». Ook is hij niet van natuurlijk overleg ontbloot, en weet een toestand nog al spoedig juist te beoordeelen.

Neemt men nu deze goede eigenschappen met de vorige, dan krijgt men ruwe kerels, maar waar toch heel goed wat mee te beginnen is. 't $Z i j n$ geen zoutzakken. $Z e$ staan op hun plaats, en weten zich daar te handhaven.

Met zulk een volk is wel wat aan te vangen. Hoogst koppig, maar daarom nog niet ontoegankelijk voor een verstandige redeneering. Hebben ze eenmaal iets als goed erkend, dan doen ze het gewoonlijk ook wel. Daarbij ondernemend, misschien niet ijverig in den zin dien wij aan dat woord hechten, maar toch ook niet zoozeer verslapt, dat zij niet tot iets goeds in staat zouden zijn. Men weet zich heel goed voor het een of ander doel in te spannen, en belangrijke bezwaren te overwinnen. Men maakt zeer groote tuinen en weet ijver wel te waardeeren. Natuurlijk dat ook hier wel bijkomt de hebzucht en de zucht om te pralen, om groot te doen. Iemand die zich door zijn ijver geld verzameld heeft, is gewoonlijk geldgierig. 's Avonds als alles stil is, vindt men het een uitgelezen genot, de kist te openen, 
en het geld door de vingers te laten glijden. Men pot heel gaarne, en geeft maar noode het geld uit. Kan men zooveel klein geld bij elkaar brengen, dat het om te zetten is in een rijksdaalder, dan is het zeer moeilijk om dien rijksdaalder weer klein te maken. Ik heb gezien, dat men liever gebrek leed, dan het geld uit de kist te nemen om spijze te koopen. Kan men echter, bij gelegenheid van een huwelijk of zoo, met het geld pronken, dan geeft men het gaarne uit.

Ik zeide, dat men met het geld in de kist rammelt. Dat is ook zoo, wanneer men meent dat het daar veilig is voor dieven, maar, indien men wat ouder wordt, en de som wordt grooter, dan verbergt men het, door het hier of daar te begraven. En vooral ouden van dagen ontwikkelen zich dan tot de meest volmaakte gierigaards, die men zich maar denken kan. Zij sjouwen hun schat van de eene plek naar de andere, steeds zich bespied wanende. $\mathrm{Nu}$ is dat in den regel ook wel het geval, want de erfgenamen van zoo'n oude heer, loeren van alle kanten, om na te gaan waar hij het geld brengt. Maar de oude tracht hen steeds te ontloopen, en dikwijls gelukt dit ook wel. Soms kruipt zoo iemand, die zijn einde voelt naderen, 's nachts half dood nog naar zijn geld, om het weer ergens elders weg te stoppen, en de erfgenamen hebben nu alle kans niets te vinden. Aanzienlijke sommen gaan op die manier verloren. Waarom men het eigenlijk doet is niet te begrijpen, want er is in hun denken niets wat aanduidt, dat het geld nog na hun dood voor hen van nut zijn zou. Het is dus niets dan onhebbelijke gierigheid, die de kinderen het bezit niet gunt, van wat men zelf toch niet meer behouden kan.

Over het geheel is men eerlijk, tenminste in groote zaken. Er zijn families die bepaald kleptomaan zijn, en daarom ook door ieder wel zoowat gemeden worden. Maar die uitgezonderd, heb ik wel treffende staaltjes van trouw gezien, om wat hen voor een ander meegegeven was ook over te brengen, hoewel men voor het niet overbrengen gemakkelijk een reden had kunnen vinden. Men vindt stelen heel min, en het geldt zelfs als reden voor echtscheiding.

Ook zegt men niet heel gauw een onwaarheid, maar zichzelf benadeelen door de volle waarheid mee te deelen, doet men toch maar liever niet. Wat voor eigen zaak nadeelig is, verzwijgt men. Ook vindt men het juist geen kwaad om onnoozlen met de 
malste geruchten voor den gek te houden, en daardoor veel verwarring te stichten.

Dat men over het geheel ruw is, blijkt ook wel vooral uit de spreektaal. Men gebruikt de vuilste scheldwoorden, zonder ér bij te denken zelfs.

Niet, alsof schelden op zichzelf geoorloofd zou zijn, dat niet, het is zelfs strafbaar, en tegenover vreemden wacht men zich ook wel, maar in 't gezin, b.v. de taal van sommige ouders tegen hun kinderen is schandelijk! Men hoort een moeder heel kalm tegen haar kind zeggen: he tjuki-ajo ma ngohaka= "wel kind verwekt in bloedschande met iemands moeder », en dergelijke uitdrukkingen meer.

Men zweert bij het minste geringste, bij God, of ook wel: o totaleo ho toaka, met welke min of meer abrupte uitdrukking men zeggen wil: ik snijd een kip de kop af, zoo min die weer levend wordt, zoo min lieg ik. Natuurlijk dat men zich dat evenmin bewust is in den gewonen regel, als een Hollandsche vloeker de kracht van zijn verwenschingen voelt. Men is maar eenvoudig gewoon ruwe taal uit te slaan.

Men is niet bepaald twistziek, en al komt er soms om een kleinigheid een hevige woordenwisseling, men moet dat niet al te hoog aanslaan, men meent het zoo erg niet. Een oogenblik daarna gaat men weer vreedzaam met elkaar om. Tot bepaalde vechterijen komt men zelden, zelfs niet in een palmwijnroes. Want natuurlijk, een volk met zooveel feesten als de Tobeloreezen, is nogal sterk overgegeven aan het genot van palmwijn. Men wordt daardoor hoogst vervelend voor een derde, wat grootsprekerig, kletserig, maar men wordt toch niet twistziek, eerder sentimenteel. Twistziek wordt men wel door het gebruik van jenever. Dat is als gif in de menschen. Het komt wel hierdoor, dat ze het bij bierglazen drinken, als ze het krijgen kunnen, maar het maakt ze dan ook werkelijk dol. Was op een feest jenever, dan liep het zelden zonder ernstige kloppartijen af. Maar dat niet het geval zijnde, is er wel veel geschreeuw soms, maar tot ernstige vechterijen komt het niet.

Ten opzichte der zindelijkheid is er groot verschil tusschen strandbewoners, en hen die meer in het bosch vertoeven. Strandbewoners baden zich geregeld. Na terugkeer uit de tuinen, gaat elk naar de badplaats, gewoonlijk de vrouwen 't eerst. Een schoone sarong wordt steeds meegenomen, en na het bad aangetrokken, 
waarna men de gebruikte ultwascht. Dat wasschen is natuurlijk niet zoo grondig als dat in een waschinrichting gebeurt, maar het is dan toch weer schoon.

Boschbewoners baden niet zoo geregeld, maar als die dan ook met strandbewoners verkeeren, hoort men al heel gauw: dat is een vuile kerel, die stinkt, want hij weet zich niet te baden.

In de badplaats heerscht orde. De twee geslachten baden niet gezamenlijk. Elk die een badplaats nadert, op welk uur van den dag ook, roept eerst. Is de bader van 't zelfde geslacht als de roeper, dan mag men passeeren, in 't tegenovergestelde geval moet men wachten. Moet men al een badende vrouw passeeren, dan eischt de adat dat men het hoofd afwendt, en tevens van dat feit kennis geeft door te roepen: ik draai mijn hoofd om hoor! Te kijken naar een naakte vrouw zou wel het toppunt van onopgevoedheid wezen, en is bovendien strafbaar.

Men heeft natuurlijk hoofd-, ook wel kleerluizen. Elkaar luizen is een vriendschapsdienst. De vrouw doet het ook haar man, hoewel ik het nooit omgekeerd zag doen. Vrouwen luisden altijd elkaar. Evenwel, ook hierin is een grens. Iemand die altijd onder de luizen zit, wordt door iedereen geminacht. Zoo ook met wandluizen in de woningen. Ik geloof niet, dat éen woning of slaapplaats daar vrij van is, maar het mag ook weer niet al te wezen, want dat geldt als een teeken van luiheid en vuilheid. Een fatsoenlijk mensch legt zijn slaapmat in de zon, en klopt zijn slaapbank eens uit, als hij wat al te veel gezelschap krijgt des nachts.

Medelijden met ongelukkigen kent men niet veel; men kan zelfs heel wreed zijn, om zich te ontdoen van iemand die men minderwaardig vindt. Een staaltje daarvan is bv. dit: In zekere familie waren doofstomme kinderen. Men vondt dit nogal lastig. Op zekeren dag, toen de heele kampong, met een der doofstommen, een forsche kerel, bezig was op een rif, bijna een uur uit den wal gelegen, visch te zoeken, ging men stilletjes in de prauwen en roeide weg, zonder den doofstommen te verwittigen. Natuurlijk zou de stumpert bij het opkomen van het water nu ellendig. moeten verdrinken, maar men was dan van hem af. Het viel echter niet mee, want de man bemerkende wat er gebeurd was, sprong in zee en zwom naar den vasten wal die hij ook, hoewel half dood, bereikte. Dat een zeerooversbevolking nogal wreed is, ligt in den aard der zaak, maar daarom behoeft men het onder elkander nog niet te zijn. 
Er werden mij ook verschillende staaltjes medegedeeld van wreedheden, die vroeger sommigen zich tegenover hun slaven veroorloofden, hoewel over het geheel die slaven het zoo kwaad niet hadden, en als een soort mindere familieleden werden beschouwd. Ik heb er gekend, die ook na hun vrijkoop door het Gouvernement, heel kalm bij de familie gebleven waren, en nog steeds als behoorende tot de familie, behandeld werden. Maar natuurlijk, was de meester ruw, dan was daar ook niets tegen te doen.

Men is over het geheel nogal opgewekt van aard, en neemt het leven niet van den zwaren kant. Tusschen de Kausche Tobeloreezen en de anderen is ten dezen opzichte nog wel verschil, aangezien de eersten, niet opgewekter, maar wel veel luidruchtiger zijn, dan de Tobeloreezen zelf. Bij het minste geringste maken die een leven, dat men er doof van wordt, ook zijn ze wat meer grootsprekerig dan de anderen.

Over het geheel is de Tobelorees wat men noemt: geen kwade kerel, maar men moet weten met hem om te gaan.

\section{HOOFDSTUK 6.}

\section{Voorkomen en kleeding.}

De Tobelorees is tamelijk flink gebouwd. Men ziet onder hen kloeke gestalten, flink gespierd, van een aangenaam voorkomen. Niet weinigen neigen op lateren leeftijd tot zwaarlijvigheid.

Men heeft ook een aantal magere gestalten hoewel ook flink gebouwd. Dezen onderscheiden zich ook door krullend haar, terwijl de anderen (de meesten) sluik of glad haar hebben. Volgens sommigen zijn die magere gestalten, krulharig, de echte Tobeloreezen. Ik kan dat niet uitmaken, maar in vergelijking met de Galelareezen bv. zou ik denken dat men ongelijk heeft, en dat die magere krulharige menschen, die ook wat donkerder van kleur zijn, wel ontstaan kunnen zijn door vermenging met andere rassen, misschien met Papoea's. Zelfs in hun karakter hebben die lui wat aparts. Ze zijn zeker meer stijfhoofdig nog, dan de rest, en ik zou zeggen, minder goed verstandelijk aangelegd.

De Kausche Tobelo is ook wat slanker dan de Tobelorees zelf. Het gelaat heeft een verstandige uitdrukking, de neus is bij 
sommigen Kaukasisch bijna. Een enkele doet, door een eenigszins gebogen neus aan Arabieren denken. De huidkleur is lichtbruin, met variatie natuurlijk, maar hoe lichter, hoe mooier men het vindt.

Veel mannen hebben een sterke baardgroei, en velen laten den baard groeien ook. Men ziet mannen met werkelijk fraaie baarden. Ook knevels draagt men gaarne. Het haar wordt ook door de mannen lang gedragen en in een wrong op zijde van het hoofd opgebonden, waar omheen men dan de hoofddoek windt. Het lichaam is nogal behaard, vooral bij 't mannelijk geslacht, de beenen. Sommigen brengen zelfs in die huidharen op de beenen figuren aan, of door het op bosjes te laten groeien, of door het in ringen weg te scheren. De vrouwen zijn over het geheel iets kleiner dan de mannen, maar toch ook flink gebouwd. Het vrouwelijk gelaat is bij velen volstrekt niet onbevallig, zelfs bij bejaarde vrouwen niet.

Het gebit is sterk, en houdt zich bij sommigen tot zelfs in hoge ouderdom goed, maar men ziet ook vele bejaarde lieden met een soort houten bekertjes en een stampertje loopen om hun sirih-pinang fijn te stampen, omdat ze die niet meer kunnen kauwen.

Het gezicht is heel goed, hoewel de meesten, tengevolge van hun op zee zijn, natuurlijk verziende worden. Het is verbazend op hoe verren afstand de menschen iets heel duidelijk weten te onderscheiden. Wel komen nogal epidemische oogziekten voor, maar die hebben toch zelden op den duur ernstige gevolgen. Blinden ziet men niet veel.

Het gehoor is normaal ontwikkeld, hoewel natuurlijk jagers dat beter ontwikkeld hebben dan visschers.

De vrouwelijke borsten ziet men in allerlei vormen, bij de meeste vrouwen echter zeer goed ontwikkeld, hoewel niet monsterachtig. Daar echter heel veel vrouwen bij het zoogen slechts één borst gebruiken, en daardoor de andere klier minder ontwikkeld is geeft dat iets onregelmatigs aan de gestalte.

Albino's komen voor, hoewel juist niet heel frequent. Men vindt albino-vrouwen wel mooi, maar heeft toch angst om ze te trouwen, met het oog op hun gezichtsvermogen, dat vooral bij ouderen, overdag al heel gering is. De huid dezer albino's is, hoewel blank, toch heel grof, en voor Europeesch oog, al heel onsmakelijk. 
Men tatoueert zich niet.

De kleeding heeft oorspronkelijk voor de mannen alleen bestaan uit een hoofddoek en een schaamtegordel, en voor de vrouwen uit een korte sarong, natuurlijk alles van boombast.

$\mathrm{Nu}$ draagt men meer kleeding natuurlijk, de mannen broek en baadje, hoewel toch ook nog dikwerf bij 't werk in de tuinen alleen de schaamtegordel gedragen wordt, en men zich daarmede volstrekt niet ongekleed gevoelt. De vrouwen dragen nu ook een kabaja met een sarong. De sarong slaat men dwars om, zoodat op, ik meen het linkerbeen, de vouw komt. Daar men hem bovendien natuurlijk op die wijze heel kort draagt, is de beweging der beenen er volstrekt niet door belemmerd, want het kleed komt even over de knie, en wijkt zijdelings gemakkelijk uit elkaar. Dat is nu ook wel noodig bij het loopen over de smalle paadjes, tusschen het hooge alang-alang gras, waarbij men met een lang hangende sarong allicht struikelen zou. Alleen maar, als zulk een vrouw in haar geliefkoosde houding, dat is hurkend, nederzit, komt er wel eens wat al te veel van haar lichaam bloot. Op feesten draagt men dan ook de sarong veel langer. Ook dragen de vrouwen, volgens de oude manier, geen kabaja, maar over het bovenlijf, losjes over de borsten geslagen, een tweede sarong, die men onder de armen vasthoudt. De rug blijft daarbij onbedekt, en het schijnt wel, dat jonge dochters deze dracht nogal prefereeren, omdat de gelegenheid mooi is, een beetje met haar borsten te coquetteeren. Ook wel vervangt men die tweede sarong door een rood doekje, ter grootte van een zakdoek, o gugugia, om daarmede de borsten te bedekken. Het hoofd blijft bij de vrouwen onbedekt; mannen die op reis gaan, hebben een hoed bij zich, gewoonlijk door hun vrouwen gemaakt, van breede biezen in elkaar genaaid, en van boven rood of geel gekleurd, ook wel beide kleuren door elkaar, en fraai versierd met kleine witte kraaltjes. Vroeger gebruikte men voor die versieringen een soort schelpjes, maar daar die in 't district Tobelo zelf niet voorkomen, schijnt men zich al vroeg van de witte kraaltjes bediend te hebben. Visschers gebruiken in den regel een grover soort hoed.

Beide geslachten hebben gewoonlijk gaatjes in de ooren, waarin men gaarne allerlei bloempjes steekt, en de meisjes bovendien oorhangers, o ta ù g e, en knopjes: o $\mathrm{k} \mathrm{a} \mathrm{r} \mathrm{a} \mathrm{b} \mathrm{u,} \mathrm{zilveren}$ en gouden. 
Ook in de haarwrong steekt men bloemen, vooral op feesten. Beide geslachten dragen in de haarwrong gaarne kammen, schildpadden, met hoog opstaande hoornen, o ekoro, en de vrouwen ook allerlei haarspelden.

Aan de vingers draagt men gaarne ringen, zilveren, met onmogelijk groote steenen, ook wel van schildpad gesnedene, of andere zonderlinge ringen. - De mannen dragen om den bovenarm gevlochten ringen van arenvezels, met kraaltjes versierd, en om de benedenarmen gaarne een ring van een soort zeegewas, o kalibaharu, waardoor de arm krachtig wordt.

De vrouwen, vooral jonge dochters, hebben de armen soms overladen met ringen, zoowel zilveren - enkel gouden - als uit schelpen gemaakte. Onder de laatsten sommigen heel fraai besneden. Men kent dè kunst om de schelpringen "o basane, te maken.

Bij de Kausche Tobeloreezen dragen de vrouwen ook enkelringen, koperen en zilveren, maar in Tobelo zelf is dat geen gewoonte. Voor feestkleeding heeft men allerlei gewaden. Lange fluweelen mantels, soms met goud en zilver afgezet, prachtige sarongs, voor de vrouwen allerlei zilveren hoofdversiersels enz.

Een stoet die naar een feest gaat, of zich voor het een of ander doel feestelijk gekleed heeft, is werkelijk soms een schitterend gezicht. Men lucht dan al zijn smaak voor kleur en schittering, en hoewel soms die smaak, volgens onze opvattingen grove wansmaak is, is toch het algemeen effect er niet minder om.

\section{HOOFDSTUK 7.}

\section{Algemeene beschouwingen over de denkwijze der Tobeloreezen omtrent geestelijke dingen.}

Ik laat deze algemeene beschouwingen voorafgaan aan de beschrijving der verschillende handelingen en ceremoniën, om niet later te moeten vervallen in zich telkens weer herhalende verklaringen, die dan ook telkens partiëel, en daardoor altijd onduidelijk moeten zijn. Heeft men eenmaal een begrip van de algemeene denkwijze, dan valt het niet moeilijk een en ander te begrijpen, en een korte verwijzing naar het vroeger gezegde is dan voldoende, om op te helderen wat duister mocht zijn. 
Het spreekt wel vanzelf, dat een beschouwing als deze, die alles systematisch tracht voor te stellen, niet aldus bij de Tobeloreezen zelf gevonden wordt. De Tobelorees is niet philosofisch aangelegd. Hij verricht zijn ceremoniën, en volgt zijn gewoonten, zonder daar veel bij te denken, ja, dikwerf, zonder ook maar in het minst te weten, waarom dit $z u s$, dat $z o o$ moet gebeuren. $\mathrm{Hij}_{\mathrm{ij}}$ systematiseert niet, en heeft daar ook al heel weinig behoefte aan. Logica is zijn zwak niet, en het is hem novit een behoefte voor zichzelf duidelijk te maken, of zijn eeredienst en gewoonten wel goed en logisch zijn. Ze komen toch overeen met zijn wijze van denken en dat is hem volkomen voldoende.

$W_{i j}$ zien nu wel een systeem, een gedachtengang in dit alles, maar ik geloof, dat het toch beslist foutief is, wanneer wij daaruit mochten willen besluiten, dat het als stelsel eenmaal aldus $g e$ dacht is.

Dit toch zou ons brengen tot de vraag: wie was degene, die voor het eerst dit alles dacht, m. a. w. wie was de stichter van dezen dienst, (godsdienst kan men het niet noemen), en zeker is zulk een stichter er evenmin ooit geweest, als wij hem kunnen aanwijzen in de historie. Deze dingen zijn geworden, gegroeid. Zooals een appelboom appels draagt, omdat hij een appelboom is, zoo draagt ook het soort denken van dit volk dit of een dergelijk systeem van eeredienst. Het animisme is nergens een logisch stelsel, zóó, dat een zijner aanhangers het ons zou kunnen voorleggen. Overal wordt het stelsel door ons gezien uit de verschillende ceremoniën, uit losse brokstukken eeredienst, uit verhalen en legenden. De hoofdgedachte is bij alle volken dezelfde, in details wijkt men van elkaar af. Het soort van denken was bij allen hetzelfde, en bracht dus ook allen tot gelijksoortige handelingen. - Wij hebben dus niet te denken aan een stichter van een animistischen cultus maar eenvoudig aan een algemeene aanleg, waaruit die voortgevloeid is.

Het animisme makkt op mij den indruk van een vergroofd, diep gezonken pantheïsme. Ik geloof dat men, langs de lijn van het pantheïsme doorgaande, de godsgedachte laat varen, en hier te recht komt.

$\mathrm{Nu}$ moet niet vergeten worden, dat op het oorspronkelijk denken van een volk als de Tobeloreezen, invloed uitgeoefend kan zijn, door volken of invloeden, waarmede het in aanraking gekomen is.

D1. 77. 
Ik denk hierbij aan het Mohamedanisme, dat wel nooit veel proselieten onder hen gemaakt heeft, maar toch onwillekeurig hier en daar wat heeft gewijzigd, bijgevoegd, opgeplakt soms.

Dit kan niet anders. Zelfs godsdiensten met beschreven eeredienst en wetten, ondergaan wijzigingen, wanneer zij met andere in aanraking komen, hoeveel te meer een cultus, die nooit door wetten of schrifturen begrensd was, maar alleen bestond als uitvloeisel van gemeenschappelijk denken.

Hier is nog bij op te merken, van hoe groot gewicht het is, dat een volk priesters heeft. Waar die zijn, houden zij gewoonlijk het overgeleverde denken vast, het is het hunne, hun speciaal toebetrouwd. Het volk bemoeit zich dan minder met den eeredienst, maar leeft bij wat de priesters doen.

Een gevolg daarvan is, dat iets nieuws gemakkelijk geweerd wordt en het oude een constanten vorm krijgt, ook al is het geen logisch systeem.

Een volk zonder priesters verkeert in geheel andere omstandigheden. Het denkt zelf. $Z_{\text {ijn }}$ cultus is het uitvloeisel van het algemeene denken, elk zorgt er voor. Daardoor staat eenerzijds alles zeer vast, maar bij het in aanraking komen met vreemde invloeden, komt het gevaar, dat ook elk wijzigend kan optreden. Elk heeft evenveel recht, niemand verdedigt het algemeene denken als zoodanig, en dus het gevolg, het noodzakelijk gevolg is, dat een volk zonder priesters gemakkelijk vreemde inmengsels in zijn oorspronkelijken eeredienst ziet invloeien. Dat dit ook bij de Tobeloreezen het geval geweest is, zullen wij gelegenheid hebben waar te nemen.

Nog moet ik opmerken, dat niet alle Tobeloreezen hetzelfde denken. Ook daarin is verschil. Het is waar, het volk is niet wijsgeerig, maar wel vindt men sommige fantasten onder hen. Men ontmoet soms lieden, die vooral tegenover een vreemden ondervrager, al heel wonderlijke gevoelens openbaren, gevoelens die niet in het minst overeenkomen met het algemeene denken. Gewoonlijk zijn dit lieden, die zich gaarne interessant maken, zich gaarne op den voorgrond stellen, doordien ze wat van de wereld gezien hebben, goed de Maleische taal machtig zijn, en dus in den regel als vraagbaak dienen, voor wie een enkele maal hier of daar komt, en onderzoekingen instelt. Op rekening hiervan moeten dan ook de allerwonderlijkste dingen gesteld worden, die door sommige ethnologen omtrent de Tobeloreezen 
verteld zijn. De normaal denkende Tobelorees openbaart niet zoo spoedig wat hij denkt; met moet al op heel vertrouwelijken voet met hem komen, eer hij zich eens laat gaan, en zegt wat $z i j n$ gevoelen is.

Nog heeft men soms een wonderlijke verwarring omtrent namen voor begrippen. Dit komt hierdoor, dat ook onder de Tobeloreezen gevonden worden domooren, lieden die niets weten dat hooger gaat dan eten, drinken en slapen, maar die toch ook soms mee moeten praten, en dan links rechts noemen en omgekeerd, juist als bij ons.

De Tobelorees is trigotomist. De mensch bestaat uit roæhe, gikiri of njawa en gurumini.

Het eerste woord geeft geen moeilijkheid, het beteekent eenvoudig "lichaam», de uiterlijke verschijning. Het woord wordt ook gebruikt om den stam van een boom, de steel van een plant etc. aan te duiden, en men verstaat er dus ook, omtrent den mensch gebruikt, niets anders onder dan het stoffelijk omhulsel. Het wordt gebruikt met het bezittelijk voornaamw. nanga = iemands, en dus nooit vereenzelvigd met de eigenlijke mensch. Men zegt: o njawa manga roěhe, het lichaam van een mensch, en bewijst daardoor, het lichaam niet met den mensch te vereenzelvigen.

Het tweede woord gikiri of $n j a w a$ levert reeds meer moeilijkheden op bij de vertaling. Het woord gikiri, in het Galelareesch $\mathrm{giki}$, in het Ternataansch evenzoo, is zeker het oudste, en dus het oorspronkelijkste. Het wordt nu nog in sommige uitdrukkingen, voor "mensch" gebruikt, b. v. b. in: o gikiri ma ago agomo de o hohumudjuro: aanzienlijken en geringen, en zal vroeger wel de gewone naam voor "mensch" geweest zijn. Het wordt nu ook nog wel als zoodanig heel enkel gebruikt, maar toch niet veel meer. De poezie is echter op dit punt nogal welsprekend. Meerendeels is die niet in het Tobeloreesch, maar in een mengelmoes van Ternataansch, Tidoreesch, Galelareesch en Tobeloreesch. Daarin wordt echter geregeld gesproken van iemand als van een giki. He giki moi ma ngopa: wel kind van iemand, van een mensch; giki laha: goede menschen, etc. Ook de naam van de dorpshoofden: ki ma laha (waarschijnlijk) afgekort van giki ma laha, de beste mensch, wijst op een vroeger gebruik van giki of gikiri voor "mensch". Nu zegt het Ternat. voor mensch: 
manoesia, het Galelar. en Tobelor. o njawa, maar beide Maleische woorden zijn kennelijk indringers.

Wat de grondbeteekenis is van het oude woord, dat in zijn oudsten vorm wel "gikir» geweest zal zijn, is moeilijk te zeggen. $N u$ beduidt bij de Tobeloreezen gikiri: levend wezen, zoowel stoffelijk als onstoffelijk. Men zegt van een mierennest, de ma gikiroka: er zijn mieren in, van een voorwerp, dat men met een geest behuisd denkt, heet het eveneens: de ma gikiroka, er is iets levends in, en van den mensch zegt men ook, dat hij is: de ma gikiroka, met leven, maar ook even goed, dat hij zelf is, een gikiri, een levend wezen. Het gebruik is dus nogal zwevend. Men kan spreken van o gikiri manga gikiri: de mensch zijn ...? Het eerste woord is dan natuurlijk »mensch», en het tweede zijn onstoffelijk bestaan. Ik zeg met opzet nog niet "ziel», omdat aan dat Hollandsche woord gedachten verbonden zijn, die het Tobeloreesche gikiri niet heeft. Het geeft wel "ziel » terug, in zooverre men daaronder verstaat, dat deel des menschen, 't welk bij den dood niet sterft, maar verdere functies kent men er niet aan toe. Het woord $n j a w a$, 't welk er nu parallel mee gebruikt wordt, is bekend genoeg. Het heeft in het Maleisch de beteekenis geest, leven; poetoes njawa: sterven, den geest geven.

Het is nu wel kenmerkend dat men, waar men voor "mensch * een ander woord nam, men niet als de Ternatanen nam " $m a$ noesia», maar "njawa», 't welk zeker in beteekenis meer met "gikiri» overeenkomt, dan "manoesia". Het heeft dan ook dezelfde beteekenis gekregen, èn mensch, èn geest, of geestelijk beginsel. Even goed als men kan zeggen: o gikiri manga gikiri, zegt men: o njawa manga njawa: de mensch zijn geest of ziel. Ik zeg dit hier vrijmoediger, omdat dit woord reeds een beteekenis heeft, maar men houde in het oog, dat het volkomen gelijkbeteekenend geworden is met "gikiri".

Het derde woord «o gurumini» heeft nog grooter moeilijkheden voor de vertaling. Het door het woord angeduide begrip is door Dr. A. C. Kruyt in zijn "Animisme» weergegeven met "zielestof». Zonder nu daarop eenigszins kritiek te willen uitoefenen, kan ik mij toch met dat woord niet vereenigen aangezien het $\mathrm{m}$. i. onlogisch is. De begrippen «ziel» en "stof» zijn voor mij met elkaar in wederspraak. Echter het is moeilijk wat 
beters te geven, omdat de gedachte, door het woord weer te geven, aan ons Westersch denken volkomen vreemd is.

Wat toch verstaat men er door? Niet ziel, zooals wij ons dat denken, evenmin geest. Het is een "kracht», waardoor de ziel, de persoonlijke ziel of geest, de gikiri of njawa zich kan openbaren.

Ik zal er voor gebruiken «levenskracht», echter met dien verstande dat men goed trachte na te gaan, wat ik daaromtrent hier zeggen wil. Dit woord toch geeft ook alleen bij benadering, en niet zuiver het begrip weer. Het wil toch niet zeggen levenskracht in dien zin dat waar geen gurumini is geen leven zou zijn. De ziel, de gikiri, leeft ook zonder gurumini, maar zij mist dan de kracht dat leven te toonen, zij is willoos overgegeven aan andere machten. Men zou kunnen zeggen, dat tijdens het leven, de gurumini de band vormt tusschen het lichaam en de gikiri, en dit is ook betrekkelijk zoo, daar, waar de gurumini verdwenen is, de band tusschen lichaam "roèhe en ziel, gikiri, ophoudt te bestaan, m. a. w. de dood is daar het gevolg van, maar daar staat weer tegenover, dat er sterven kan plaats hebben ook zonder scheiding tusschen gurumini en gikiri, dus de band tusschen lichaam en ziel kan ook verbroken worden, zonder dat de gurumini hierin betrokken is. Logisch is dit niet, maar ik zeide reeds dat we geen logisch systeem mogen verwachten.

Het best te omschrijven is dus de "gurumini» als "de kracht waardoor de ziel zich kan openbaren». Is hij niet meer aanwezig, dan kan de ziel of "gikiri" nog wel aan het lichaam verbonden zijn, maar dit ligt nu toch als dood neer. Het beweegt niet meer, het hoort niet meer, het spreekt niet meer. Het ademt nog wel, maar dat is geen functie die men aan de gurumini toeschrijft, maar aan het lichaam, het ro ehe.

Is de gikiri zonder gurumini in het "jenseits», dan is zij willoos overgeleverd aan andere machten, is zij met gurumini heen gegaan, dan blijft zij krachtig en kan zich doen gelden.

Het woord op zichzelf wordt in andere talen, in het Galelareesch b. v., gebruikt voor "schaduw». In het Tobeloreesch doet men dat ook, maar voegt er aan toe: ma dorou: slecht. Men kan dus niet zeggen, dat gurumini door schaduw vertaald kan worden, en dan nog bepaaldelijk alleen 'menschelijke schaduw», want voor schaduw in het algemeen gebruikt men een ander woord: o hohongo. 
Men ziet dus in de schaduw de afspiegeling der gurumini, maar noemt haar "de slechte», wellicht omdat zij haar aanwezigheid verraadt, en dus daardoor oorzaak wordt, dat de gurumini wordt aangevallen.

Want die staat aan heel wat aanvallen bloot. Men zou toch kunnen zeggen, dat de gurumini de kostbaarste is, der drie bestanddeelen, waaruit de mensch bestaat. Het leven er zonder is waardeloos, dus staat zij steeds aan aanvallen bloot dergenen die er zonder zijn, n.l. booze geesten, en deze aanvallen zijn de ziekten.

Alvorens verder te gaan, moet opgemerkt worden, dat gu ru min i, zoowel eigen is aan dieren en planten, als aan menschen. De mensch heeft het meeste, en is daardoor het voornaamste wezen, maar ook andere levende wezens hebben het. Evenzoo planten, spijzen, etc. Maar toch, hoewel dit zeker waar is, schijnt men zich de menschelijke gurumini, en die van dieren en planten, niet gelijksoortig te denken. Dat is reeds merkbaar daaraan, dat men alleen de menschelijke schaduw gurumini noemt, terwijl toch logisch die van dieren en planten, ook aldus zou moeten heeten. Maar dit is het geval niet. Wel kan men nog zien, vooral uit de medicijnen die men bij verschillende gelegenheden gebruikt, dat men een gurumini aan dieren en planten toekent, maar men drukt dit toch nooit meer uit, dan alleen bij het aanbieden van offers, waarvan men de geesten de gurumin i laat eten, welks afschaduwing de damp is, de wasem. Mogelijk is, dat vroeger het geloof aan een algemeene gurumini bestaan heeft, maar men dat langzamerhand heeft vergeten. Echter, is ook even goed mogelijk, dat men oorspronkelijk alleen de gurumini aan den mensch toegekend heeft, en de algemeene animistische opvatting van anderen overnam.

Hoe is nu de verhouding dezer drie bestanddeelen tegenover en met elkaar? Het geboren wordende kind schijnt zijn "gikiri" mede te brengen.

Waar die vandaan komt, weet men niet al te goed meer. Eigenlijk is het een vraag van ondergeschikt belang voor een volk als de Tobeloreezen. Men houdt zich heel weinig op, bij wat niet van rechtstreeks belang is. Toch is de meening dergenen, die op dit punt een meening hebben, dat de "gikiri, komt van "Gikiri moi», het Opperwezen of de hoogste gikiri, misschien de oorsprong der "gikiris». 
Het is daarom nog de vraag of oorspronkelijk wel «Gikiri moi, en «Djou ma dutu»: de eigenlijke Heer, wel een en dezelfde persoon geweest zijn. Op het oogenblik zijn ze dat wel, maar door het weinige belang, dat ze hebben voor het leven der Tobeloreezen, zou het niet te verwonderen zijn, zoo ze saamgesmolten waren.

In elk geval, het geboren wordende kind heeft een gikiri of $\mathrm{njawa}$. Op welk tijdstip van het ontwikkelend vruchtleven die "gikiri» erin komt, weet men niet. Hij is aanwezig, als het kind levend geboren wordt, dat is zeker.

Anders is het met de "gurumini». Die schijnt bepaaldelijk na de geboorte erin te komen. Men zou denken, dat het geboren wordende kind een deel van de gurumini der ouders mee moest brengen, minstens van de moeder, maar dat schijnt toch het gevoelen niet te zijn. Het kind moest dan met een volmaakte "gurumini" geboren worden.

En dat is toch zoo niet. Men zegt van een kind, dat levenloos geboren wordt, of ook van een, dat kort na de geboorte sterft: "ma gurumini i adonoài», de gurumini is er nog niet, of ook: "ma gurumini i tiaioahi»: de gurumini is nog niet klaar, niet gereed.

Echter toch, onmiddellijk na de geboorte komt hij, want men toonde mij, op mijn vraag, bij een jonggeboren kind deszelfs schaduw, om te bewijzen, dat hij aanwezig was. Natuurlijk is dit niet logisch, want een lijkje zou ook schaduw geven, als men het, zooals men het levende. kind deed, tegen het licht hield. Maar ik zeide reeds, men is niet logisch.

En vanwaar nu de gurumini? Ik geloof niet, dat iemand er een antwoord op weet te geven. Ik zou denken, dat men meent dat de gurumini van de moeder meegebracht wordt, en dat uitdrukkingen als: de gurumini is er nog niet, bij een doodgeboren kind, beteekenen: "het is niet volmaakt geboren». Maar dan zou, met elk geboren wordend kind, de gurumini der moeder moeten verminderen, en men zou dus bang moeten zijn voor het baren, en niets is toch minder waar dan dat.

De vraag naar het »vanwaar», moet dus wel onbeantwoord blijven.

Dat de gurumini groeit met het kind, en, naar het kind in grootte toeneemt, ook sterker wordt, gelooft men natuurlijk wel, want een kind wordt gemakkelijker een prooi van een 
aanval van booze geesten, dan een volwassene. Men kan denken, dat eerst door de moedermelk, en later door het voedsel, gurumini toegevoerd wordt. Dit zou volkomen logisch zijn. De gurumin i bevindt zich ook in alle deelen van het lichaam, hoewel niet overal even veel, en het is daarom natuurlijk, dat men niet gaarne zijn haar knipt b. v., aangezien men zichzelf daardoor van een deel levenskracht berooft.

Ziekte heeft vermindering van gurumini ten gevolge, dood door ziekte treedt in door uitgeput zijn der gurumini.

Ik hoop dat na deze algemeene beschouwingen, wat verder medegedeeld zal worden, door den lezer beter zal worden begrepen.

\section{HOOFDSTUK 8.}

\section{Dorpstempels : o Halu.}

O Halu. Ik meen het woord aldus gehoord te hebben, maar in vergelijking met verwante talen, zou het ook kunnen zijn... halo. Uit het woord zelf weet ik niets af te leiden omtrent de beteekenis dezer gebouwen of hun doel.

De vorm is deze: op twee rijen palen rust het middendak, en aan weerszijden is daar nog aangehecht een zijstuk, rustende op een rij lagere palen. Men heeft dus vier rijen palen, waarvan de buitenste aanzienlijk lager zijn dan de twee middenste rijen, waarop het dak rust. Wanden heeft men niet. Het is dus een open loods. De palen zijn dikwijls fraai(?) besneden met allerlei emblemen, een slang, een hagedis, een krokodil, vrouwenborsten vooral, ook wel bladeren, kortom, met allerlei snijwerk.

Sommige dezer gebouwen zijn werkelijk heel fraai.

Wanneer ik zeg dorpstempels, is dat nog maar betrekkelijk waar; aangezien de Tobeloreezen zelf er nooit meer gehad hebben dan drie, want de hoana Lina, schijnt er geen bezeten te hebben. Wel Gura, Huboto en Momulati. Later is nog die voor Hibua Lamo gebouwd, dat wil zeggen, dat dorp heet aldus naar den tempel, in het Ternataansch: sibua, loods, dus: groote loods.

Daarin heeft Lina gastvrijheid genoten, en voordien wel bij Gura, naar 't me voorkomt.

Bij de Kausche Tobeloreezen heeft het gebouw meer de beteekenis van een dorpstempel, omdat elke onderafdeeling daar 
in een eigen dorp woonde, en ook in dat dorp een "halu» maakte.

Wat is het nu eigenlijk? De woonplaats van de Wongemi, de stamgeest, of van de andere geesten der afgestorvenen?

Het komt mij voor van niet, want die denkt men zich in de meeste gevallen niet daar. Maar het is de verzamelplaats waar de afdeeling, of ook wel de stam bijeen kwam om feest te houden, om te beraadslagen, om ceremonieele handelingen te verrichten enz.

En bij die verzamelingen dacht men zich natuurlijk ook de dilikinis (zie hoofdstuk 22), en riep men de wongemi's of stamgeesten. Die kwamen dus daar met de menschen bijeen, maar men heeft zich die daar niet gedacht, als men niet officieel vergaderd was.

Ook heeft men volstrekt geen buitengewone eerbied voor het gebouw zelf. Men maakt het gezamenlijk, het moet in orde zijn, omdat men anders beschaamd is, maar nooit hoorde ik, dat men ziekte of onheil vreesde, omdat de halu niet in orde was. Men loopt er ook vrij uit en in, maar ik heb niet gezien dat men het aan vreemdelingen tot verblijfplaats of logeerplaats gaf, ook niet, dat men die er ontving, zooals dat wel bij andere volken het geval is.

Bij de Kausche Tobeloreezen is dit wel wat anders, omdat die te zamen elken avond de avondmaaltijd in de halu gebruikten, gezeten aan twee lange tafels, mannen en vrouwen elk aan een kant.

Elk brengt zijn eigen voedsel mee, maar men eet gezamenlijk en drinkt natuurlijk daar ook bij, zoodat de dag daar in de halu besloten wordt. Toch geloof ik niet, dat men ook daar er vreemdelingen in laat logeeren. Bij de Tobeloreezen zelf is echter van dat gezamenlijk eten geen sprake, uitgenomen bij algemeene feesten.

De particuliere feesten houdt elk in zijn eigen huis, en dat is bij de Kausche Tobelo's evenzoo. Die soort van gezelligheid, om 's avonds met elkaar te eten, zooals de Kausche Tobeloreezen dat doen, heerscht op Tobelo ook wel, maar men vergadert dan eenvoudig bij den een of den ander die palmwijn heeft, en eet daar te zamen, en drinkt te zamen, en zingt te zamen, en het gevolg is dan wel dat men dan ook maar op die plaats in slaap valt, juist niet tot bevordering van de goede zeden of van de volksgezondheid. 
Om dus echter van deze gebouwen te spreken als van "tempels» in den zin van "gewijde gebouwen" heeft geen zin.

Het zijn verzamelplaatsen, en heeft men er geen meer - en wij hebben te Tobelo er eigenlijk maar één echte meer gekend dan doet voor een gelegenheid een inderhaast opgericht bamboeloodsje, precies dezelfde dienst. Men komt dan daarin bij elkaar, houdt feest, roept geesten, enz.

Mogelijk is, dat ze vroeger, toen men nog meer op krijgstochten uitging, een iets grooter rol speelden, maar zeker is dat ook niet. Bij de Tobeloreezen heeft het gebouw nog een iets meer gewijd tintje, dan bij de Kausche Tobeloreezen, want bij hen is het heelemilal een plaats van gezellige bijeenkomsten geworden.

\section{HOOFDSTUK 9.}

\section{Hoogste Wezen.}

Hoewel er $n u$ in den cultus der Tobeloreezen volstrekt niets is, wat op een Hoogste Wezen duidt, niet de minste vereering daarvoor, zijn er toch wel namen voor, die aantoonen dat men het wel kent, en het begrip dus niet vreemd is.

Wat aangaat de namen, men spreekt van Djou o Gikiri moi, of kortweg, o Gikirimoi; van Djou ma dutu, en ook van $\mathrm{Djou} L \mathrm{~L}$ tala, terwijl nog een heel gewone aanduiding is: Unanga daku, Hij daarboven. Namen dus genoeg. Gikiri moi, beteekent één gikiri of de ééne gikiri, misschien de gikiri of de voornaamste gikiri. In elk geval wijst dit woord op verwantschap met den mensch, die immers ook gikiri heet (zie hoofdstuk 7) en met de ziel, die ook met dien naam benoemd wordt. Men zou daaruit kunnen meenen, dat het woord wellicht beteekent: de oorsprong der gikiris, de eene, waaruit allen voortkwamen. Onmogelijk is dat niet, maar toch zijn dit alles bespiegelingen, want het woord zelf zegt uiterst weinig. Het is ook in alle Halmahera-talen ongeveer gelijkluidend, en men treft het overal aan, bij alle stammen.

Het woord «Djou ma dutu kan beteekenen, de Heer, de eigenlijke Heer. In dien zin wordt het woord "ma dutu malen gebruikt. Het kan ook zijn: de heer de eigenaar, hoewel dan toch eigenlijk een zelfstandig naamwoord voorafgaan moest, 
waarop het «eigenaar» slaat; want zoo is het spraakgebruik: o tau ma dutu b.v.: de eigenaar van het huis. Dus is spraakkundig het meest te zeggen voor de beteekenis, de eigenlijke Heer, de echte Heer.

Of nu dat woord oorspronkelijk hetzelfde aangeduid heeft als: o Gikiri moi, is niet uit te maken. $\mathrm{Zij}$ worden nu wel voor 'tzelfde begrip gebruikt, want beiden duiden : «het Hoogste Wezen » aan. Zoo ook het woord $\mathrm{Djou} \mathrm{Latala,} \mathrm{waarvan} \mathrm{men} \mathrm{geen}$ naderen uitleg weet, dan dat het beteekent: de hoogste Heer!

Het zijn dus nu in elk geval drie namen voor hetzelfde begrip, en zoo is ook de uitdrukking " $\mathrm{Unanga} \mathrm{daku}$, Hij daarboven, elk begrijpt er steeds hetzelfde onder.

De Christelijke Zending heeft van deze vier uitdrukkingen «Djou Latala» gekozen, omdat dat woord het minst gebruikt wordt om bij te zweren. Het zal dan ook wel het jongste wezen, en de Islam niet vreemd aan zijn verbreiding, want de Mohammedanen gebruiken het natuurlijk ook.

Wat de woorden op het oogenblik nog te beduiden hebben? Niet veel, want, zoo we reeds zagen, het zijn slechts woorden, aangezien de cultus er niet mede rekent.

Echter, let men er op, hoe deze woorden gebruikt worden, dan is dat toch wel merkwaardig. Men zweert er doorloopend bij. Bij het minste geschil dat men heeft wordt de hand opgeheven en het is: Hij daarboven weet het! of: Djou madutu! Ook wêl slechts: Hij boven zal je wel krijgen hoor! Mij dunkt, dat dit er toch op wijst, dat er iets weggeraakt is in dezen.

Zoo we zullen zien in het Hoofdstuk over de Wongemi heeft men waarschijnlijk, het offer voor het valsch zweren etc. wel aan God (wij gebruiken dit woord hier als vertaling voor al deze uitdrukkingen) gebracht.

Gewoonlijk geeft men ook nog dadelijk toe, dat de mensch van God afstamt, dat de gikiri van God komt. Dat kan ook wel haast niet anders. Wat nu het Sjamanisme nog meedeelt, past niet in het stelsel der Tobeloreezen, terwijl het zichzelf bovendien nog leelijk tegenspreekt in dezen, zoo wij zien zullen in het Hoofdstuk over het Sjamanisme, maar toch vindt het wel instemming bij het volk.

Hoe het toch komt, dat men nu niets meer doet aan vereering van den Heer die toch bij alles aangeroepen wordt als getuige, zelfs wiens straffen men inroept? Ik weet het niet. Zeker is, 
dat men ook met deze straffen niet meer rekent, en zóó lichtvaardig zweert, dat men wel gevoelt, dat alle waarde aan deze eeden reeds van te voren ontzegd moet worden. Dat het straffend ambt $n u$ aan de Wongemi toegekend wordt, zullen we zien, maar mij dunkt, het is wel duidelijk dat dit niet altoos zoo geweest kan zijn.

Het meest voor de hand liggende is wel, dat bij het stelsel omtrent de dooden en geestenvereering, zooals zich dat langzamerhand ontwikkeld heeft voor God geen plaats is. De ziekmakende invloed als gevolg van handelingen tegen den adat is eigenlijk een anachronisme, want in het stelsel past dat niet. Is het leven afhankelijk van de gurumini, de levenskracht, en wordt die òf opgebruikt òf verminderd door booze geesten: tokata, dan moet men andere oorzaken voor ziekten uitschakelen. En zoo is hoogstwaarschijnlijk de ziekmakende kracht van God, als straf over gepleegde overtredingen, ook wel uitgeschakeld, en gebracht bij de overledenen, bij de Wo ngemi, die daardoor langzamerhand tot een soort God werd.

In het stelsel zooals het $n u$ is, kan God niets zijn in het leven van den mensch, en dat zal wel de oorzaak zijn, dat de Godsvereering weggeraakt is. De Heiden vereert niet uit eerbied, die is hem volkomen vreemd. De grond voor al zijn handelingen is altijd utiliteit. Hij doet alles wat nut heeft voor hem, en waar dus de vereering van God geen nut meer kan afwerpen, moest die wel vervallen.

In het animisme is een persoonlijk God tot niets nut. De macht gaat op elk gebied aan de geesten over, en wat doet men dan nog met God? Er bij zweren, en daardoor getuigenis geven van een vroeger standpunt. God als Wetgever heeft men natuurlijk ook uitgeschakeld. Wat mag of niet mag, wordt door de adat bepaald, en ook deze zet zich op een volkomen utilistisch standpunt. Wat schadelijk is voor den stam onderling, mag niet, maar waar de stam er niet door benadeeld wordt, mag het wel. Stelen onder elkaar is verboden, strafbaar zelfs, maar diefstal of roof buiten den stam mag wel. Moord onder elkaar is verboden, strafbaar, maar moord buitenaf, buiten den stam, is heel geoorloofd, enz. Bij alles staat het nut voorop, het egoïsme heerscht ten volle. Maar natuurlijk, ook dat is doodend voor elke gedachte aan Godsvereering. De geestenvereering heeft de Godsvereering volkomen gedood. Natuurlijk dat dit niet met bewust- 
heid geschied is, het is alleen het uitvloeisel van het eenmaal ingenomen standpunt.

Het sjamanisme heeft dat ook niet beter gemaakt, want dàt verplaatst God volkomen uit het leven, naar het doodenrijk. God is daar uitsluitend nog de heerscher in het doodenrijk, zoodat, wanneer men nu nog met God rekent, men dat ook uitsluitend doet met de gedachte aan dood en sterven. Het is de eenige functie die sommigen (hoewel zeer inconsequent) nog aan God toekennen, dat God doodt. Het is voor het Christendom zelfs geen geringe taak, God in een ander licht te brengen. Een Heiden riep eens uit: had ik God hier, ik zou met hem willen boksen, want hij is de oorzaak van ons aller dood.

$\mathrm{Nu}$ is het mogelijk, zelfs zeer waarschijnlijk, dat «Djou ma dutu > oorspronkelijk de Heer over levenden en dooden geweest is, maar waar de levenden zich aan Hem onttrokken hebben, blijft toch nog alleen maar het doodenrijk over, of liever, aan God is dan alleen nog maar de functie overgebleven, te dooden. Maar aangezien men Hem toch eigenlijk ook niet meer in die functie erkent, daar dat met het stelsel in strijd is, is God in werkelijkheid volkomen dood voor den Tobelorees; hoeveel namen Hij ook moge dragen, en hoeveel maal die namen ook gebruikt mogen worden. Ze zijn een volkomen ledige klank geworden. Het is waar dat men God nog erkent als oorsprong van het leven, maar daar $\mathrm{Hij}$ verder uit het leven wegvalt, beteekent dat natuurlijk ook niets meer.

Niemand doet iets om der wille van God, en niemand laat iets om der wille van God, ergo, nog eens, God is dood voor den Tobelorees.

\section{HOOFDSTUK 10.}

\section{Wongemi : stamgeest.}

Men geeft den naam Wo n ge mi aan de oudst bekende Voorvaders, of wel de oudst bekende Hoofden, der verschillende Afdeelingen.

Men denkt zich als de machtigste de Wongemi van de voornaamste hoana want deze alleen roept men aan bij de ceremoniën.

Bij de Kausche Tobeloreezen heeft men er heel wat meer dan 
bij de Tobelo's zelven, omdat men daar voor elk ondergedeelte van een hoana, er ook nog weer een heeft. Men zegt daar: als iemand bekend gestaan heeft als dapper, vele vijanden heeft verslagen, niet slecht geleefd of zoo, dan kan hij voor het vijfde geslacht al wel tot Wongemi zijn.

Bij de Tobeloreezen zelf heeft men voor de hoana Lina Tingidu, die ook als de voornaamste erkend wordt, voor de hoana Hibua-lamo en Gura, Tuada, voor de hoana Huboto Tutuhuru en voor de hoana Momulate Ijene.

Bij de Kausche Tobelo's heeft men voor de hoana Bòëng, onderafdeeling soa Hukum: Turuwele, meteen als hoofdstamgeest geldende; onderafd. so a Manjira: Brani, onderafd. soa Tungulo: Hohodono; van de onderfd. soa-Sangadji, mij onbekend; van de hoana Madong, onderafd. soaKimalaha Djobiri, van de soa Mahino Raange. Van de hoana Seleruru, onderafd. soa Kimalaha. Kalabatu, soa-Manjira Sibulis; van de hoana Tonuai: Karating. Men ziet, de Kausche Tobelo's hebben er heel wat meer dan de Tobeloreezen zelf. Waar zij zooveel namen hebben, voor elk onderafdeelinkje weer een aparten naam, is het niet onwaarschijnlijk, dat dit namen zijn van personen, die men nog gekend heeft. Maar vreemd blijft het wel, dat men er zooveel heeft. Misschien is dit zóó gegaan, dat oorspronkelijk ook elke hoana er maar één had, maar dat door de verdeeldheid later, bij twisten, men van elkaar ging, en van elkaars Wongemi niets meer weten wilde, en er dus zelf maar een zocht onder de eigen voorvaderen.

Bij de Tobeloreezen zijn het wel mythische personen, want aan Tingidu wordt zóóveel toegeschreven, dat het met den besten wil niet voor waarheid te houden is. Ook geeft men toe, dat er heel veel personen van dien naam geweest zijn.

Dat men zoowel bij de Kausche Tobelo's als bij de Tobeloreezen zelf slechts één aanroept om mee te gaan in den oorlog, en bij ceremoniën, wijst dunkt me duidelijk aan, dat men oorspronkelijk slechts één erkende. Die ééne is ook wel zoowat vergoddelijkt, want men schrijft hem alle functies toe, behalve de voortbrenging.

Echter, nu men niet meer uitgaat om te oorlogen, is wel de hoofdfunctie, het letten op den eed en op booze woorden, en ingevolge daarvan, het handhaven van den adat, vooral ten 
opzichte van onzedelijkheid. D. w. z. hij belet de onzedelijkheid niet, maar hij handhaaft de adat, dat voor elke overtreding betaald moet worden, zooals het behoort. In dat geval is er natuurlijk ook geen schuld of overtreding die gezoend worden moet.

Men heeft nu allerlei voorstellingen omtrent deze godheid.

Volgens den eenen gomatere (sjamanen priester, zie hoofdstuk 12), de eenige personen die hem ooit bezoeken, zit hij recht overeind, ergens, waar weet men niet, en ruikt steeds naar wat beneden gebeurt. Ruikt hij adat-overtreding, dan wordt hij boos, en zendt ziekte. Volgens anderen zit hij met uitgestrekte hand alle eeden vast te houden, en wordt boos indien men die niet houdt, en zendt dan ziekte of laat den eed vallen.

Ook bij de waarzegging speelt hij een rol, want men roept hem daarbij in de eerste plaats aan.

Nog schijnt men hem wel te beschouwen als de handhaver van het gezag der Hoofden, daar hij zelf het eerste Hoofd geweest is, en de nu heerschende Hoofden dụs zijn opvolgers zijn.

Waar is hij? In de "halu zegt men, maar heel goed komt dat niet uit, aangezien men, vooral bij de Tobeloreezen zelf, zonder hartzeer een « $\mathrm{Halu}$ » laat vervallen, en zelfs de hoofdafdeeling Lina er nooit een had.

Ik denk, dat hier wel veel op rekening van het Sjamanisme gesteld moet worden, want al de verhalen hieromtrent zijn van de gomateres herkomstig.

Men roept bij het "tue-tue» (zie hoofdst. 22) de Wongemi uit het bosch, zoo 't schijnt, en is dan op zijn gezelschap niet bijzonder gesteld, aangezien men op de aankondiging: o Tingidu wo boa: Tingidu komt, antwoordt met: dat hij niet kome! en als verlost juicht bij de aankondiging: o Tingidu wo hongana: Tingidu is naar het bosch! en dat zal ook wel zoowat uitkomen, want eigenlijk is van oudsher voor den Tobelorees het bosch wel de meest geliefkoosde verblijfplaats, dus, waar zou de geest wel liever zijn dan daar? En hij zal naar de "halu» wel alleen dan komen, als hij erheen geroepen wordt, naar het me dunkt. Ook de Kausche Tobeloreezen schijnen hem zich in het bosch, zelfs in een boom geincarneerd te denken.

$\mathrm{Nu}$ is het wel merkwaardig, dat aan zoo'n hoogsten geest nooit eenige eigenlijke vereering gebracht wordt. Bij het «tuet u e wordt hij aangeroepen, maar toch maar alleen als de oudste 
of eerste der dilikinis, en voor de rest in niets van hen onderscheiden, bij de Kausche Tobelos is hij zelfs de generaalvertegenwoordiger van de dilikin is zou men zeggen, want die roept men niet meer op, maar beschouwt alleen hem, de Wongemi, als degene die mee moet gaan en helpen in den oorlog.

Is iemand ziek wegens adats- of eedsovertreding, dan wordt er een offer aan den Wongemi gebracht, maar ook het gebed dat daarbij wordt uitgesproken, ziet er wel wat verdacht uit, vooral door de toevoeging: de hemel is te hoog, kom dus naar beneden. ( $Z$ ie hoofdstuk 22). Maar een Wongemi in den hemel? Dat is nu heelemaal niet denkbaar, als zijnde hij toch ook een afgestorvene. Bij de Kausche Tobelo's heet het feest van het terugkeeren der krijgers uit den oorlog, een dankfeest aan den Wongemi, maar het ziet daar niet naar uit, en beteekent waarschijnlijk volstrekt dat niet. Het komt mij dus voor, dat wij hier te doen hebben met een overgangsproces, waarbij langzamerhand de functies, oorspronkelijk toegekend aan het Hoogste Wezen, toegekend worden aan een afgestorvene, zij het dan ook aan een beroemde. Naar het mij voorkomt is de functie van den Wongemi oorspronkelijk dezelfde geweest als die van de dilikinis, n.l. een beschermende geest, en als de eerste dergenen, die men aldus vereerde, ook het hoofd der geesten, maar langzamerhand heeft men steeds meer functies aan hem toegekend, en het Sjamanisme heeft daar wel het zijne toegedaan, zoodat de Wongemi het Hoogste W'ezen volkomen uit den cultus verdrongen heeft. Want dat is zeker, voor het Hoogste Wezen is nergens eenige plaats op het oogenblik, en men bemoeit zich volstrekt niet met Hem. Dat is toch onnatuurlijk naar het me voorkomt, te meer daar uit de volksuitdrukkingen blijkt, dat men nog eigenlijk het Opperwezen zich denkt, als toezicht houdende op de woorden der menschen, vooral ook als wreker van valschelijk gesproken eeden, of van slechte daden.

Een eedsformule b.v.b. om elkaar na het plegen van overspel stilzwijgen op te leggen, zegt niets van den Wongemi, maar luidt: Uha no hingahu done ma Djou ai gole buhanga tumidi ani tomarino wo dauru; d. i. geeft het niet te kennen, opdat niet de Heer zijn kapmes van zeven span lengte, door je hals hale. De hier genoemde $\mathrm{Djou}$ is niet de Wongemi, want die duidt men nooit kortweg zoo aan, maar men 
bedoelt daarmede het Hoogste Wezen. Ook ir de gewone eedsformule wordt de Wongemi niet genoemd. Het adathoofd houdt dan twee gekruiste zwaarden (o gole) boven het hoofd van den zweerder. In een kom is water, waarin wat afschrapsel van deze gole's, waarlangs men citroensap laat loopen. Dit moet de man drinken, terwijl het Hoofd zegt: Nako i goungu no howonua, done o gole ma gihoro de o hahika ani rorano, de ani panawa, ma nako i goungu no howono, o gahioko no kaoko, ani hidoku o gohomanga de o gorangoto, o aewani i l'ago-agomo, honganiha na kaiha o gota de ododiha ani hidoku, nako i goungu no howonua, ka ngona ani òa de ani laha, d.i.: indien ge werkelijk niet hebt overtreden, dan zij het afschrapsel van het zwaard en het zweerwater u slechts tot balsem en medicijn, maar indien ge werkelijk overtreden hebt, indien ge zeewaarts gaat zij uw deel de krokodil en de haai en groote beesten, indien ge landwaarts het bosch ingaat, zij uw deel het (vallende) hout en slangen; indien ge werkelijk niet hebt overtreden, zij het u slechts tot goed en heil.

Ook deze formule spreekt niet van den Wongemi, noch van zijn wraak maar levert den zweerder over aan de natuurkrachten, die toch door het hoogste Wezen bestuurd worden. Men begrijpt ook niet wat de Wongemi hiermede te doen heeft.

Dat de Wongemi, even goed als alle afgestorvenen, boos is over het schenden van den adat, is natuurlijk; dat hij daarvoor zijn hulp en bescherming onttrekt, spreekt ook vanzelf, dat is alle afgestorvenen wel aldus eigen, maar dat hij, naar de voorstelling een godheid zou zijn, neen dat komt me al te onwaarschijnlijk voor, en ik geloof, dat we hier eenvoudig moeten denken aan een verwordingsproces.

Het offer voor hẹt o maihi ha doaka (zie hoofdstuk 20) zal oorspronkelijk wel gebracht zijn aan den Heer het Opperwezen, daar ziet het er in zijn samenstelling ook naar uit, en daarmede valt elke aparte vereering van den Wongemi weg, en hij is eenvoudig het hoofd der dilikinis (beschermende geesten) en niet meer. 


\section{HOOFDSTUK 11.}

\section{Het geloof aan "booze geesten".}

Als booze geesten denkt men zich hoofdzakelijk «tokatas»: afgestorvenen, waarover wij handelen in Hoofdstuk 22, maar het is wel natuurlijk dat men zich nevens die nog anderen denkt, waarover wij in dit Hoofdstuk willen spreken.

$\mathrm{Nu}$ moet hier aanstonds vermeld worden, dat, met uitzonderingen, de Tobelorees op dit punt niet lijdt aan overgevoeligheid. In de totoades (vertellingen) (zie mijn "verhalen en vertellingen, Bijdr. tot de taal-, land- en volkenkunde v. N.-I. 1908), komen allerlei verhalen voor van booze toovenaars: o meki», die menschen eten, maar in de werkelijkheid, in het dagelijksch leven, houdt men daar geen rekening mee. Het is immers maar een totoade, zegt men dan.

Maar toch, natuurlijk, geestenvrees is er wel.

Sommige menschen zien geesten, in het bosch, of waar dan ook, en dat heeft een goede beteekenis als de geesten wit, en een slechte als ze zwart zijn, n.l. voor het leven van den persoon, die met het gezicht begiftigd wordt. Wat dat nu voor geesten zijn, weet men niet te zeggen. Sommigen beweren: o honehonenge: dooden, maar anderen verwerpen dat. De meest booze "booze geest" is wel de meki (zie Hoofdst. 23 fetishen.) die door den een of ander worden afgestuurd, om iemand te vernietigen. Maar heel veel schijnt deze niet voor te komen.

Dan heeft men de gomanga ma dorou: booze afgestorvene, die het ook heel lastig maakt, daar hij alle geluk weert, en als een booze volggeest optreedt. Dan heeft men nog soorten die men ook "tokata»: booze geest, noemt, waarvan sommigen uit het bosch komen, "o tokata o honganino", en weer anderen uit den grond "o tokata o tonakino». Deze richten ook kwaad aan op allerlei manier. Men schijnt ze met de gewone tokatas op een rij te stellen. "O tokata honganino» verwekt speciaal booze droomen, en maakt heel slecht gehumeurd. Door hun bezoek staat men met het verkeerde been op, zoo men zegt. Mer wapent zich daartegen door te gaan slapen met het hoofd landwaarts, tegen den wand van het huis aan $k$ ho ma iduiha» - gaan liggen met het hoofd landwaarts, de gewone uitdrukking voor "slapen gaan» - want de geest kan dan niet door den wand dringen, om bij het hoofd te komen. 
Slaapt men met de beenen landwaarts, dan dringt hij gemakkelijk binnen, want, zeggen weer anderen, als hij de voeten voelt, is dat vleesch, en daar gaat hij doorheen, maar ligt het hoofd landwaarts, dan meent hij zich vergist te hebben.

Dan heeft men o giki loa. Ik weet niet wat dat woord beteekent, of het moest zijn een giki: levend wezen, dat rechtuit loopt. Misschien is het dat, want men verstaat er onder een menschelijke weerwolf, die men soms op zijn weg tegen komt, met een vreeslijk lang uit den mond hangenden tong, en vurige oogen. Of hij menschen- of dierengedaante heeft, is niet zeker uitgemaakt, want de opgaven daaromtrent verschillen. Echter, omtrent de lange tong, en de vurige oogen, is men het wel eens. Als men maar dadelijk op zij gaat, is de ontmoeting niet gevaarlijk, maar anders wordt men een prooi van dit booze schepsel.

Dat men, zooals wel elders, bepaalde personen aanwees als weerwolven en daarom trachtte te dooden, heb ik nooit gehoord. Dan heeft men o ibelihi. Men verstaat daaronder een soort geesten die hier en daar in het bosch wonen, vooral in dicht struikgewas, aan den voet van hooge boomen. Ze zijn over het geheel nogal onschadelijk, alleen maar, men moet niet hun woonplaats omhakken of in brand steken, want dan worden zij boos en wreken zich. Wil men dus hier of daar een hooge boom, of dicht struikgewas omhakken, dan is het wel verstandig eerst iemand te halen, die van zooiets verstand heeft om latere onheilen te voorkomen.

Ook spreekt men nog wel, vooral in het Kausche over "o Setan, maar men schijnt daarmede wel niet anders te bedoelen dan wat anderen noemen "o tokata". Ook hoort men wel wanneer men b. v. met de een of ander die voor verlicht wil doorgaan, spreekt over het geestengeloof in het algemeen: och mijnheer het zijn allemaal niets dan "o Setan". Men zal dit woord wel overgenomen hebben van de Mohamedanen, zonder dat onder dien naam nu juist een nieuwe categorie van geesten haar intrek hield. Ook gelooft men aan "o naga», draken. Hoe die er uitzien, weet men niet, maar sommige stukken land meent men daardoor bewoond, en gaat men daar wonen, dan heeft dat groote kindersterfte ten gevolge.

Achter ons huis was zoo'n stuk grond. Het had een beetje wilde vegetatie, maar anders was er niets aan te zien. Daar hebben een aantal gezinnen een kleine kampong gebouwd, en 
jaren lang heel gelukkig gewoond. Toen echter in een dier gezinnen, door heel natuurlijke oorzaken, een paar kinderen stierven, vertrok de een na den ander. De naga was er toch nog, al had men gemeend dat hij weg was. Waaraan dat geloof zijn oorsprong te danken heeft, weet ik niet. Ook weet ik niet, of deze naga's identisch zijn met de naga's die bij zons- of maansverduistering geacht worden pogingen te doen die hemellichamen te verslinden, en die dus daarom met het maken van veel geraas verdreven moeten worden. Maar het is op zichzelf niet onmogelijk dat men 't laatste bijgeloof van andere volken overgenomen heeft, en dat daaruit de kinderenverslindende draak op aarde, langzamerhand ontstaan is.

Verder heeft men o Moròka, aardmannetjes, kaboutertjes. Men verstaat hieronder de vroegere bewoners van het eiland Morotai, die, zooals men zegt, verdwenen zijn, en onder den grond voortleven. Zij zijn overal, maar hebben toch op min of meer vaste plaatsen hunne woonsteden, waar zij allerlei uithalen, met groote steenen rollen, boomen verplaatsen, en wat dies meer zij.

Bepaald bang is men er niet voor. Men grond dit kaboutergeloof hierop dat er geen oorspronkelijke bewoners van het eiland Morotai meer zijn. Het eiland wordt nu bewoond door Galelareezen en Tobeloreezen gezamentlijk.

Het zou mij echter niets verwonderen indien achter dit, algemeen verspreid geloof, de een of andere historische waarheid zat. De zaak kan niet alleen het eiland Morotai betreffen, want men heeft immers het geloof ook aan den vasten wal, en wijst b. v. tusschen de dorpen Ruku en Medee een o moròka manga berera: aardmannetjesdorp aan. Daar nu is het rijk van Moro niet geweest, wel het rijk van Tolo. Nu zegt men ook wel, dat de menschen van Tolo na hun ondergang door de Ternataansche overwinning over hen in de $16^{\mathrm{e}}$ eeuw, mor ò $\mathrm{ka}$ geworden zijn. Het komt mij niet onwaarschijnlijk voor dat bij een inval de oorspronkelijke bewoners zich teruggetrokken hebben, en misschien nog lang van uit hun schuilplaatsen in de bosschen, de indringers het leven lastig maakten. Het is volstrekt niet gezegd, dat de lieden die $n u$ de kust bewonen, die indringers waren, het kan best nog veel verder teruggaan, maar ik geloof wel dat dergelijke verhalen altijd den eenen of anderen historischen achtergrond hebben. 
En natuurlijk gelooft men aan den kraamvrouwengeest, hier o putiana geheeten. Men benoemt de een of andere vogelsoort met dezen naam, hoewel niet overal dezelfde soort. Gewoonlijk de sperwer "o kawihi». Hoort men de schreeuw van dien vogel, in de buurt van een huis waar een zwangere of barende vrouw is, of wel een die pas gebaard heeft, dan moet men een net voor de deur hangen, opdat de putiana daar met zijn lange nagels in verward zal raken. Verder moet men dan ook dadelijk door een go mater e medicijn laten maken, tot afwering. Sterft echter de vrouw in het kraambed, of kort na de bevalling, of ook tijdens zij zwanger is, dan is dit een bewijs, dat de putiana zijn boos werk toch gedaan heeft. Men moet nu het kind, zoo het reeds geboren is, steeds een zakje met Spaansche peper en uien om den hals laten dragen, want dat zijn scherpe middelen, waarvoor de putiana bang is.

Ook de man moet zich nu dadelijk laten medicineeren, want hij is in gevaar, niet door de putiana die zijn vrouw doodde, maar door de gedoode vrouw zelf, want die wordt nu ook een putiana. Haar doel is voornamentlijk, de schaamdeelen van den man met de lange nagels te beschadigen, en daarom moet hij zich, vooral des avonds zeer in acht nemen bij het ontblooten. Wat betreft het lijk van de gestorven vrouw, men moet in elke hand een ei leggen, opdat zij haar handen niet dicht zou kunnen knijpen om te grijpen, dan braken immers de eieren! en men steekt citrus-dorens onder de nagels, opdat die niet lang kunnen worden, en nog moet men een mengsel van suikerstroop, vermengt met cocosolie in de oogen gieten, opdat zij haar prooi niet zien kan. Sommigen leggen nu nog een dik net over de kist, anderen nagelen het omhulsel van het lijk aan de kist vast, alles middelen om te beletten, dat de booze geest uit de kist komt en den man of het kind aanvalt.

In het Hoofdstuk over het Sjamanisme zal men lezen dat een gomatere een specialiteit voor deze gevallen geworden was, aangezien hij zoodra men den putiana in de buurt vermoedde, dien beteugelde, door hem tot zijn $\mathrm{djini}$ te maken. 


\section{HOOFDSTUK 12.}

\section{Het Sjamanisme.}

Bij het sjamanisme zeggen de mediums bezeten te zijn door éen bepaalden geest, den $\mathrm{djini}$, door wiens tusschenkomst het verkeer met de andere geesten plaats heeft.

Het woord $d j i n i, d j i n$, wijst natuurlijk van zelf reeds op zijn vreemden (Mohammedaanschen) oorsprong.

De mediums, of sjamanen, noemt men o gomàtere, waarschijnlijk van gementar, Mal.: beven, sidderen, trillen. Tegen deze verklaring is, dat het Galelareesch g o m a h a te heeft, dat eigenlijk met den besten wil niet van getar-gementar is af te leiden. Mogelijk is, dat men daar het Mal. woord niet begreep, en het dus een meer Galelareesche klank gaf. Het duidt ook op den vreemden herkomst van dezen cultus. De go matere kan evengoed een vrouw als een man zijn, ja het schijnt zelfs wel, dat vrouwen nog de meeste geschiktheid hebben voor dezen dienst, wat, met het oog op de zenuwen nu juist niet te verwonderen valt. Hoe men ertoe komt gomatere te worden?

Gewoonlijk is dit het gevolg van door een gomatere gemedicineerd te zijn, want, wanneer ook na herhaalde genezingen toch telkens de ziekte terugkeert, zegt de gomatere wel, dat de persoon in kwestie door zijn djini gezocht wordt voor zijn dienst. Zoo iemand wordt dan o muri: leerling, woont de ceremoniën bij, en kan zich straks ook zelf laten begeesten. Anderen worden door het een of ander getroffen, 't geen dan, volgens verklaring van den gomatere, door een djini gezonden wordt, die hem roept. Weer anderen vinden het een of ander voorwerp, 't geen een wonderlijke indruk op hen maakt, zij zoeken er wat achter, worden er zenuwachtig over; als het maar niet iets beteekent, en straks verklaart de gomatere wien men erover raadpleegt, dat het gezonden is door een $\mathrm{djini}$, die gediend wil worden. Hieruit blijkt al, dat men dikwerf een vermenging heeft van sjamanisme en fetichisme, zoodat men tusschenbeide niet weet, van welk dezer beide men spreken moet.

Wil de "muri» zich tot guru: meester in de Djinidienst doen maken, dus gomatere worden, dan zijn de ceremoniën om daartoe te komen bij alle gomateres niet gelijk. Elk houdt er zoowat een eeredienst op eigen handje op na. Hoofdzaak is wel dat de a.s. gomatere eenigen tijd in afzondering doorbrengt 
op de plaats, waar zijn meester gewoon is voor zijn djini te dansen, te pitoko zoo men dat noemt.

Men spreekt er zelden over, dat personen een $\mathrm{dj}$ in $\mathrm{i}$ hebben, maar wil men aanduiden dat iemand zich als moerid of goeroe met dezen dienst inlaat, dan zegt men kortweg: wo: hij, of mo: zij, pitoko, zij danst den djinidans. Dit woord aho pitoko» beteekent: trappelen, stampen, als ongeduldig zijnde, en wellicht dat men daarom, naar de haastige klop van den Djinitrom, het dansen aldus noemde.

In het Galelareesch en Ternataansch noemt men dezen dans "salai», en heel enkel hoort men te Tobelo: ‘jo halai», maar gewoonlijk zegt men: jo pitoko.

Is nu de leerling door de afzondering en ook vooral door vasten en allerlei geheimzinnigheden rijp, voor het in zich doen komen van den geest, dan verzamelen zich al de leerlingen bij den meester op de dansplaats. Gewoonlijk neemt die het heele middenstuk van het huis in. Het is een paar voet van den grond en heet: ma pola. Tegen den voorwand van het huis is, aan den bovenkant, een soort vlondertje opgehangen: o hakoro, waarop gewoonlijk een bord, waarin de fetis, waaraan de $\mathrm{Dj}$ in $\mathrm{i}$ verbonden is. Tijdens het dansen bevinden zich daarom heen bladeren van den arenpalm, als versiering: "o bileres. In den wand boven de hakoro, is een opening, waarlangs een arenpalmblad naar buiten gestoken is, dat onder tegen het dak van de voorgaanderij gebonden, aan den benedenkant verbonden is, met een voor het huis geplaatsten staak, die met allerlei bladen en takken omwonden en versierd is. Die bladen en takken hebben allen de een of andere zinnebeeldige beteekenis, soms aan hun naam ontleend, soms aan hun geneeskrachtige beteekenis of werking. Deze opgesierde staak is de eo djini ma gota , de boom van den Djin, en dat arenpalmblad, dat onder langs het dak gebonden, de verbinding tusschen den staak, en de fetis, op de hakoro boven in het huis tot stand brengt, is de o djinimangekomo, de weg voor den djini. Is nu de $\mathrm{djini}$ van over zee komende, dan is het huis met het front naar zee gebouwd, in het andere geval, als de geest uit het bosch moet komen, is dat front naar den landkant gekeerd.

Soms ziet men ook wel, van de staak aan den zeekant van het huis, naar de zee, naar een tweede staak die daar geplant is, nog een soort snoer van palmbladeren gebonden, om die 
gemeenschap te onderhouden. Ook ziet men, dat na afloop van den Djini-dans, de staak vóór het huis wordt weggenomen en verplaatst naar het strand.

Op dezen dansvloer dan is het gezelschap vergaderd, de a. s. gomatere ligt op den vlonder, gewoonlijk dichtgedekt met een sarong.

De temperatuur is natuurlijk nog al hoog, en niet heel frisch.

Gewoonlijk heeft men nog schotels met vuur, waarop wierook gebrand wordt, en nog heeft men jonge pinang-palmbloemen die ook een sterk bedwelmende geur verspreiden. Er is een orkest aanwezig, 't geen de noodige trommels en gongs zal bewerken, en soms ook nog een of meer inlandsche violen. De muziek begint, de trommels en bekkens worden in een eigenaardig zenuwachtig tempo geslagen. Het klinkt zeer opwindend.

Tegelijkertijd beginnen de leerlingen te dansen, terwijl de gomatere zijn aandacht wijdt aan den aanstaanden meester. Dit dansen, liever huppelen of springen, is ook bij allen wel verschillend, zooals ook de $\mathrm{djin}$ is verschillend zijn. Tijdens de muziek en het dansen begint de gumatere den candidaat te schudden en te stooten, heen en weer te rukken, kortom, alles te doen om de zenuwachtige stemming waarin de candidaat verkeert, nog te verhoogen. Het doel is, dat hij zal gaan rillen, beven, schudden, een soort zenuwstuip krijgen, als het heel mooi is, bewusteloos worden. Zoodra de candidaat min of meer begint te rillen, versnelt de muziek zich tot een razend tempo (ma djini wo hahara, de djini begint te beven, zegt men) want nu komt het er op aan.

De menschen doen met hun mond een eigenaardig snorrend geluid hooren, bij elkaar is het het dolste, zenuwachtigste tooneel, wat men maar kan bijwonen. Verder roepen de muzikanten onafgebroken: in o, in o, harenino: kom, kom, vaar in hem! Men zegt, dat een geruisch gehoord wordt langs de palmbladeren, en dan komt de djini in den candidaat, en hij wordt bewusteloos, begint soms te stuiptrekken, kortom, het is gelukt, het tempo der muziek verlangzaamt zich, en het gaat nu kalm aan. Eigenlijk moet de candidaat nu opstaan en meedansen, maar gewoonlijk is hij daartoe te uitgeput. In elk geval, hij is een go m a t ere geworden.

Echter het gaat niet altijd gemakkelijk. Sommige menschen 
nebben nu eenmaal sterke zenuwen. Het duurt soms dagen lang. Dan moet onderzocht worden, waaraan dat ligt, en de gomatere vindt uit, dat de candidaat het een of andere gebod overtreden heeft, of wel het een of ander kleedingstuk aan heeft waar de $\mathrm{Dj}$ ini vies van is, of iets dergelijks. Dat moet dan natuurlijk eerst in orde gebracht worden, voor men op nieuw begint. Eens was ik er bij, dat een moeder, gomatere, een geest wilde doen varen in haar kind, een meisje van een jaar of acht wellicht. Het kind scheen echter niet heel gevoelig en op een gegeven oogenblik, toen men meende dat het lichaam al wat stijf begon te worden, en dat de muziek het "hahara»tempo had aangenomen, onderzocht de moeder eens goed, ziet het nu volkomen rustige ademhalen en roept uit op een half wanhopige toon: zij is in slaap gevallen! En zoo was het ook; niettegenstaande het helsche spektakel was het kind door uitputting wellicht, rustig in slaap gevallen. Met sommige personen lukt het in het geheel niet, die zijn bepaald onvatbaar. Menschen met krachtige zenuwen natuurlijk!

Is het echter gelukt, en de candidaat go mater e geworden, dan ontbreekt er nog één bewerking, n.l. hem of haar clairvoyant te maken. Daartoe drupt de go matere het sap van een citrusvrucht, met nog allerlei andere scherpe vochten, in de oogen van den candidaat, snijdt ook soms over de oogleden met een grashalm, en nu heeft de candidaat ook het tweede gezicht, zoodat hij ziet wat een ander niet ziet. Om dit doel te bereiken braden anderen ook wel een kippenei, 'waarover allerlei gepreveld is, en eten dat op, en ook nog andere middelen worden tot dat doel aangewend.

De gomatere is nu klaar! Hij richt zich in zijn huis ook een dansvloer in met een "hakoro», en geeft nu, als de beste waarzegster: raad en uitkomst in alle zaken. Straks neemt hij ook weer leerlingen aan, hij behandelt zieken, roept dooden op, kortom, doet alles wat des gomateres is, en dat is nogal heel veel.

We vergaten wellicht te zeggen, dat de gomatere nogal een aanzienlijke geldelijke belonning bedingt, om een ander ook tot gomatere te maken. Het is nogal kostbaar, want ieder die medewerkt, ook de muzikanten, moeten beloond worden, al is het maar met spijs en drank, en ook de meester moet goed worden beloond. Echter, men heeft het er wel voor over, want het baantje brengt, als men in trek is, heel wat op. 
Voor sommige dingen, b.v.b. het dooden oproepen bij het hahoko (zie hoofdstuk 22) heeft de adat vastgesteld het dodinguku (geschenk), bestaande uit: o kokoa moi (een mooie mat), o hiha i tuli-tulihi moi (een beschilderde schaamgordel van boombast), o tamo moi (een groote rijstkoek), o dodo o bobilanga moi (een schotel rijst gekookt met suikerstroop), o udo-udomo moi de o hude moi (een kom en een bord). Natuurlijk komt ook hierin wijziging, maar voor heel veel zaken is niets vastgesteld, en marchandeert men eenvoudig met den gomatere, voor deze aan het werk gaat.

Ook vervaardigt elke gomatere amuletten, tegen alles wat men maar wenscht, natuurlijk tegen betaling: bakau. Van een zekere gomatere werd mij bekend, dat hij aangeboden had voor een man, beschuldigd van moord op zijn vrouw, een amulet te maken, dat hem vrijspraak moest bezorgen, voor f 50.- . Daar echter de man nog hoop had, ook zonder amulet vrij te komen, bedankte hij.

Ook de waarzegging brengt heel wat op.

Sommigen zijn berucht als giftmengers, en maken daaruit een fortuintje. Er was eens een partij, die een hekel had aan het districtshoofd, en hem liever door een ander vervangen zag. Een vrouwelijk gomatere liet zich zwaar betalen, om een medicijn te maken, waardoor dat gelukken zou. Gelukt het een of ander niet, dan is men nonit verlegen, want alles heeft zijn verbodsbepalingen: mabohono, en gelukt de eene of andere kuur niet, dan heeft men vast en zeker de bohono niet goed gehouden. Op deze wijze komt men er altijd uit.

Het volk maakt nog wel verschil, bepaaldelijk tusschen gomateres die i ma luhungu, en die dat niet doen, d.w. $z$. die heelemaal zich doen verzinken, m. a. w. die bewusteloos worden, of die zich maar zoo houden. De eerste soort vindt men de beste.

De gomatere heeft nu verder van tijd tot tijd de gemeenschap met zijn djini te onderhouden, of te versterken, door een bepaald feest te geven en dan eenige nachten achter elkaar voor zijn djini te pitoko.

Gewoonlijk maken daar dan ook een aantal zieken, met moeilijk te genezen kwalen gebruik van, om ook op den vlonder te zitten gedurende dien tijd, of er bij, en aldus de genezende kracht van den djini te ervaren. Ook zet men wel flesschen met water of quasi geneesmiddelen daar neer, die door het dansen genees- 
krachtig worden, en bij verkoop, helpen de kosten van het feest te bestrijden.

Het is natuurlijk, dat men niet alleen danst, pitoko, maar zich ook door dien dans bedwelmt, zoodat herhaaldelijk de djini kan harenino, invaren, en daardoor de gemeenschap tusschen den gomatere en zijn djini meer vergemakkelijkt wordt, zoodat hij straks ook zonder te pitoko, den geest in zich kan laten komen, om dien te consulteeren. Dat is dan het gewone idu-idu, feitelijk "slapen». De gomatere legt zich neer, bedekt zich met een doek, en begint nu met de handen te kloppen naast zich op de bank, zoowat op dezelfde maat als hij gewoon is te doen kloppen voor zijn $\mathrm{dji} n \mathrm{i}$. Langzamerhand komt het lichaam in een soort bewegingen, die er zeer hysterisch uitzien, en dat alles tot straks de gewenschte flauwte of bewusteloosheid intreedt, waarna dan de $\mathrm{djini}$ weer ingevaren is (zoo 't heet) en men allerlei vragen kan stellen, het geval betreffende waarvoor de gomatere zich in slaap gebracht heeft. Men ziet het lichaam nu ontzettende convulsieve bewegingen maken, zooals men dat ook ziet bij patienten met dusgenaamde "hysterische toevallen . Het lichaam schokt hevig, rijst als een plank overeind zonder de knieën te buigen en dergelijke. Na afloop weer eerst het kloppen, daarna stilte, en de eigen geest keert weer, m. a. w. de bewusteloosheid houdt op. Ik heb gezien, dat dan de gewrichten zoo verstijfd waren, dat eenige personen noodig waren om de knieën of ellebogen te buigen. Pas als men die gewrichten weer lenig gemaakt had, door ze eenige malen met kracht heen en weder te buigen, stond de gomatere op, blijkbaar volkomen onbewust van wat er met zijn lichaam voorgevallen was. De gewone verschijnselen dus van een zwaar hysterisch toeval, waarmede het geheele doen het meest van alles overeenkomst heeft.

Oude gomateres worden dikwerf ook volkomen zenuwpatienten, en worden door niemand meer goed toerekenbaar geacht.

Maken ze zich bijzonder druk met idu-idu dan overvalt deze toestand hen ook wel, zonder dat ze zich op de gewone manier daarin brengen. Ook heb ik meermalen gezien, dat menschen, die zich vroeger hieraan overgegeven hadden, en later, door Christen te worden, zich hiervan afkeerden, en het beslist niet meer wilden, toch nog wel door dezen toestand 
overvallen werden, vooral vrouwen op den huwbaren leeftijd, die geen man hadden. Eerst was men daarover heel verontrust, en wilde dat dergelijke menschen gestraft zouden worden. Maar toen ik betuigde, dat deze menschen niet boos of slecht, slechts ziek waren, en dat een koude begieting heel veel goed zou doen ('tgeen ook werkelijk waar was), was men hieromtrent gerust gesteld.

Een vrouw deelde mij mede, dat haar vader spontaan geroepen was tot het gomatere-schap, d. w. z. dat hiertoe niet de tusschenkomst van andere gomateres noodig geweest was. Hij had stemmen gehoord, die hem riepen, hij had zijn gestorven vader en moeder gezien, en dus daaruit begrepen, dat hij tot het gomatere-schap geroepen werd. Hij wilde echter beslist niet, daar hij meende dat dit alles slechts listen van booze geesten waren, en om die af te schrikken, besmeerde hij zich met menschelijke uitwerpselen, opdat de geesten vies van hem zouden zijn, en van hem aflaten, en toen dit nog niet hielp, omwond hij zich met varkens darmen, maar ook vruchteloos. De gezichten en stemmen bleven aanhouden, zoodat hij eindelijk begreep, dat het een djini was, die zich aan hem openbaarde, en dus gaf hij nu maar toe. Hij werd gomatere, maar behoefde nooit te pitoko, het kwam vanzelf wel over hem. Hij medicineerde de menschen dan ook niet op de gewone wijze met wortels of bladeren maar hij ontving zijn medicijn rechtstreeks van den Djou (Heer), die een upahi (bode) zond om hem de medicijn te brengen!

Hier zien we dus nog al een duidelijk geval. Een man die aan zware droomen en hallucinaties lijdt, kennelijk al zenuwpatient is. $\mathrm{Nu}$ meent men natuurlijk bij alles inwerking van geesten te bespeuren. Schokt het lichaam in den slaap, zoodat men wakker schrikt, geesten hebben het gedaan. Droomt men bijzonder helder, geesten doen het, die zich openbaren. Men is zoodanig met de gedachte aan de geestenwereld vertrouwd geraakt, dat men dier werking in alles meent te zien en te voelen. En de wonderlijkste dingen worden als werking van de geestenwereld dan beschouwt. Ik herinner me, dat een zekere gomatere als grootste kunststuk vertoonde, in extatischen toestand zijn endeldarm uit te drukken, zoodat die uit het lichaam hing. $\mathrm{Ja}$, dat was nu toch zoo bijzonder en geloofwaardig, dat die man steeds grooten toeloop had. 
Weer een ander had een boek. Hoe hij daaraan kwam, weet ik niet, ook heb ik het nooit te zien gekregen, niettegenstaande ik dit herhaaldelijk verzocht. De man beweerde, dat het uit den hemel gevallen was, en dat hij nu daaruit alle aardsche en hemelsche geheimen kon lezen, vooral ook de noodige medicijnen voor zijn patienten. Nu kon de man niet lezen, en was bovendien, zoolang ik hem gekend heb, minstens kindsch, soms krankzinnig. Ook had zijn roem veel geleden, doordien de jeugd op de scholen echt leerde lezen, maar hij was vroeger door allen, en werd nog door de Heidenen, als een zeer gewichtig persoon beschouwd.

Een bekeerde gomatere gaf mij zijn fetis, een verbazend sterke, over zee gekomen, in een flesch aangedreven, lang vereerd, zeer krachtig. 't Bleek een flesch te zijn waarin een papier. 't Papier was een briefje van een wetenschappelijke maatschappij, ik geloof in Engeland, tot bestudeering van de zeestroomingen. Men werpt die op zekere plaatsen in zee na er op aangeteekend te hebben de plaats waar, en de datum waarop men die in zee gooit, opdat degene die ze vindt, ook weer zal aanteekenen de plaats waar en de datum waarop hij het vindt, om op die manier de zeestroomingen na te gaan.

En zoo heeft men allerlei. Ik herinner me, dat er eens een groot feest gevierd werd, omdat een meisje een $d j i n i$ van over zee gekregen had. Op mijn vraag, hoe ze dat wist, klonk het antwoord, dat ze 's morgens bij het naar 't strand gaan (dit is de groote W.C.) een klappervrucht gevonden had, met een spruit, half wit, half groen, die aan was komen drijven. Als dat nu niet een djini was, die door dat meisje vereerd en gediend moest worden, wat zou er dan een zijn!

Ik merkte boven op, dat de man, die zich niet wilde laten "begeesten ?, zich omwond met varkensdarmen. Dat is een eigenaardigheid van de heele djini-dienst, de afkeer van het varken. Geen gomatere die varkensvleesch eet, en 't eerste wat verboden wordt, aan hen die zich laten medicineeren, is varkensvleesch. Dat wijst er op, dat de heele zaak van Mohammedaanschen oorsprong is, want de Tobelorees is anders volstrekt niet afkeerig van varkensvleesch. Het woord waarmede in het algemeen "vleeschspijs» aangeduid wordt "o hiode" is zelfs van het grondwoord o de, varken gevormd. Wel een bewijs dat een dienst die varkens. vleesch verbiedt, niet aan het volk oorspronkelijk eigen was. Wij zullen dat nog wel verder zien. 
Wat zijn nu eigenlijk de djini? Zooals bekend is heeft het woord djin in het Arabisch wel beteekenis, maar wat verstaat de Tobelorees er onder? Dat weet men eigenlijk zelf ook niet heel goed, en het is uit al de verhalen ook niet duidelijk, 't geen wel alleen daardoor verklaard wordt, dat het systeem als zoodanig niet Tobeloreesch is, en men er dus ook niet al te goed raad mee weet.

Men wordt te dien opzichte ook al niet wijzer, als men zijn licht tracht op te steken bij Mohammedaansche Tobeloreezen, want die weten het evenmin, ofschoon ze bijna allen gomateres zijn.

Sommigen beweren dat ze "o gomanga ma dorou " booze geest geworden afgestorvenen, temmen en tot $\mathrm{Djini}$ maken. Een man dien ik kende wist de kraamvrouwengeesten, de putianas, te temmen, en daardoor ongevaarlijk te maken, dat ze hem tot $\mathrm{djini}$ werden (hij had er dus meer dan één) waardoor hij een specialiteit tot afkeering van dat gevaar werd. Maar die lui hebben al oorspronkelijk een djini, wanneer ze die anderen tot djini temmen, want het is alleen met hulp van de eerste $\mathrm{djini}$ dat men die anderen onderwerpt.

Men spreekt van allerlei landaarden van $\mathrm{djinis.} \mathrm{Papoesche,}$ Maleische, ook wel Europeesche djinis, en elk heeft zijn eigen eisch, dat wil zeggen, als de gomatere danst en hem vereert, moet hij zich zooveel mogelijk aan den djini gelijk maken, zoowel in kleeding als spraak. Sommigen beweren dan ook, dat ze een vreemde taal spreken, maar alleen tijdens het "pitoko».

Ook hoorde ik openbaringen geven in de taal der Tugutils, een stam in het binnenland, in welke taal zij dan ook toegesproken worden. Maar dat is een taal, die elk nogal gemakkelijk een beetje brabbelt. Wat anders is het met Hollandsch natuurlijk. Maar ook, als zoo iemand wat brabbelt en zegt dat het Hollandsch is of Engelsch, gelooft men het wel. Ook hoorde ik van een die een kreupele djini had, en dus daarom alleen met behulp van een stok kon "pitoko». Weer een ander had zelfs een djini van een hert, en bootste het gehuppel van dat dier na.

Maar nogmaals wat is nu een djini?

De geesten van overledenen, zeggen sommigen, die niet behoorlijk verzorgd zijn na hun dood, en dus omzwerven. Daarom heeft men ze van allerlei vreemde volksstammen, omdat die niet 
op de eenig goede Tobeloreesche manier de geest van een afgestorvene weten te verzorgen.

Maar dat komt nu toch niet uit, want hij is de bemiddelaar tusschen de wereld der afgestorvenen en het medium, en moet dus machtiger zijn dan afgestorvenen. Ook worden de zielen van dooden aan djinis in bewaring gegeven. Eén djini kan er zelfs heel veel bewaren. Dat wijst dus ook op geesten machtiger dan de afgestorvenen. Welke? Men denkt ze zich onder zee, heel diep soms, gebonden aan een parelschelp of steen, ook wel oppervlakkiger. Bij het eilandje Kumo lag een stuk rots of steen, een beetje uitstekend, o gola ma doto, die men daar algemeen vereerde als djiniplaats, d. w. z. als plaats waar men een nieuwe djini kon halen, en waar men tot dat doel ook feesten aanrichtte, om ze aldus te lokken. Dat ziet er nu niet uit naar geesten van afgestorvenen. Wel is Tobeloreesch het geloof aan geesten in rotsen en steenen "o gola», en dus zocht men wel die op deze plek. Maar zijn die geesten dan o djini?

Dat het Sjamanisme zich ook met het fetichisme vermengd heeft, blijkt wel daaruit, dat sommige gomateres een fetis hebben, 't liefst een meteoorsteen', die bij hen, die zich niet inlaten met pitoko, een gewone beschermende fetis is, een roehe ma pareta, maar nu bij de gomatere wordt het een fetis waarin zijn djin woont, en die hij in 't water legt, om met dat water menschen te medicineeren, of die hij ook wel gebruikt om regen te maken, door hem in het water te leggen.

Ik ried eens zulk een regenmakende gomatere aan zijn kunst uit te oefenen, omdat door een langdurige droogte veel schade ontstond voor den landbouw. De man bekende mij toen echter, dat hij dat alleen doen kon als uit de dreigende onweerswolken de regen welhaast te voorspellen was.

Naar het me voorkomt behoeven we ons niet te verwonderen, dat de Tobelorees geen antwoord weet te geven op de vraag: wat is een $\mathrm{djini}$ ? Het zijn toch kennelijk wezens, machtiger dan afgestorvenen en ook dan de menschen, dus, de Arabische djins, niets anders. Maar omdat men zulke wezens volstrekt niet kent, er ook in de gewone gedachtengang geen plaats voor heeft, heeft men er wat op gezocht, en dit nieuwe, dat men toch niet begreep, verbonden aan het oude. Dat ze onder zee zijn hier of daar, komt wel uit natuurlijk, maar dat men afgestorvenen of booze geesten met hen op éen lijn wil stellen, is natuurlijk 
absurd. Zoo ook de vermenging met het geloof aan geesten in rotsen of steenen, of wel met het fetichisme.

Dat het sjamanisme zulk een ingang gevonden heeft is niet te verwonderen, niet omdat het de gemeenschap met de geestenwereld, zegge de afgestorvenen tot stand bracht, want daar heeft men ook vroeger wel een weg op geweten, naar 't me voorkomt, maar omdat het door den dienst van deze machtige geesten, hulp beloofde tegen de gevreesde booze geesten, de "tokatas»; omdat het een middel aan de hand deed, om zich de afgestorvenen van 't lijf te houden, waarvoor men bang was. Die hulp heeft men natuurlijk gaarne aanvaard, maar aangezien men omtrent de helpers niet het juiste begrip had, is men gekomen tot de wonderlijke verwarring, die we beschreven hebben.

Bij het behandelen van zieken, plaatst men zich altijd op het standpunt van den Tobelorees, dat de ziekte ontstaat door inwerking van booze geesten, en dus moet de booze geest, en het werk van de booze geesten vernietigd worden, dat spreekt, zonder dat geen genezing. Maar daardoor zijn dan ook de gomateres de geneesheeren bij uitnemendheid geworden, en oefenen zeer vaak een heilloozen invloed uit, waarover men in hoofdstuk 20 "over ziekte en geneesmiddelen». lezen kan.

Wel eigenaardig is de beschouwing van de bovenzinnelijke wereld, die de gomateres er op na houden, en die geheel afwijkt van wat men denkt. Eigenlijk denkt men heelemaal niet over deze dingen na, maar de gomateres zeggen: van deze wereld gescheiden door een gordijn van rook of nevel, is een andere wereld. Waar, dat weet men niet. Eerst heeft men daar de wereld der "tokatas" of booze geesten, vervolgens komt men aan de wereld der $d j i n i s$ en widadaris, en ten laatste bij den Djou of den Heer. Deze woont op de zevende verdieping, en deze verdieping is afgesloten met zeven deuren, en daarin kunnen alleen de allersterkste gomateres doordringen. Ook de aarde bestaat uit zeven lagen.

Dit nu wordt ook elders geloofd, maar elke g o matere geeft er zijn eigen uitlegging bij. De een deelde mij mede, dat men altijd tot den $\mathrm{Djou}$ moest gaan om de medicijn voor den kranke, men ging alleen, doch reeds onderweg komt men iemand tegen, die belet verder te gaan, doch de medicijn medebrengt, die de gomatere dan mee terug neemt naar de aarde.

Een ander vertelde, dat ze naar boven ging naar den $\mathrm{Dj}$ ou, 
maar daar heel moeilijk binnen kon komen, omdat er altijd veel wachters voor de deur stonden. Men moest dus probeeren'door het een of andere achterdeurtje naar binnen te sluipen, en den $\mathrm{Djou}$ stilletjes te naderen. Deze zat aan een groote tafel, met voor zich op die tafel een reusachtige schotel waarin alle zielen (waarschijnlijk de gestorvenen). $\mathrm{Z}_{\mathrm{ij}}$ moest den Heer nu vragen om de ziel dergene die ziek was, zoo die reeds op de schaal lag. De Heer neemt dan, ingeval de zieke nog weer beter kan worden, de ziel op, en gooit hem aan den gomatere toe, die er mee naar beneden gaat, en hem aldus terugbrengt in den zieke.

Weer een ander maakte haar heele familie onrustig, want ze had boven bij den Heer zijnde, daar haar kleinzoon gezien, die voor den Heer vuur haalde om zijn strootje aan te steken (een bezigheid die kleine jongens ook op aarde wel voor hun ouders verrichten), en nu was het vast en zeker uitgemaakt, dat ook dat kind sterven moest.

Dat alles bij elkaar, hoe Indonesisch ook, vormt toch een soort van leer, die zich al heel moeilijk rijmen laat, met het Tobeloreesche geloof, omtrent het leven na den dood, zooals wij dat zien zullen in hoofdst. 22. Immers dan zijn het booze geesten die de levenskracht opeten, en tengevolge van het ontbreken van levenskracht (gurumini) treedt de dood in. Hier echter treedt beslist een hoogere macht op, de $\mathrm{Djou}$ die de zielen (o njawa) tot zich neemt, over hun lot beschikt enz.

En hierin is het sjamanisme zelfs met zichzelf geducht in tegenspraak, want in aanpassing aan het geloof der Tobeloreezen, heeft de djini een bewaarplaats voor de zielen; daarheen worden ze gebracht, dadelijk na den dood verblijven ze daar. Dat nu is niet te rijmen met het verblijf der zielen bij den $\mathrm{Djou}$ in den hemel; wij zouden zeggen, het een of het ander is onwaar, maar zoover denkt men niet. Men heeft eenvoudig de meeningen die niet bij elkaar passen, naast elkaar, en bekommert zich er niet over, dat de een den ander uitsluit. Dat is alleen te verklaren daaruit, dat het Sjamanisme, dat op zich zelf eigenlijk een stelsel is, gekomen is tot een volk dat al een cultuur had, en zich daar tusschen in heeft gewrongen, waaruit een verwarring ontstaan is, zoo groot, dat men nu niet meer weet te zeggen hoe het oorspronkelijk geweest is. $N u$ is het geheele denken van het volk door het Sjamanisme beinvloed, zoodat men de gebruiken en termen daarvan heeft overgenomen, ook al is alles al heel onlogisch. Di. 77. 
Men heeft nu b.v. ook, dat iemand die zwaar ziek is (of heet) zich het leven verlengt krijgt, doordien de gomatere boven voor hem nieuwe levenskracht, nieuwe gurumini gaat halen. Maar dat is heelemaal in tegenspraak met het feit, dat het «jenseits» de plaats niet is voor de levenskracht, en dat degenen die daar zijn, zoo ze niet als dilikini levenskracht medenamen van de barmhartigheden der levenden af hangen, opdat die hen daarmede voorzien zouden.

Dat men vroeger het Sjamanisme niet gekend heeft, stemt men algemeen toe. De geesten openbaarden zich toen in den een of ander, bij het gaan in den strijd b.v., zonder eenige voorbereiding. Dat was dus nog rein fetichisme, want men had de fetischen bij zich.

Waar wij er meermalen op wijzen, dat bij genezingen b.v. het animistisch standpunt, omtrent de kracht van planten etc. als toevoerders van levenskracht, niet meer ingenomen wordt, bedenke men, dat hierdoor volstrekt niet bewezen wordt, dat men dit standpunt oorspronkelijk niet innam, maar alleen dat het Sjamanisme veel van het oude in onbruik heeft doen geraken.

Een moeilijke tijd komt voor den gomatere, als zijn geneeskundige kuren, herhaaldelijk mislukken, en zijn patienten sterven. Hij wordt er dan van verdacht, dat zijn djini, inplaats van een helpende, een verdervende kracht is geworden, een "tokata». Dan gaat men met heel veel ophef den $\mathrm{djini}$ baden, 'tgeen men gewoonlijk aanduidt met de Galelareesche uitdrukking: o djini ha tiodo. Het voornaamste hiervan is wel, dat allen die of als meester of als leerling aan de djini verbonden zijn, in processie, al dansende naar het strand gaan, waar dan de gomatere zich baadt, ook nog wel andere ceremoniën verricht, waarna men weer dansende terugkeert. Baat ook dat alles niet, blijft de gomatere toch ongelukkig in zijn praktijk, dan komt hij in levensgevaar, want men beschouwt hem nu als gevaarlijk, en niet zelden wordt nu een moord gepleegd, om van hem af te komen. Het schijnt dat de lieden uit zijn omgeving dan bij onderlinge afspraak, iemand aanwijzen om hem te dooden, waarna de persoon heel kalm in zijn huis doodgeschoten wordt. De moordenaar of moordenaars zijn dan onvindbaar. Niemand doet eenige aanwijzingen, hoewel het dikwijls heel duidelijk is, dat elk ongeveer de zaak moet weten. Men beschouwt dit eenvoudig niet als moord, het is de maatschappij van een vampyr verlossen. 
Vraagt men nu, welken invloed dit Sjamanisme heeft op de maatschappij als zoodanig, dan moet het antwoord beslist luiden: een zeer schadelijke. Immers, hier is nu een klasse van menschen, door hun vermeende bovennatuurlijke krachten, deels geeerd, deels gevreesd, die er een groot materieel belang bij heeft, dat alles bij het oude blijft, en als zoodanig dus ook vijanden zijn van alle vooruitgang. Alles wat lijkt op ontwikkeling, wordt door hen tegengestaan, in kras egoisme houden ze alles tegen wat hen zou kunnen benadeelen, en zij zijn heusch niet kieskeurig in hunne middelen.

Ik werd eens in het heidensche dorp Gorua te hulp geroepen door een jongen man, daar de gomateres zijn zuster al lang zonder baat behandeld hadden. Of ik nu niet mijne hulp wilde verleenen? Het arme schepsel was er treurig aan toe, zij leed aan verlamming. Ik gaf medicijnen en onder Gods zegen hielpen die. Kon de vrouw eerst alleen het hoofd nog maar bewegen, langzamerhand ging het vooruit, tot zij zelfs weer zitten kon. Groote blijdschap natuurlijk bij haar broeder die mij geroepen had. Maar, helaas, op zekeren dag staat de arme kerel voor me, de flesch met medicijn in de hand. Wat scheelt er aan? Is je zuster erger geworden? Neen Mijnheer, maar ze durft de medicijn niet meer gebruiken. Waarom niet? Het hielp toch goed! Ja Mijnheer, dat is het juist.

Het lange verhaal dat ik nu te hooren kreeg kwam hierop neer, dat de gomateres uit de kampong mijn medicineeren met leede oogen gezien hadden, want, hielp het hier zoo goed, dan zouden ook wel andere zieken bij mij komen, en dat was schadelijk. Ze waren dus te rade gegaan met de voorouders der zieke vrouw, en dezen hadden medegedeeld, dat zij heel boos waren over mijn komst, en indien de vrouw beter wou worden door mijn medicijnen moest ze het zelf weten, maar dan zou de heele familie uitsterven!

Gevolg, de arme vrouw durfde niet meer drinken van de medicijnen. Haar broeder vertelde het me met tranen in de oogen. Na twee weken was ze nu dood.

Ik zou dit geval met nog heel vele kunnen vermeerderen. Heel wat maatregelen door het Binnenlandsch Bestuur genomen, mislukken ook, omdat de gomateres het gevaarlijke nieuwigheden vinden, en dus achter de schermen stoken.

Tijdens een pokken-epidemie beweerden zij, dat de geesten tegen 
de vaccine waren, en toen tengevolge daarvan, de menschen die zich niet lieten inenten in massa stierven, gelastten zij de huizen af te breken, want de menschen stierven door «tokatas" die uit den grond kwamen.

Over het geheel kan men hun geen anderen naam geven dan "bedriegers», hoewel er wellicht ook een enkele onder is, die werkelijk in hallucinaties meent te zien, wat hij beweert te zien. Een vrouwelijke gomatere vroeg mij eens op verbaasden toon, toen ik beweerde dat al die geestenpraatjes maar bedrog waren: wat ze dan zag als ze in slaap was? Dewijl zij kennelijk eerlijk was, werd door haar vraag bewezen, dat zij werkelijk iets $z a g$.

Men moet natuurlijk altijd voorzichtig zijn bij het beoordeelen van zulke menschen. Velen zijn eenvoudig bedriegers, die maar van de goedgeloovigheid der menschen gebruik maken, om hen van alles voor te praten; anderen zijn behendige goochelaars, die b.v.b. hun patienten uit pijnlijke plaatsen in het lichaam allerlei tevoorschijn weten te tooveren, stukjes bamboe, stukjes glas; zelfs insecten; anderen weer zijn gevaarlijke giftmengers, of maken van hun overwicht gebruik om menschen te suggereeren.

Ik zag eens een kamponghoofd ziek worden en sterven, zonder dat éénig bepaald ziekteverschijnsel op te merken was. Alleen werd de man van dag tot dag zwakker. Toen hij dood was en ik mijn verwondering uitsprak over dat raadselachtige sterven, vroeg zijn zoon mij : maar zeet Mijnheer het dan niet? Wat? Wel, gomatere die, en hij noemde een beruchten naam, heeft hem dood gemaakt. Hoe dan? Wel, ze hadden twist over een stuk grond, en toen heeft de gomatere gezegd, dat hij wat voor hem klaar maken zou, en dat hij dien en dien dag niet zou overleven. $\mathrm{En}$, zoo mijnheer weet, hij is ook vóor dien dag gestorven.

Het dooden van iemand op die manier noemt men: manga manarama ha diai: iemands werk maken. Men gelooft daar helaas heel stellig aan.

Dezelfde go matere, die dit uitgehaald had, ontmoette ik eens in nogal groot gezelschap, waaronder ook heel wat van zijn vereerders.

Daar we nu in gesprek met elkaar kwamen, bood ik den man een weddenschap aan. Hij mocht voor mij zijn werk maken, en was hij in staat mij ook maar hoofdpijn te bezorgen, dan zou ik hem een som geld geven. Het was werkelijk lastig voor den man, want zijn aanzien stond op 't spel, zoo hij zijn onmacht bekende. Dat deed hij dan ook niet, maar hij redde zich er 
heel slim uit, door te antwoorden: dat kunt $U$ gemakkelijk zeggen mijnheer, want $u$ weet wel dat alle Tobeloreezen zooveel van $\mathrm{u}$ houden, dat noch ik, noch iemand anders, $\mathrm{u}$ ooit eenig kwaad zou willen toebrengen. Een luid toestemmend gejuich bewees, dat ik den gomatere niet gevangen had. Later wist een civiel-gezaghebber hem een vergiftiging te bewijzen, waarna hij tot dwangarbeid veroordeeld werd, en naar Merauke (N. Guinea) gebracht. Vandaar keerde hij, na het verstrijken van zijn straftijd terug, en toen bleek, dat dit alles zijn aanzien bij zijn heidensche landgenoten volstrekt niet geschaad had, hij was nog populairder dan te voren, en onderwees zijn publiek door te zeggen: daar ik onschuldig was ben ik teruggekomen. Ik ben in Holland geweest, en daar heeft me de Koningin gezien. $\mathrm{Z}$ ij bekeek me door een langen kijker, en zei toen: die man is onschuldig, en daarom hebben ze me weer losgelaten. Al deze onzin werd maar goedgeloovig geslikt, want $n u$ zou zeker niemand meer zich zijn toorn op den hals durven halen, door te zeggen dat hij loog. Niettegenstaande dit alles moet men toch erkennen, dat ook sommigen van deze menschen wel bedrogenen maar nog geen bedriegers zijn. $\mathrm{Zij}$ zijn opgevoed in deze gedachtenkring, hebben het van klein af aldus gezien, en zijn zij dus wat zenuwachtig van aanleg, dan komen ze er zoo gemakkelijk toe, te meenen dat ze openbaringen van geesten hebben. Voorzichtigheid bij het beoordeelen van cle verschillende personen is in dezen dus wel aanbevolen.

Het sjamanisme is hoogstwaarschijnlijk over Ternate tot de Tobeloreezen gekomen; dit valt op te maken uit de meerendeels Ternataansche uitdrukkingen die men bezigt bij de geestenklopperij. En dat het, als Mohammedaansch verschijnsel, b. v. door het verbod van het eten van varkensvleesch, voorbereidend werkt voor den Islam, is ook wel heel zeker.

\section{HOOFDSTUK 13.}

\section{Feesten.}

De Tobelorees houdt veel van feesten. Alles wordt hem tot een feest, zonder feest laat zich niets denken of doen.

Bij huisbouw, landbouw, godsdienst, trouwen, begraven, het is altijd feest en nog eens feest, en behalve de officieele, maakt 
men er nog heel wat "zoo maar» bij, zonder eenige bepaalde aanleiding, of met een gezochte aanleiding, echter allen uit lust om feest te vieren.

Bij allerlei gelegenheden ontmoeten wij een feest, en dus deelen wij eerst kortelijks mede, waaruit een feest bestaat.

Volgens den gewonen gang van zaken, komt men in den namiddag. bij elkaar. De feestgever zelf heeft dan gezorgd voor het eerste maal voor de gasten.

Vrouwen en mannen zitten daarbij apart en eten niet gezamenlijk, tenminste, dat is de gewoonte niet, hoewel ik toch ook wel gezien heb, dat men gewoon door elkaar zati Voor de noodige lokaliteit heeft ook de feestgever gezorgd, dus zijn aandeel aan het feest is niet gering.

Echter, is het hoofdmaal genuttigd, dan is daarmede het eten en drinken niet geeindigd, want elk der gasten heeft voor zich een schotel met spijze meegebracht. Die spijze is van allerlei: een schotel met visch, rijst met wat toespijs, kortom, alles wat de Tobeloreesche mond maar lekker vindt. Na den hoofdmaaltijd neemt elk zijn schotel op de hand, en men begint nu te $\mathrm{maka-}$ tana, d.w. z.: men loopt door elkaar, heeft allerlei pret, en waar twee lieden elkaar ontmoeten die een praatje willen maken met elkaar, stopt elk den ander wat van den inhoud van zijn schotel in den mond. Niet veel, och neen, het is maar voor de vriendschap of de gezelligheid, maar op die manier blijft men aan den gang. Raakt den een of den ander zijn schotel wat gauw leeg, dan gaat hij nog wel weer naar huis om nog wat te halen, maar gewoonlijk is één schotel voldoende, om het den nacht door vol te houden.

Anderen hebben palmwijn bij zich, en schenken ieder een beetje daarvan, en zoo gaat het, maar steeds presenteerende en toestoppende, voort. Wie moe wordt, gaat wat op de bank zitten, met zijn schotel naast zich, om wat mee te zingen of voor den dorst een grooter glas palmwijn te drinken, totdat hij, straks weer wat uitgerust, zijn rondwandeling tusschen de andere gasten weer begint. - Het is een zonderling gebruik. Men eet den heelen tijd door. Dat men daardoor toch niet te veel krijgt is me meermalen verzekerd door menschen die 's morgens hongerig thuis kwamen, en gauw een paar pisangs roosterden, om hun honger te stillen, voor ze zich te slapen legden. Natuurlijk is het naar ons idee niet heel appetijtelijk, dat elk met vuile 
vingers in zijn schotel tast, en het dan in iemands mond steekt, maar daar voelt de Tobelorees niets van. De heele atmosfeer van het feest brengt hem in een hoogst behagelijke stemming.

Bij kleinere feesten heeft dit elkaar te eten geven, niet plaats, alleen bij de grootere.

Als muziekinstrumenten heeft men trommen o damono, en metalen bekken, gongs "o lih a ng a" geheeten, die men tezamen klopt, zoodat het een, soms wel niet onaangename, maar op den duur vreeslijk vervelende, en bovenal oorverscheurende muziek geeft. Men vindt dit echter heerlijk, en smaken verschillen.

De trommen zijn uitgeholde boomstammen, aan eene zijde met een hertenhuid bespannen. Men heeft die in alle grootten, tot een halve manshoogte toe.

Voor ontspanning dient voornamelijk de krijgsdans : ho hola. De trommen worden daarbij geslagen in een vlug tempo, met twee stokken, een soort roffel (ho hulatera) en men vangt den dans aan. Men heeft daartoe noodig een lans en een schild, ook wel nog bovendien een kapmes. Bij den aanvang, als de feeststemming zoo hoog gekomen is, zet de feestgever deze voorwerpen voor een der gasten, zoo mogelijk de aanzienlijkste, neer, of wel hij opent zelf den dans, waarbij hij na afloop schild en lans voor een ander neerzet ( $\mathrm{ha} \mathrm{a} \mathrm{ka)} \mathrm{die} \mathrm{daarmede} \mathrm{officieel}$ tot dansen uitgenoodigd is. Het is dus bijna altijd een solo-dans, alleen bij bijzonder groote feesten, of ook wel om een aankomende geëerde gast tegemoet te gaan, dansen meerdere personen tegelijk. De dans bestaat feitelijk uit niets dan het aannemen van de verschillende standen, die in een gevecht van man tegen man voorkomen kunnen. De danser staat in den geest tegenover zijn tegenpartij, die hij door allerlei sprongen tracht af te matten, door vreeselijke gezichten te trekken aan het lachen zoekt te brengen, door stof in zijn richting op te doen stuiven tracht te verblinden, enz. De mooiste, en het meest toegejuichte dans, is in ons oog nog lang de sierlijkste niet. Hoe langer de danser het weet uit te houden - en deze vlugge bewegingen zijn natuurlijk zeer vermoeiend - hoe meer triomfgeschreeuw opgaat. De schoondochters uit de familie beginnen om hem heen te dansen, met korte pasjes, al met de handen klappend onder het uitstooten van aanmoedigende kreten, in vervoering loopt iemand naar hem toe met een geweer, en schiet het boven zijn hoofd af, de gastheer, zichzelf niet meer van verrukking, neemt een mooie 
schotel, en zet die neer als belooning voor den danser! Het tooneel is een en al opwinding! Straks kan de danser niet meer, en zet lans en schild voor een ander neer, terwijl hijzelf, overdekt met roem, zweet en stof, op de kokiroba, de groote bank vóór het huis neervalt, om zich met een glas palmwijn schadeloos te stellen voor de inspanning.

En zoo gaat het soms uren achtereen, of ook wel, tot elk zoowat gedanst heeft, en niemand meer uitkomt, elk de eer afwijst, dan komt het feest in rustiger tempo, en men zet zich neer, of begint met elkaar eten te geven, terwijl de trom langzamer klinkt, tot misschien straks de geestdrift weer uitbarst in hola.

Dat geven van mooie schotels, zou den gastheer gemakkelijk ruïneeren, maar het is nogal niet heel gevaarlijk, aangezien de adat bepaalt, met hoeveel centen elk stuk weer ingelost kan worden. Hoogstens is dat een cent of tien. Met een paar gulden, kan men zich dus nog al wat vrijgevigheid op dit gebied veroorloven.

Bij de doodenfeesten heeft men nog een andere dans, eigenlijk voor de vrouwen, ho hare ne geheeten. Men legt daartoe, op eenigen afstand van elkaar twee sagobladsteelen "o utongo" op den grond. Voor elk gaat een persoon zitten, die de uiteinden van twee andere steelen vasthoudt, dwars over de eerste heengelegd. Men houdt die zoowat een halve voet van elkaar af, en begint nu, op de maat van de trom, deze steelen gezamenlijk eerst tweemaal op de onderliggende steelen te slaan, en daarna ééns tegen elkaar aan. De danseres moet nu tusschen de steelen dansen, met vluggen voet, want is ze niet vlug, dan treffen de bij drie tegen elkaar slaande steelen haar voet of enkel, hetgeen terstond hoorbaar is, daar dan de klank der steelen niet gehoord wordt. De danseres is gewoonlijk half als man opgetooid, en heeft niet zelden een oud geweer in de hand, terwijl ze onder het dansen onafgebroken gillende kreten slaakt.

Dat is een soort verpoozing tusschen het hola op de doodenfeesten.

De Tobeloreesche zang is het $1 \overline{\mathrm{e}}-1 \overline{\mathrm{e}}$, ook kortweg o gule: het spel geheeten. Oorspronkelijk is dat de eenige zang geweest, die men gekend heeft. Het zingen is maar een eentonig zangerig reciteeren, waarbij sommige maten en toonen lang aangehouden worden. Het is vọor onze ooren altijd nog al moeielijk te ver- 
staan wat men zingt, om reden men het zóó verdraait en verbasterd, dat men er niets van te maken weet.

Voor de woorden van de zangen, zie men het hoofdstuk daarover (35).

Deze $1 \overline{\mathrm{e}}-1 \overline{\mathrm{e}}$ heeft het groote voordeel geen beurtzang te zijn; al is ook de inhoud gewoonlijk sterk erotisch, het geeft toch niet tot onzedelijkheid aanleiding. Gewoonlijk zingt de een de tekst voor, en de anderen herhalen die, of zingen het refrein. Het is natuurlijk, dat dit bij een halfdronken troep een afschuwelijk gelal wordt, waarbij men wee wordt om het hart, alleen van het aanhooren. En het gaat uren achtereen door.

Dit betrekkelijk onschuldig karakter, kan men niet meer zoo sterk toezeggen, aan het $n u$ ook zeer geliefde dopa-dopa en ronga-ronga. Beide zijn beurtzangen tusschen mannen en vrouwen, sterk erotisch gekleurd over het geheel. Toch, de officieele teksten zouden het hem nog wel niet doen, maar men zingt deze zangen gaarne op kleinere bijeenkomsten en feesten, waar het wat minder officieel toegaat, en laat daarbij dan de eigen dichtader ongestoord vloeien, en helaas, het gevolg daaruan is dikwerf het plegen van onzedelijkheid. De lusten, die door het elkaar toezingen opgewekt zijn, worden dikwerf in den duisteren nacht meteen bevredigd. Heel veel goeds kan dus daarvan niet gezegd worden.

Van al dat soort zangen zijn de woorden dikwerf niet heel veel van elkaar verschillend, het verschil zit maar in de maat en den slag der trom waarop men zingt. Bij bijzonder vroolijke partijen zingt men ook nog wel o dopa-dopa-gila, o djoma, en o djore-djore, dit alles geen beurtzangen, maar algemeen bekend zijn die in Tobelo niet, meer nog in het Kausche en Dodingasche. Wat bijzonders is het nog met het o wela-wela, het z.g.n. touwtje trekken. Dit spel is een aanhangsel van het Galelareesche doodenfeest, dus beslist niet Tobeloreesch. Toch houdt men er heel veel van, voornamelijk de meer lichtzinnigen, en tracht op allerlei wijze het recht te zoeken, dit spel te mogen spelen. Het heette, dat de kampong $\mathrm{Gura}$ daartoe het recht gekocht had, van het districtshoofd van Galela, en dat die kampong het daarom mocht spelen. Anderen, niet tot die kampong behoorende, weten bij een doodenfeest uit te rekenen, dat de doode nog een weinig Galelareesch bloed in zich had en men dus verplicht is, hem ook Galelareesch te eeren met 
dit spel. Nog weer een ander deed me het volgend verhaal, om het goed recht der Tobeloreezen in dezen te bewijzen.

Toen de koning van Tolo op aarde zou verschijnen, was het een maand lang donker. Daarna kwam hij als een widadari (nimf) uit den hemel, in een zweefpaleis. Hij daalde neer aan de kaap Luari - de Noordelijkste punt van het district Tobelo en bouwde daar zijn fort Baluari. Hij was de stamvader van het Galelareesche districtshoofd Pakawani, en het Tobeloreesche Hoofd: Ngofa manjira Fola-ngara. Hij bouwde een stad te Medee, Tofongo geheeten, en breidde zijn kampong uit tot Bobulutu ma doto - een uur Zuidelijker. Hij was Christen, en had vier Pendetas en 14 Goeroes. De Sultan van Ternate kwam hem beoorlogen, maar gedurende tientallen van jaren te vergeefs. Toen kwam er een vreeselijk Ternataansch krijgsoverste: Laha bati ma tato geheeten, die na drie jaren door zijn bezweringen de "Dukono" deed ontstaan. Dit is de vulkaan "Tolo geheeten, gelegen in het Tobelosche, achter de plaats waar het oude Tolo lag. Dat de ondergang van dat rijk met een uitbarsting van den vulkaan saam viel, is wel waarschijnlijk.

De koning van Tolo deed echter ook bezweringen, waardoor de uitbarsting nog een paar jaar tegengehouden werd.

Toen deed zijn zuster Prinses Babola een bezwering en zeide:

Tolo dai, ngori dia: (als Tolo zeewaartsch (is), ik landwaartsch.

Tolo dia, ngori dai Tolo landwaarts, ik zeewaartsch, en daardoor barstte de berg uit. De koning is echter daardoor niet verloren gegaan, maar achteruitloopende, gegaan naar Tolo-nuu (het eiland van Tolo, zoowat een half uur zeewaartsch gelegen) en vandaar naar den hemel.

$\mathrm{Zijn}$ graf is nog een vereenigingsplaats op het eiland Tolo-nuu.

Zijn zuster is overgevlogen naar Tolo-fuo. - Dit ligt op de Westkust; het woord beteekent: kind van Tolo. - Daar zat zij in een klapperboom, en wat men ook deed; ze wilde er niet uit komen, niettegenstaande men allerlei spelletjes speelde om haar te lokken. De Sultan van Ternate, die van het geval hoorde, gelastte toen te wela-wela. Daarop pas kwam ze naar beneden. Ziet $U$, zeide mijn zegsman, wela-wela is dus van Galela en Tobelo samen, want het komt van Tolo, dat midden tusschen beiden in lag. De Prinses Bobola ging heen en stichtte Dodinga. 
Niettegenstaande dit verhaal, is men algemeen wel de meening toegedaan, dat wela-wela niet Tobeloreesch is. De tekst kan men hierachter lezen. Het is niet erotischer dan andere spelen, maar het is een beurtzang, waarbij steeds de jongens voorzingen, en de meisjes of vrouwen elken regel beantwoorden, met de vier laatste lettergrepen te herhalen, gevolgd door: wela-wela. Men houdt tezamen een nogal lang touw vast, een liaan, mannen en vrouwen, elk aan een eind. De trom gaat, men loopt of slingert voorloopig al zingende heen en weer, maar tegen dat de zang op het eind loopt, wordt de maat van de trom sneller, men pakt het touw vaster aan, beide partijen naderen elkander steeds meer, en straks trekt men werkelijk van weerskanten aan het touw, heen en weer rukkende, met het gevolg dikwerf, dat de heele troep over elkaar heen valt.

Dit alles in het duister van den nacht, hoogstens bij lichte maan, verhitte gedachten, opgewonden jongelui, men vrage wat het gevolg is van dit op een kluwen door elkaar rollen! Menig meisje wordt daardoor zwanger, en krijgt een wela-wela-kind, d.w.z. een kind waarvan de vader niet aan te wijzen is, omdat het meisje met velen gemeenschap gehad heeft.

Dat men dit spel gaarne speelt is geen wonder, ik heb zelfs een Controleur. gekend die heel gaarne meedeed.

Hoewel het nu niet te misprijzen is, dat een volk, geplaatst in een land en in een natuur, die niet al te veel inspanning vorderen, om nog een aangenaam leven mogelijk te maken, vroolijk is, en van feesten houdt, heeft het al te overvloedige ook nogal zijn schaduwzijden. Want voor een maatschappij als de Tobeloreesche, zijn de vele feesten een ernstig beletsel om vooruit te komen. Alleen toch voor de grootere feesten, die men als fatsoenlijk man wel meemaken moet, heeft men zeker wel haast een derde van het jaar noodig, niet alleen met de feesten zelf, maar ook met de voorbereidselen daartoe, het aanschaffen van wat noodig is enz. En het kost veel geld, dat is natuurlijk. Waarbij nog komt dat uit een vlijtige feestganger, al heel gemakkelijk een gewoonheidsdrinker wordt. Een soort menschen, dat wel niet meer dronken wordt, en onmogelijke hoeveelheden palmwijn kan verstuwen, maar ook ganschelijk verslapt, zonder palmwijn niet meer leven kan, en met palmwijn voor niet veel meer te gebruiken is. 


\section{HOOFDSTUK 14.}

\section{Zwangerschap en geboorte.}

De voorschriften omtrent hetgeen de vrouw tijdens de zwangerschap in acht te nemen heeft, zijn heel verschillend, zooals dat ook wel niet anders kan bij een stam, die zoozeer verspreid woont als de Tobeloreezen. Wij geven echter zooveel mogelijk alles wat wij vonden.

Van elk voorschrift geldt dus echter, dat sommigen het opvolgen.

Wanneer de vrouw zich baadt, moet ze zich het lichaam niet afwrijven met cocosnoten-melk alleen, zooals men dat anders doet, maar men moet in de cocosnoten-melk uitwringen allerlei slijmerige bladeren, opdat daardoor de bevalling voorspoedig zij. Klaarblijkelijk wordt hier gedacht aan een sympathiemiddel, om het heet en droog worden der vulva tijdens de partes te voorkomen.

Algemeen is men van oordeel, dat de vrouw voorzichtig moet zijn, om niet te vallen, niet in boomen te klimmen, of over boomen te klimmen, opdat ze geen ongeluk zou krijgen.

Om diezelfde reden vindt men ook, algemeen, dat de man zijn vrouw tijdens de zwangerschap niet mag slaan, huewel sommigen dat nog verzwakken met: hij mag haar niet in of op den rug slaan.

Omtrent het werken tijdens de zwangerschap, zijn de gevoelens verdeeld. Sommigen beweren: ze moet zwaar werken, opdat de bevalling goed verloope, maar anderen keuren zwaar werk beslist af. Wel moet ze werken zeggen die, maar niet al te zwaar, en haar man moet haar bijstaan. Ook zijn er die zeggen: ze mag wel tuinarbeid verrichten, maar geen hout kloven, opdat haar kind niet met gekloofden schedel geboren worde.

In tegenspraak daarmede is echter weer, dat men tamelijk algemeen verwacht, dat de vrouw zelf zorgt, vóór haar bevalling, een goede portie brandhout in voorraad te hebben, opdat ze het direct na de bevalling niet al te druk hebbe.

Volgens den een mag ze heelemaal geen vruchten eten, maar volgens anderen bepaalt zich dat verbod alleen tot cocosnoten, kanarienoten en suikerriet. Ook worden eieren tamelijk algemeen verboden, opdat het kind niet "vuil» worde. Hierbij wordt dus wel gedacht aan spijzen die er ò zooals eieren, vuil uitzien, of wel, na gebruik diarrhae veroorzaken. 
Verder wordt nog verboden het eten van een zeker schelpdier "o ritama» geheeten, kennelijk, omdat dit woord beteekent: kippenvel hebben, en men dit, of misschien ook "koorts» vreest voor het kind, want het woord is een vervangwoord voor »koude koorts».

Verder mag zij geen "o gurita», poliepen eten, natuurlijk opdat haar vrucht bij de bevalling niet als met polypenarmen vastgehouden worde. Ook wordt nog verboden te eten o bikuduhu, een mij onbekende krab. Verder is, volgens sommigen verboden te eten: varkensvleesch, schildpadvleesch, giftige visch (visch wier rugvinnen voorzien zijn van giftige stekels) geep, en nog andere vischsoorten. Volgens anderen zijn dit de gewone verboden spijzen, als de vrouw gemedicineerd wordt. Dit medicineeren heeft tijdens bijna elke zwangerschap plaats, en daarom zegt men dan maar dadelijk; dat al deze spijzen verboden zijn. Nog wordt verboden om veel scherpe of sterke dranken te drinken, en aangeraden veel zuur te eten, opdat het kind blank zij.

De vrouw moet zorgen steeds met de noodige amuletten, o bobarehe, behangen te zijn, opdat haar kind niet aangevallen worde door een booze geest: o sjethan, en om dezelfde reden is het ook niet gewenscht dat zij alleen in het bosch loope, omdat daar de gewone verblijfplaats der $\mathrm{Sjethans}$ is. Het is ook met het oog op "booze geesten", dat zij zich moet laten medicineeren, want bij het minste wat zij maar voelt, of zelfs als ze maar iets ongewoons droomt, wordt gedacht aan booze invloeden, en nu moet er dadelijk onderzocht worden door middel van waarzeggen of door hulp van een gomatere of er geen booze machten aan het werk zijn.

Natuurlijk is dit bijna altijd het geval, en zij moet dus gemedicineerd worden, waarbij de straks genoemde verboden, in werking treden, zoo men ten minste die niet al reeds vroeger gehouden heeft.

De vrouw mag geen beesten pijnigen (redenen niet opgegeven), haar haar niet knippen - dat is heel logisch, want ze zou daardoor zichzelf van een deel gurumini berooven, en dus verzwakken; ze mag niet voor een open deur zitten, of water drinken uit een kokosnootdop (anders een heel gewone drinknap), ook niet zitten in een tatapa, (groote platte mand) opdat haar kind geen overmatig groot aangezicht hebbe.

Zit de vrouw, dan mag men haar niet aan het schrikken 
maken, want haar kind zou dan geboren kunnen worden met een onvolledig lichaam.

Ook mag men achter haar rug niet hakken of krijgsdansen, want haar kind zou dan met een gespleten mond geboren kunnen worden.

Hoewel niet heel algemeen meer, vindt men toch nog wel sporen ervan, dat men zich oorspronkelijk de man der zwangere, gedacht heeft als ook onder den invloed der zwangerschap. Dit blijkt wel uit het volgende, dat ik nog daaromtrent vond:

De man eener zwangere vrouw, mag bij het "bore», het bedwelmen van visch, om die daarna gemakkelijk te bemachtigen, niet de bore, het bedwelmingsmiddel, vasthouden, want het zou daardoor aan kracht verliezen, en de visch zou niet bedwelmd raken.

Ook mag hij geen sagoeboom omhakken, want daardoor zou de sagoe uit de boom verdwijnen. - Hieruit blijkt wel, dat men zich hem denkt, als zeer ongunstig beinvloed.

Hij mag zijn vrouw tijdens de zwangerschap niet zien, want dat vermeerdert zeer de smart der vrouw tijdens de bevalling. Hij moet zich dus verwijderen. Inderdaad ziet men ook nog heel veel, bij Heidenen vooral, maar toch ook wel bij christenen, dat de man zoodra hij weet, dat zijn vrouw zwanger is, op reis gaat, z.g.n. om geld te zoeken, en eerst terugkeert nadat zijn vrouw bevallen is. Dat de man, ook al is hij tijdens de zwangerschap thuis gebleven zich tegen de bevalling verwijdert, heb ik meermalen opgemerkt.

Een eigenlijke reden gaf men daar niet voor op, maar vermoedelijk vreest men, zoowel voor den man als voor de vrouw, een ongunstigen invloed.

Wordt de vrouw tijdens haar zwangerschap gemedicineerd, dan worden aan den man, indien hij aanwezig is, ook een deel der verbodsbepalingen opgelegd.

Tijdens de zwangerschap der vrouw, mag de man geen prauw maken of een regelhuis. Men zegt: het kind zou dan met moeite geboren worden, maar ik veronderstel, dat het wel wezen zal, omdat èn aan het maken van een prauw, èn aan het bouwen van een huis zooveel vast is, dat het niet gedaan mag worden door door iemand die ongunstig beinvloed is.

Ook rechtstreekschen invloed op het kind schrijft men aan den vader toe, want deze mag geen dieren plagen of stelen, opdat het kind niet wreed zij of diefachtig. 
Hij mag geen kleine vischjes schrappen met zijn nagel (de gewone manier) en ook geen visch schrappen achter den rug van zijn vrouw, want het kind zou daardoor geboren worden met een gescheurden lip.

Ook mag hij zich geen touw om de hand binden. Misschien vreest men daardoor voor de vrucht een omstrengeling met de navelstreng.

Bij de bevalling zit de vrouw, gewoonlijk, gehurkt op een stuk hout, met den rug steunend tegen de slaapbank, of tegen een paal van het huis. Bepaalde deskundigen heeft men niet, en gewoonlijk loopt de bevalling goed af.

Gaat het niet goed, dan roept men gomateres die de invloed der booze geesten moeten verbannen. Men ziet dan allerlei offers staan die door die verschillende medicijnmannen verordend zijn. Is er eenig mechanisch beletsel, dan helpt dit alles natuurlijk niet, en het arme schepsel staat een vreeselijk lijden te wachten, want de behandeling die zij dan ondergaat, is gewoonlijk slechts een grove mishandeling; maar het is ook mogelijk dat de bevalling tegen gehouden wordt door zenuwachtigheid der vrouw, etc., en nu helpt misschien het gemurmel van den toovenaar en het is heel natuurlijk dat men, waar men toch meermalen gunstige gevolgen ziet, op deze hulp blijft vertrouwen.

Van eenige mechanische hulp bij de baring is natuurlijk nooit sprake. Men vindt dit eenvoudig vreeselijk. Ik herinner me, dat men mij eens riep bij een vrouw die al dagen lang lag, ik geloof met een tweelingsbevalling, zonder dat er eenige vooruitgang kwam. Ik begreep later, dat ik geroepen was door familieleden, en niet op verlangen van de vrouw zelf. Ik moest natuurlijk toucheeren, maar toen de vrouw dat merkte, riep ze op zoo'n angstigen toon tot haar omgeving: wat zal er nu met me gebeuren, zal hij zijn hand in mijn lichaam brengen (han gaini)?, dat ik er maar van afzag, en me er toe bepaalde eenige aanwijzingen te geven, en wat medicijn toe te dienen. Gelukkig bracht de natuur ook dat in orde, toen men maar, op mijn aandringen, ophield met de eigen behandelingswijze en de zaak haar gang liet gaan.

Ik werd eens geroepen bij een vrouw, wier kind reeds bijna $2 \times 24$ uur geleden geboren was, maar de nageboorte niet. Ik zeide dat ik de zaak in een paar minuten in orde kon brengen, wanneer men goed vond, dat ik de placenta wegnam. Men vond 
dit echter zoo vreeselijk dat men mij verzocht toch maar liever medicijn te geven, al duurde het dan ook nog langer. Ik deed dit, en de zaak kwam in orde.

$\mathrm{Na}$ de geboorte van het kind wordt de navelstreng niet door gesneden, zoolang ook de nageboorte niet te voorschijn gekomen is. Al duurt dat ook dagen lang, het kind blijft bij de moeder liggen, en aangezien het dan ook niet gezoogd wordt, of verder verzorgd, hoogstens in een lapje gerold, brengt dit het leven van het kind steeds in gevaar.

Omtrent de behandeling der kraamvrouw heeft men nog al heel veel voorschriften, soms nogal van elkaar afwijkende.

$Z$ ij gaat dadelijk na de bevalling baden, volgens sommigen, moet zij zich dadelijk in zee baden, maar dat kan niet de oorspronkelijke adat zijn, aangezien men vroeger niet aan zee, maar in het binnenland woonde.

Volgens sommigen moet $z$ ij na dat eerste bad gemasseerd worden met cocosnootmelk, vermengd met o guratji: kurkuma.

Daarna moet ze zich gaan berooken, en de gewone medicijnen drinken. In de gewoonten die nu volgen maakt het geen verschil of een jongen dan wel een meisje geboren is.

Voor het berooken, dat voortgezet wordt, zoolang de logiën aanhouden, heeft men verschillende voorschriften. De eene zegt dat het gebeuren moet met het hout dat zij, de vrouw, zelf reeds van te voren verzamelde, en dat het onverschillig is, welke houtsoorten gebruikt worden, als het maar goed vuurhoudend hout is. Anderen beweren, dat men het hout na de bevalling halen moet, en slechts bepaalde soorten gebruikt mogen worden als: o ngulu, o hale, obabanga, o pohi-pohi.

Maar het is volkomen onverschillig wie het haalt, elk mag dit doen, volgens velen, hoewel toch sommigen er de voorkeur aan schijnen te geven, dat het gehaald worde door vader, moeder, of oudere zuster van de bevallene. Ook zijn er nog, die het berooken alleen doen met cocosdoppen. Uit één kampong gaf men op, dat het 't beste is, steenen gloeiend te maken en die te werpen in een bak met water, onder de vrouw geplaatst, zoodat de daardoor veroorzaakte damp benuttigd werd. Ik veronderstel echter dat dit wel een vreemde adat zal zijn, want de genezing wordt algemeen verwacht van de uitwerking van rook, en niet van die van damp.

Voor de berooking gaat de vrouw op de slaapbank liggen 
terwijl het vuur daar onder aangebracht wordt. Niet onafgebroken natuurlijk blijft ze daar liggen, maar toch meermalen daags, telkens een langen tijd.

Men mag niets van het vuur wegnemen zoolang de vrouw zich daarmede berookt, misschien omdat zulks beschouwd zou worden, als eene onderbreking van de genezende werking.

Verder moet de vrouw medicijn drinken: nanga ga u, zoo men het noemt, ook al is ze volstrekt niet ziek. Het zijn verschillende aftreksels van boombast of bladeren, die men tot dat doel gebruikt.

Wie deze medicijn haalt is ook volkomen onverschillig, wie de boomen of planten maar kent, mag het doen.

Sommigen geven azijn met een of andere wortelsoort gemengd.

Anderen gebruiken den bast van ijzerhout, en van ketapahout, ook wel van hale, eveneens nogal een harde houtsoort. Weer anderen zeggen: de basten van alle harde houtsoorten zijn goed, want het is slechts om het lichaam weer hard te maken. Het is ook wel om dezelfde reden, dat sommigen zich met hetzelfde water dat gedronken wordt, het lichaam begieten.

Een der gevraagden geeft op, dat de medicijn moet bestaan uit het aftreksel van eenige houtsoorten : o dowora, o rurumu, o balitako, gemengd met koppen van oude spijkers. Dit laatste is zoo kwaad nog niet, maar natuurlijk ook al niet oorspronkelijk. Ook zeggen anderen: men gebruikt elke houtsoortbast, die slechts bitter is, want het is te doen om de bittere, samentrekkende werking. Een zeer enkele geeft op, dat men de medicijn wel door iedereen mag laten halen, maar dat men bepaald er iets voor betalen moet, omdat ze anders krachteloos is. Nog wordt opgegeven, dat de vrouw zich, zoolang de kraamzuivering duurt, twee of driemaal daags moet masseeren met op het vuur verhitte pisangschillen.

Als voor de vrouw in deze periode verboden spijzen en dranken worden opgegeven: suikerriet, opdat niet haar kind "o kohaueri», een soort blaasaandoening krijgen zal, verder ananas of jonge cocosnoot, omdat deze het lichaam en het zog koud maken zouden; om diezelfde reden wellicht ook nog allerlei vruchten, verder ‘batatas» (o g u mini), zoete aardappelen, opdat haar kind geen gezwollen buik zou krijgen. - Dat dit een gevolg zou wezen van het eten van batatas heb ik nooit gehoord, en het verbod zal dan ook wel berusten op de ruwe Dl. 77. 
bonkerige vorm, die deze aardvruchten soms kunnen hebben. Nog wordt verboden de djamboe-vrucht (wellicht opdat het kind geen frambosia krijge). - Z Zij mag geen zoete dranken drinken, opdat haar kind niet ziek worde. - Hierbij is wel gedacht aan zoete palmwijn, die men algemeen ongezond vindt, waarom men die dan ook eerst laat verzuren, en zoo daartoe geen tijd is, door toevoeging van bittere bladen, den zoeten smaak tracht te ontnemen. Nog worden als verboden genoemd een paar vischsoorten en schelpdieren, terwijl het nog heet dat de vrouw zich, als haar kind een jongetje is, moet onthouden van het vleesch van groote dieren of visschen, opdat haar kind niet vreesachtig worde. Voor meisjes komt dit er niet op aan. Hoe men zich het verband denkt bij dit laatste verbod, is mij niet duidelijk.

Het vuile goed schijnt in den regel wel door de kraamvrouw zelf gereinigd te worden, omdat men beschaamd zou wezen, dit door een ander te laten doen.

De paar eerste dagen doet de vrouw niet veel, maar op den derden dag moet zij in staat zijn de bijl op te nemen en hout te gaan hakken.

Kan zij dit, dan is alles in orde, maar is zij daartoe niet in staat, dan is zij ziek, en moet nu door een medicijnmeester gemedicineerd worden. Natuurlijk komt er gewoonlijk een gomatere bij te pas, want er moeten booze machten aan het werk zijn, en naar de bevinding der gomateres wordt nu de vrouw gemedicineerd. Daar men zelden komt op het onnoozele denkbeeld, dat de vrouw versterkend voedsel noodig heeft, maar het zoekt in allerlei hocus pocus, kan de zaak lang sleepende blijven. Wel is het waar dat de man voor zijn bevallen vrouw visch gaat zoeken in den gewonen regel, maar men heeft nu eenmaal geen verstand van een bepaald versterkende voeding, gedurende eenigen tijd.

Het is bepaald kluchtig een man bij zoo'n gelegenheid te hooren klagen: ik heb al tweemaal visch voor haar gezocht, en nog is ze niet beter!

Omtrent het zoogen bestaan niet veel bijzondere voorschriften. De moeder mag het kind niet dadelijk na de bevalling zoogen, want haar lichaam is dan nog te onrein, zij moet eerst de medicijn gedronken hebben. Daarom ontvangt het kind het eerste voedsel dan ook gewoonlijk van een andere vrouw. Daarbij 
let men er op, dat de vrouw die het kind zoogt, een kind gebaard hebbe van dezelfde kunne, als het kind dat zij de borst geeft. Waarom is mij niet bekend.

Men let er verder op, dat het lichaam der moeder, of haar borst niet koud zij, aangezien dat ongunstige gevolgen voor het kind zou hebben. Nog zegt men dat de zoogende vrouw gedurende de eerste tien dagen geen versche visch in de hand mag houden, aangezien daardoor haar kind een vischlucht krijgen zou, en ook geen versche sagoe, opdat het kind geen last krijge van spruw in den mond.

In den gewonen regel hebben de vrouwen geen gebrek aan zog, en zij zoogen haar kinderen heel lang, tot twee of drie jaar toe. De borsten hebben allerlei vormen. Heel enkel komt het voor dat de tepels te klein zijn. Eenmaal zag ik een vrouw, wier tepels verwoest waren door framboesia. Wel werd getracht haar kinderen kunstmatig te voeden, maar zij gingen toch alle te gronde.

Soms bereikt men goede resultaten, door het kind te voeden met uitwringsel uit rijpe pisang, z. g. n. pisangmelk. Ook zag ik enkele kinderen te gronde gaan, omdat de moeder te krachteloos was en haar zog niet de noodige voedseldeelen bevatte.

Omtrent de verzorging van het pasgeboren kind, heeft men niet veel adats. De navelstreng moet afgesneden worden met een bamboemesje.

De lengte van het stukje dat aan 't lichaam blijft, is verschillend voor een jongen en een meisje. Echter, hier is een wonderlijk verschil, volgens den een voor een jongen één vingerbreedte, voor een meisje twee, volgens den ander juist andersom, voor een meisje één, voor een jongen twee.

Van afbinden van dẹn streng, hoorde ik nooit iets, maar daar het afsnijden gewoonlijk geschiedt lang na de bevalling, is dat ook niet meer van groot belang. Bovendien zeggen sommigen, dat de streng vóor het doorsnijden wat boven het vuur geroosterd moet worden. De persoon die het afsnijdt moet als belooning 10 cent ontvangen, opdat haar oogen niet duister zouden worden. Tijdens het afsnijden mag niet gesproken worden, opdat het kind geen scheeve oogen zou krijgen.

Volgens den een, moet nu het kind eerst met lauw water afgewasschen worden, anderen prefereeren koud, om dan met lauw water na te wasschen. 
Wanneer men bedenkt, hoeveel tijd verstrijkt, tusschen het geboren worden en deze eerste reiniging, dan zal het niet verwonderen dat het lichaampje ook na de reiniging nog niet schoon is, en dikwijls allerlei huiduitslagen ontstaan vooral op het hoofd, als gevolg van deze onvoldoende eerste reiniging.

Voor het wasschen gebruikt men wel allerlei bladen in het water, en bij wijze van zeep cocosolie en kurkuma.

$\mathrm{De}$ bij het wasschen gebruikte doek moet, volgens velen, weggeworpen worden.

$\mathrm{Na}$ het bad wordt het kind ingewreven met cocosolie en gemberwortel, en natuurlijk gewarmd boven het vuur (ha rauku), en dit laatste vooral blijft nog langen tijd een voorname verrichting aan het jonge wezentje, zooals vroeger de Hollandsche baker een vuurmand gebruikte. Gewoonlijk geschiedt dit zoo, dat de moeder gehurkt bij het vuur zit, met het kind op haar schoot of in den arm, een hand warmt boven het vuur, en dan met die hand het lichaampje bestrijkt of masseert.

Velen vinden het ook nuttig, dat het kind, twee of drie dagen na de geboorte, gebaad wordt in water, waarin dezelfde houtsoorten gelegd zijn, die de moeder gebruikt als medicijn (nanga gau).

Wanneer een kind geboren wordt met zonderling uitzicht, met kromme nagels, te klein of te groot hoofd, scheeve oogen, zonderlinge huidbloemen of zoo, dan zegt men dat de vrouw ook bevrucht is door een boozen geest o tokata i ma ganu: een booze geest is er mede vermengd. Het kind moet dan door den g o matere gemedicineerd worden, om den boozen invloed te verontzijdigen. Het wordt geslagen, geschopt, besproeid met allerlei waters enz., om den boozen geest uit te drijven. Blijft het kind ondanks deze kuur in het leven, dan stelt men vast, dat het kind niet zijn volle verstand heeft, i heluku: het is onwijs. Ook al vertoont het kind op lateren leeftijd volstrekt geen sporen van verstandsverbijstering, dan houdt men toch vol, dat het kind niet goed snik is.

Men vertelde mij van een vrouw, die zeven kinderen op eenmaal gebaard had. Natuurlijk was dat het werk van een boozen geest geweest, en ze waren dan ook geen van alle in leven gebleven. De vertelster haar moeder had er een van gezoogd. Het hoofd was niet grooter geweest dan een kanarienoot maar het had zoo vreeselijk gedronken, dat de vrouw haar zog opgedroogd was, daarna was het kind gestorven. 
Men stelt zich die booze geesten voor als knappe jonge mannen, en sommige jonge meisjes, die zich 's nachts al te intiem het hof laten maken, komen op die manier leelijk te pas, wat dan eerst bij de bevalling aan den dag komt. Heeft een vrouw zich eenmaal op die manier beet laten nemen, dan wordt zij haar leven lang door zoo'n geest geplaagd.

Ook worden kinderen wel z.g.n. weggegooid, b.v. wanneer ouders al veel kinderen hebben, zoodat ze meenen er niet meer te kunnen verzorgen; of wel, dat men al heel veel meisjes heeft, en nog meer meisjes krijgt; ook wel, wanneer eenige kinderen achter elkander gestorven zijn zoodat men meent dat een booze geest de vrouw volgt, om zich van haar kinderen meester te maken. In al die gevallen gooit men het kind weg, dat wil zeggen, men geeft in het bijzijn van velen te kennen, dat men om die of die redenen, het kind maar niet grootbrengen wil, en het dus wil weggooien. Daar echter over het geheel elk gaarne kinderen heeft, is er altijd wel de een of ander die zegt: o, gooi het niet weg, geef het mij liever! Daar is natuurlijk op gerekend, en het weg te gooien kind, wordt nu aan den vrager of de vraagster gegeven. De ouders verliezen er alle rechten op, alsof ze het werkelijk weggegooid hadden.

Dat men ooit kinderen in werkelijkheid weggooide heb ik nooit gehoord, zelfs twee- of drielingen niet. Ook vroeger is dat nooit voorgekomen, ten minste algemeen zeide men, daar nooit iets van gehoord te hebben. Het is trouwens ook geheel in strijd met de groote begeerte om kinderen te hebben.

Met de placenta wordt verschillend gehandeld. Men noemt die o dodomi. Wat dat woord beteekent weet ik niet; in het Ambonsche spreekt men ook van dodoming. Het woord zal dus wel niet oorspronkelijk Tobeloreesch zijn.

Weggeworpen wordt de nageboorte niet, want het kind zou dan zeker niet oud worden. Ook moet volgens de adat gehandeld worden in dezen, want is dat niet het geval, dan zou het kind niet gezond zijn. Ook zou men haast denken, dat men hiervan een boozen invloed vreest op de moeder, want volgens sommigen beklagen zich dan de ouders en broeders der moeder, en eischen een boete. Die boete kan niet geeischt worden voor slechte behandeling van het kind, of voor iets dat het leven van het kind in gevaar brengt, want het kind behoort niet bij de vrouws familie. Men moet er dus een gevaar in zien voor de moeder. 
Hoe nu de adat is, is niet gemakkelijk te zeggen. De placenta wordt gereinigd met cocosmelk. Daarna, volgens de meesten, ingebonden in de buitenschil van een cocosnoot, volgens anderen in een stuk doek.

Hij wordt nu begraven door een vreemde, volgens den een, door de moeder of de dochter, volgens den ander, door moeder, schoonzuster of grootmoeder, volgens een derde, door degene die de navelstreng doorsnijdt, volgens een vierde.

Hij moet begraven worden op de plek waar de vrouw bevallen is, volgens den een, maar anderen geven geen bepaalde plaats aan, alleen zegt éen berichtgever, dat op de plaats elken nacht licht gebrand moet worden, en nog 's avonds en 's morgens vuur. Als voor een doode dus.

Hierin komt dus de naam "o riaka", de oudere broeder, 't best tot zijn recht. Dat men, bij latere ziekte van het kind, gebruik maakt van de placenta als medicijn, is mij nooit gebleken.

Wel is dit het geval, met het afgevallen stukje navelstreng.

Dit moet zorgvuldig verzorgd, en goed bewaard worden.

Een enkele zegt: het is niets als het wegraakt, maar de meesten gelooven dat het kind daardoor ziek wordt. Ook moet het goed bewaard worden, opdat het niet aangeknabbeld worde door muizen, want daarmede zou het leven van het kind in gevaar komen.

Bij ziekte van het kind, wordt het stukje gedroogde streng in water gelegd, dat men daarna aan het kind te drinken geeft.

\section{HOOFDSTUK 15.}

\section{Van de geboorte tot het huwelijk.}

Eerst moet nu voor het kind de "o ngohaka ma nanako», "het teeken van het kind» gemaakt worden.

Voor een jongen maakt men een klein houten kapmes, een roeiriem, gereedschappen om sagoe te kloppen, soms ook een prauwtje; voor een meisje: een klein houten wiedbeiteltje, een draagmandje, een bezempje, vuurtangetjes, stokjes om sagoepap mee te roeren enz., kortom, voor elk geslacht, een nabootsing van de voorwerpen, die in het later leven noodig zullen zijn. Deze voorwerpen worden aan een soort stellage gehangen, en 
deze stellage wordt tegenover het huis, langs den weg geplaatst. Dit is dus een soort kennisgeving omtrent de geboorte. Woont men in het dorp, dan plaatst men het voor het huis, werd het kind in een tuinhuis of in het bosch geboren, dan plaatst men dit aan den uitgang van het pad, dat van het tuinhuis naar den gewonen weg loopt. Woont men langs zee, dan zet men de « $\mathrm{n}$ a nako aan het strand. Moet het kind voor het eerst langs een kaap gedragen worden, dan zet men het daar, en ook plaatsen sommigen het aan de badplaats, als men het kind voor 't eerst daar brengen wil.

Omtrent de beteekenis van dit gebruik is men het niet eens. De een zegt zus, de ander zoo. $N u$ is het wel niet meer dan een soort kennisgeving aan de menschen, maar men beweert, dat het oorspronkelijk een kennisgeving was aan de geesten van den stam, opdat dezen van de geboorte zouden weten, en het kind onder hun hoede zouden nemen.

Ook beweert men, dat het kind ziek zou worden, als men de teekens niet plaatste. Wellicht denkt men zich het kind blootgesteld aan de macht van booze geesten, waartegen het door de geesten van den stam bewaard moet worden. - Men kan deze voorwerpen zien in het Museum Prins Hendrik te Rotterdam. - Het gebruik is niet onaardig, en ook voor de Christenen niet afgeschaft, natuurlijk alleen als bekendmaking aan de levenden. Wanneer het kind voor 't eerst naar buiten gebracht mag worden, wordt ook nogal verschillend opgegeven.

Sommigen zeggen, dat tot dien tijd in huis alles rustig moet zijn, en geen vreemde mannen het huis mogen betreden. Er zijn er die beweren, dat het eerste kind pas veertig dagen na de geboorte naar buiten gebracht mag worden, terwijl het er voor de volgende kinderen niet op aan zou komen. Anderen beweren: na een maand, weder anderen: na 14 dagen, en ook zijn er die zeggen : het moet na vier dagen naar buiten gebracht worden.

In elk geval moet eerst het «teeken, klaar zijn, en daar gaat toch al licht een paar dagen mee heen.

Voor het naar buiten brengen, moet men het kind een stukje gemberwortel aan den hals hangen, om booze geesten af te weren.

Het moet dan, volgens anderen, goed met een doek bedekt worden, vooral het gelaat, opdat het niet door een $\mathrm{Sjethan}$ gezien zou worden. Bij het naar buiten brengen gebeurt het, dat vrienden en geburen het dadelijk geschenken geven, geld, 
kleeren, spijzen, en dergelijke, maar dit is niet verplicht, alleen toevallige vriendelijkheid.

Is het kind in het bosch geboren, dan moet het op den zevenden dag voor het eerst naar het dorp gedragen worden. Men moet dan wat asch meenemen, om op den weg te strooien, waar het pad versperd wordt door dikke boomen, groote boomwortels etc. opdat het kind later niet vermoeid worde.

Volgens een mededeeling uit Dodinga moet men, wanneer men een hindernis, een wortel, een groote steen, tegenkomt, op deze hindernis een klein steentje leggen, en dat bedekken met droge bladeren, of ook wel, een takje nemen, en daar het kind mee op de knieën slaan, onder het uitspreken van de woorden: blijve uwe vermoeidheid hier.

Dit alles zal wel beteekenen dat men van den lateren levensweg van het kind, de hindernissen wil wegnemen.

Volgens dezelfde bron, moet men, als het kind voor het eerst in de rivier gebaad wordt, een ring in 't water gooien.

Ook is het niet zonder gewicht, een kind voor de eerste maal op den grond te zetten. Dat moet men maar niet zonder meer doen. Het mag alleen gedaan worden door een oude van dagen, die, onder het uitspreken der woorden: ik hoop dat ge zoo oud moogt worden als ik, een rijksdaalder onder de voeten van het kind legt.

Zelf weet men niet meer wat al die formaliteiten beteekenen. Niet onwaarschijnlijk zijn een gedeelte overgenomen van andere stammen, met wie men in aanraking gekomen is.

Omtrent het speenen van het kind heeft men geen bijzondere gewoonte. Gewoonlijk beschouwd men het gespeend worden van het kind, als een teeken, dat de moeder zich opnieuw zwanger gevoelt.

Het zoogen wordt soms vreeselijk lang voortgezet.

Gewoonlijk begint men al op den zevenden dag of iets later, met het kind pisang of rijstpap te voeren. Heel aesthetisch gaat dat niet, want men propt het kind eenvoudig den mond vol met het voedsel, zoodat het onbewust voor de keuze staat: slikken of stikken, hetgeen gewoonlijk door slikken beslist wordt.

Echter, tengevolge van deze methode, gaan heel wat kinderen te gronde door maagziekten, en ik kon heel wat kleintjes redden, door de moeders aan het verstand te brengen, dat het kind aan de moedermelk genoeg had, zoolang de tanden niet te voorschijn komen. 
Voor het jonge kind is de moeder gewoonlijk heel behoedzaam. Het komt haast niet uit haar handen, met het gevolg dat het spoedig een bedorven schepseltje wordt, zóó eigenzinnig, als men dat bij Hollandsche kinderen gewoonlijk niet ziet. Het krijgt letterlijk in alles zijn zin. Men meent dat men door het kind te straffen, of wel door het te lang te doen huilen, het leven in gevaar brengt.

Ook de vader neemt gewoonlijk deel aan dit eerste deel der opvoeding. Ik herhinner me, een man die gewoon was een c vollen baard, te dragen, op zekeren dag kaalgeschoren te zien. Op mijn vraag, waarom hij zich van dat mannelijk sieraad beroofd had, klonk het antwoord: ja, u weet, mijn jongste kind wordt al zoo groot, dat het houvast in de handen heeft, en heb ik nu een baard, dan plukt ze me die zeker uit, daarom scheer ik me dien maar af.

Wel is de manier, waarop men met de kinderen speelt, niet naar onzen smaak, men houdt een jongetje b. v. b. heel kalm zoet, door met zijn geslachtsdeelen te spelen!

Als de koude of ziekte het voorloopig niet anders gebied, loopt het kind gedurende de eerste jaren zijns levens naakt.

Een bepaalde leeftijd om ze voor het eerst te kleeden, is er niet. Men wacht er mede, tot men ziet dat het kind zelf iets van schaamte begint te gevoelen. Den jongen bindt men dan eerst een touw om zijn middel, de eerste lendenband, en zachtjesaan begint men met daar een stukje lap tusschen te steken, dat de eerste schaamtebedekking is.

Een meisje geeft men eerst een stukje sarong als speelgoed: o ngòere i hiule-ule, zij speelt met den sarong zegt men, m. a. w. : haar schaamtegevoel is nog niet heelemaal ontwikkeld. Men zegt dat voornamelijk, indien de een of ander een nog niet huwelijksrijp kind ten huwelijk vraagt. Voor de rest is de leeftijd waarop zich dat schaamtegevoel begint te ontwikkelen, nogal verschillend. Ik herinner me, dat in de kampong Mawea, een volwassen, zelfs al eenigszins bejaarde vrouw was, die eigentlijk altijd naakt liep. Dat was haar adat zoo, zij hield nu eenmaal niet van het dragen van een sarong, zei men. 's Nachts maakte zij daar wel gebruik van, als zij het koud vond, maar zoodra zij het 's morgens weer warmer vond, vouwde zij de sarong weer op, en legde die op haar slaapmat, om nu voor de rest van den dag weer naakt te gaan. Niemand dacht er aan 
haar te dwingen zich te kleeden. Als zij het zelf niet noodig vond, waarom zou een ander het dan doen? Ik zag haar tusschen andere vrouwen zitten in een huis, ook in gezelschap van mannen, maar met Oostersche beleefdheid keek niemand naar haar, en ook niemand deed alsof hij in haar gedrag wat vreemds vond.

Meisjes moeten al gauw allerlei diensten verrichten in de huishouding, maar de jongens spelen.

Wat nu betreft kinderspelen, die vindt men eigenlijk niet.

De kinderen gedragen zich als kleine groote menschen. Al wat de grooten doen, doen ze na. Ze maken kleine prauwtjes van sagoebladsteel of zoo iets, en trachten daarmede te zeilen, ho ngoti-ngotiri: prauwtje spelen, of wel ze maken een soort speelgeweertjes en spelen er mee: ho hohoinapana, zij gaan elkaar te lijf met kleine lansjes van rietstelen of bamboe: ho tui-tuiëmi, en dergelijke.

Men kent een soort spel met cocosnootdoppen.

Ook wordt wel door kleinen, en ook door grooteren nog, gespeeld: ho momoloku. Men heeft daartoe een blok hout met twaalf, ook wel met acht putjes. Ook wel graaft men eenvoudig kuiltjes in den grond. Men maakt dan twee of drie rijen, clk van vier kuiltjes. Men heeft een soort knikkerachtige vruchten: o kata-kata. Daarvan legt men in elk kuilje vier. De eerst spelende, neemt nu de inhoud van het eerste kuiltje in de hand, en verdeelt dit over de volgende, in elk kuiltje één bij leggende; is de hand leeg, dan neemt hij weer den inhoud van een kuiltje, en gaat op dezelfde wijs steeds voort, tot speler op een gegeven oogenblik in een leege kuil slechts één leggen kan. Dan voligt een ander, en zoo voort. Ontmoet de speler echter een kuiltje, waar juist weer vier bij elkaar zijn, dan neemt hij die er uit, als zijn winst. Voor ons oog is het nogal geestdoodend, maar men schijnt er heel veel van te houden. Waar de naam van het spel vandaan komt, weet ik niet. Niet onwaarschijnlijk denkt men aan de Moluksche eilanden, o Moloku. Het zou ook kunnen zijn, dat het een verbasterde uitspraak is van momeleko, van elk een, waarop het spel schijnt te duiden, maar hiertegen is, dat het spel ook onder denzelfden naam bij andere stammen bekend is, die het: voor elk één, niet uitdrukken door ho momeleko.

Ook heeft men nog ha makibiti: elkaar schoppen. Twee personen plaatsen zich zoo, dat.hun beenen, d.w.z. het rechter- 
been van den een, met het linkerbeen van den ander, naast elkaar komen te staan, zoodat de kuiten tegen elkaar drukken. Een derde probeert nu door een schop of eigenlijk "slag» met zijn been, die kuiten van elkaar te verwijderen. Dit is een zeer ruw spelletje, voor grootere jongens - ook wel volwassenen waarvan dikwijls gezwollen beenen het gevolg zijn.

Het maagd worden der meisjes wordt wel niet feestelijk gevierd, maar het gaat ook niet onopgemerkt voorbij.

Volgens sommigen onderwijst de moeder haar, in wat zij weten moet omtrent het sexueele, en waarschuwt haar voor vertrouwelijken omgang met het andere geslacht.

Zij wordt nu als jonge dochter gekleed, mo moholehe: ze is maagd. Zij draagt nu bij gelegenheden bloemen in het haar, armbanden, koralen en andere versierselen om den hals, en het haar wordt mooi opgemaakt. $\mathrm{Zij}$ heeft nu twee sarongs aan (als ze tenminste niet volgens de christelijke gewoonte, een kabaja draagt) éen waarmede ze de borsten dekt. Ze moet een mes in de hand hebben, als ze wandelt, volgens sommigen. Of dit bepaald is, om belagers van haar eer af te weren, weet ik niet, maar gewoonlijk heeft een jonge vrouw een mes of mesje in de hand. $\mathrm{Zij}$ moet nu ijverig wezen en een tuin maken, opdat ze niet voor een luie deern doorga, en daardoor een " o n gek o mo ma maratana»: een wegbloempje worde. Ook moet ze tot dat doel zorgen, dat er steeds hout en water in huis is, opdat ze niet beschaamd sta tegenover mogelijke bezoekers. Ze heeft nu voortaan in huis haar eigen slaapkamertje, met een gordijn afgeschoten. Daarin moet ze goed bewaakt worden, zegt de een, want het is nu niet passend meer, dat ze op de kokiroba, de groote bank in de voorgaanderij, slape. Een ander zegt echter: ze moet niet bij, of dicht bij haar ouders slapen, opdat een jongeling, die haar 's nachts bezoeken wil, niet afgeschrikt worde.

Het is hierbij natuurlijk al heel verschillend op welk zedelijk standpunt de berichtgever staat. Volgens oud-Heidensche manier, is men op dit punt volstrekt niet streng. Natuurlijk mag. een meisje niet tot een bepaalde lichtekooi worden, maar dat zij 's nachts bezoeken ontvangt van jongens, geldt volstrekt niet als oneerbaar.

Door haar in haar huis te bezoeken, waar hij licht betrapt kan worden door haar ouders of broers, geeft de jongen min of meer zijn ernstige voornemens te kennen. 
Maar toch behoeft uit een nachtelijk bezoek nog volstrekt geen huwelijk te volgen! Platweg gezegd, probeert men maar of men in elkaars smaak valt, en is dit, na een of meer bezoeken niet het geval, $\mathrm{nu}$, dan staakt men die eenvoudig. Het meisje is nog «o berera ma moloka, de schoondochter der heele kampong, tot daaraan een eind komt, doordien bekend wordt, dat zij iemands bruid is. Ontvangt ze daarna nog bezoeken van anderen, dan gelden die als adat-overtredingen, en worden beboet, of op andere wijze bestraft.

Men kan dus gerust zeggen, dat het met de zedelijkheid vòor het huwelijk, of vòor het verloofd zijn, niet al te best gesteld is.

Van de jongens, tot aan den huwbaren leeftijd, is juist niet veel te zeggen. $\mathrm{Zij}$ helpen wel hun vader bij verschillende werkzaamheden, maar, hebben ze zoo ongeveer den jongelingsleeftijd bereikt, dan worden ze onuitstaanbaar vervelend. De familie is bijzonder trotsch op hen, ergo worden ze èn door moeder, èn door zusters, zelfs door grootouders, vreeselijk verwend. Zij godu üru, zij jongelingen, zegt men, d. w. z. zij slenteren mooi aangekleed rond, loopen alle feesten, en vooral alle nachtelijke partijtjes af, hebben veel praats, en doen weinig.

Hoe eerder ze tot een huwelijk komen, hoe beter het voor hen is.

Helaas, velen stellen het huwelijk zoo lang mogelijk uit, leven loszinnig, en bederven het lichaam dikwijls, nog vóor zij tot een huwelijk komen. Ook schijnt, te oordeelen naar uitdrukkingen die men hoort, tegennatuurlijke ontucht, onder hen niet zeldzaam te zijn. Ik hoorde meermalen zeggen, omtrent jongelui die kort na het huwelijk er vreeslijk slecht uit gingen zien: a i hawā wi daene: hij wordt getroffen door zijn (vroeger gepleegde) tegennatuurlijke ontucht.

Dikwerf doen ouders, die dit gedrag met leedwezen zien, alle mogelijke pogingen, om hen maar tot een huwelijk te brengen, want daarna is het, voor de niet bepaald slechten ten minste, met de loszinnigheid gedaan.

Men kent ook het tanden vijlen, hoewel niet zoo wreed als bij vele andere stammen.

Beide geslachten laten zich de tanden vijlen, hoewel het niet algemeen is. Men ziet ook wel personen, wier tanden niet gevijld zijn geworden. Men wacht tot de persoon ongeveer volwassen is, in elk geval, tot de tanden uitgegroeid zijn, en vijlt ze nu gelijk.

$\mathrm{Na}$ het vijlen laten sommigen ze met verschillende sappen zwart maken maar anderen ook niet. 
Velen verzekerden $\mathrm{mij}$, dat $\mathrm{zij}$ het voor het eten en kauwen gemakkelijker vonden, dat de tanden niet meer ongelijk waren. Men kon nu beter bijten. In elk geval worden de tanden niet sterk ontsierd of zwaar beschadigd. Ofschoon men dat, vooral voor het mannelijk geslacht, nogal sterk ontkend, schijnt het toch wel met de puberteit saam te hangen.

$\mathrm{Al}$ is het niet verplichtend, dadelijk na het intreden der puberteit, toch worden geen personen eraan onderworpen, die nog niet geslachtsrijp zijn. Ziet men een meisje met gevijlde tanden, dan weet men zeker dat zij maagd is. Evenwel gebeurt het ook op verderen leeftijd, bij een vrouw na haar huwelijk b. v. b., maar het mag dan alleen door de mans broeder gedaan worden.

In sommige dorpen schijnt het bepaald als een bewijs van verloofdzijn der meisjes te gelden, en volgens sommigen mocht het bij een man vroeger niet gebeuren, zoolang deze nog geen deel genomen had aan zeerooftochten.

Omtrent de oorzaak of het waarom weet men niets, ook zijn mij daaromtrent geen verhalen bekend, zooals b.v. b. de Toradja's die hebben.

Het vijlen heet: ha roko. Men gebruikt een platte zwarte steen als gereedschap, o roroko, ook o momori of o djoma geheeten, of, als hohono (vervangwoord) o gota ma gogoli: de afbijter van het hout.

Het moet met nieuwe maan gebeuren, zegt men, opdat de pas gevijlde tanden blinken zouden als de maan in haar opgang. Ik denk echter dat hierbij wel gedacht is aan de sympathische werking van de wassende maan, om bederf der tanden tegen te gaan.

Het moet gebeuren 's morgens vroeg, als er nog geen wind is, opdat door de wind geen pijn in de tanden ontsta.

Gewoonlijk gebruikt men een steen, die meermalen reeds voor dit doel gebruikt werd. Een bepaald persoon is er niet voor aangewezen, maar het is natuurlijk, dat iemand die reeds eenige handigheid in 't vak heeft, nogal toeloop krijgt.

Men kan de betaling voldoen met een maaltijd, en dat gebeurt nogal veel, maar dan geldt die maaltijd ook beslist als betaling, want zonder betaling mag het niet. De tanden zouden dan niet duurzaam zijn.

De betaling is, volgens den één voor een meisje 25 cent en 
voor een jongen 10 cent met nog $3 \frac{1}{2}$ cent palmwijn, en een schotel rijstkoek; volgens anderen voor een ongetrouwde 25 cent maar voor een getrouwde vrouw $f 2.50$. Tijdens het vijlen mogen geen makkers tegenwoordig zijn, misschien om later niet bespot te worden over de houding die men aangenomen heeft, want een aangename operatie is het niet.

De operateur brengt zijn gereedschappen, benevens nog eenige kruiden die als medicijn moeten dienen, op een schotel mede, en op die schotel wordt ook de belooning gelegd.

Volgens sommigen mag een man zich niet de bewerking doen ondergaan zonder voor zijn afgestorvenen geofferd te hebben (o gomanga ho hakai). Wellicht omdat dat dan op volwassen leeftijd gebeurde, en men er een afneming van kracht in zag, waartegen men zich van te voren, door de afgestorvenen te vriend te houden, te weer stelde.

\section{HOOFDSTUK 16.}

\section{Verloving en huwelijk.}

Een bepaalde vorm van huwelijk kennen de Tobeloreezen niet. Wel heeft men allerlei plechtigheden en feestelijkheden en gewoonten, maar het is zeer moeielijk om te zeggen, in welke van die alle nu het essentieele deel van het huwelijk bestaat. Feitelijk moet men zeggen: in het openlijk in huwelijksgemeenschap met elkaar leven, want doen twee lieden dat, dan gelden ze voor getrouwd, ook al heeft er geen ceremonie plaats gehad. Vooral bij lieden op meergevorderden leeftijd heeft zulk een huwelijk meermalen plaats. Een vrouw woont hier of daar in een tuin in haar tuinhuis, en plotseling hoort men, dat ze haar slaapplaats met iemand deelt. Men zegt dan eenvoudig: ze zijn getrouwd, en daarmede is alles uit; al komt nu ook zoo meteen nog de familie der vrouw om een bruidschat vragen, doet dat het huwelijk niet te niet, ook niet als die vraag soms bits afgewezen wordt.

Gaat alles echter met jongelui langs den geordenden weg, dan gaat het zoo: het is mogelijk dat de jongeling zelf het meisje zijner keuze uitzoekt en begint 's nachts sluipertjes bij haar te maken. Maar hij wordt dan misschien betrapt, of laat 
zich betrappen. In 't laatste geval blijft hij maar meteen in huis, vooral als hij een vreemdeling in de plaats is.

Echter, gewoonte is, dat de jongen kennis geeft van zijn verliefdheid aan zijn ouders. $\mathrm{Nu}$ is het nog lang niet zeker, dat de ouders daarmede accoord gaan, want, vooral de moeder, stelt wel eenige andere eischen dan haar zoon. Is deze laatste gesteld op een mooi figuurtje, en een mooi gezichtje, (de meisjes zijn dikwerf heel bekoorlijk, en men prefereert de slanken boven de meer gezetten), de moeder wil vooral, dat het haar lieve zoon aan niets ontbreke wat de voeding betreft, en daartoe moet hij een werkzame vrouw hebben. En mooi en werkzaam gaan wel eens niet samen. Meisjes die zich mooi weten, zijn nogal dikwerf aan den luien kant. Echter heb ik ook een geval gekend, waarbij de schoonmoeder wel veel meer verliefd scheen op het mooie figuurtje der schoondochter dan haar zoon, en jaren lang zelfs niet toestond dat ze eenig werk verrichtte, opdat haar figuur niet bederven zou, of ze harde handen zou krijgen van het werken. Zulke schoonmoeders zijn echter heel zeldzaam! Ook is de ouders de familie lang niet onverschillig, waarin hun zoon introuwt, en waarmede zij dus verbonden raken.

Vooral voor menschen die als inhalig bekend staan, is men nogal op zijn hoede, omdat de trouwceremonieën, en ook later het huwelijk, zooveel gelegenheden aanbieden, die inhaligheid bot te vieren.

Ook heeft men niet gaarne een schoonvader met een al te grooten mond, want dan hebben de schoonzoons het niet te best, aangezien dan later bij elke huwelijkstwist, de vrouw wegloopt naar haar vader toe, die het door brutaliteit doorzet, dat de man steeds weer moet betalen.

Op al deze dingen letten de ouders, als de jongen daartoe in zijn verliefdheid te dom is. Het is dus zeer goed mogelijk, dat de ouders heel andere plannen hebben, en trachten die door te zetten, door een ander meisje voor hun zoon te gaan vragen, in welk geval de zoon gewoonlijk te beschaamd is, om zich tegen den wil zijner ouders te verzetten. Is hij dat niet, dan loopt hij met het meisje zijner keuze weg, en zet zijn ouders voor een fait accompli, waarover straks nog.

$\mathrm{Nu}$ kan het zijn, dat het meisje nog te jong is voor een huwelijk, of dat de jongen nog op reis gaan wil voor het huwelijk gesloten wordt. 
De jongen heeft dan wel poolshoogte genomen, door het meisje het een of ander te schenken als "tapu» anker. Heeft zij dit aangenomen, dan wil zij hem wel, en nu kunnen wel zijn ouders gaan om haar te "gahoko», om haar vragen. Volgt eerst nog een verlovingstijd, dan heeft het uitwisselen van liefdesteekenen plaats. De ouders geven al vast iets als geschenk aan het meisje, ook wat aan haar familie: i mi tapu, zij verankeren haar.

Gaat de jongen op reis, dan verwisselen zij wel onderling van sarong, ook geeft het meisje den jongen wel een bosje van haar hoofdhaar.

Wordt de jongen nu het meisje ontrouw, dan is hij zijn geschenken kwijt, maar wordt het meisje ontrouw, dan moet zij niet alleen het geschonkene teruggeven, maar kan ook nog wel beboet worden bovendien, omdat de familie van den jongen man anders beschaamd is.

Het aanstaande huwelijk kan ook ingeleid worden, doordien de jongeman naar zijn bruid een tros fraai besneden pinangnoten brengt: o rò ha, en haar daarmede zijn liefde verklaart: wo mi roha. Dit gebeurt dan des avonds. Wordt hem 's morgens de heele tros pinangnoten teruggebracht, dan heeft hij niets te hopen. Maar heeft de jonge dochter er van gepruimd, en zendt zij hem bovendien nog een bordje met de een of andere spijs, dan is zijn aanzoek welgevallig.

Gaan de ouders officieel vragen, dan neemt men gewoonlijk een sirihdoos mee, bedekt met een doek. 'Die wordt aan het meisje overhandigd. Bedient zij zich van de sirih, alvorens de doos terug te geven, dan behoeft er verder niets gezegd te worden, men keert verheugd terug, want het aanzoek is aangenomen. Natuurlijk is er nu al wat feestelijkheid, zooals er ook al een min of meer plechtige bijeenkomst geweest is van de familie, eer men tot het aanzoek overging, want zoo iets wil in de heele familie bepraat worden.

Men kan nu overgaan tot het: ho ma dunia, het vaststellen der huwelijksvoorwaarden. Men kiest van de manskant daartoe iemand uit die gladtongig is, en heeft men zoo iemand niet in de familie, dan wordt er wel iemand gezocht onder de vrienden of verre verwanten. Natuurlijk wordt de komst van te voren officieus aangekondigd, zoodat degene die komen, de heele familie verzameld vinden. Nu begint er een soort gesjacher over den bruidschat, waarbij allerlei onedele hartstochten in het 
spel komen. Men weet wel ongeveer hoeveel zal geëischt worden, want een soort adat bestaat op dat punt wel, ook al is die nog heel verscheiden in verschillende kampongs en dorpen.

Bij de Kausche Tobelo's werd veel meer betaald, dan bij de Tobeloreezen van Tobelo zelf; bij de Dodingaërs niet zooveel maar over het geheel bestond de zucht, den bruidschat op te drijven.

Oorspronkelijk was die $f 70 .-$ maar voor een 20 jaar werd in het Kausche wel $f$ 300.- betaald, en ook in het Tobelosche kwam het wel tot $f 250$.- . Men rekende daarbij met huwelijksrealen à $f 2$. - . De huwelijksreaal had 5 su kus à $f 0.40=f 2$.dus, maar de gewone reaal, voor het betalen van boeten, slechts 4 sukus à $f 0.40$ dus $f 1.60$. Deze reaal is natuurlijk een denkbeeldige munt. Wel heeft men nog sommige oude zilverstukken, "o likitong" geheeten, die voor een reaal gelden, maar daarmede betaalt men toch geen bruidschat, of 't moest zijn in den uitersten nood. Want die behooren tot de familieschatten, en bij het dunia worden die door de jonge dochters, zusters of nichten van den aanstaanden man, om den hals gedragen, om de grootheid en rijkdom der familie te bewijzen, waarin het jonge meisje huwen zal.

Heel veel worden zulke stukken ook uitgeleend voor dit doel, maar men bedient zich voor dat doel ook wel van rijksdaalders en ook hiervan wel geleende, (ik heb ze meermalen zelf voor dit doel uitgeleend).

Bij het bepalen der som wordt nu gerekend met realen, en bij de betaling, als men met oude stukken betaalt, telt een rijksdaalder voor een reaal van $f 2$. -, en met ander soort stukken dan rijksdaalders of likit ongs betaalt men niet, tenzij dat men bepaald heeft dat een gedeelte reaal piring zal zijn, of reaal ngoěre, d.w.z. dat men betalen zal met borden, die dan ook elk voor één reaal gelden, evenzoo stukken grof wit katoen, madapollam, per stuk een reaal. In lateren tijd kwam dit echter niet veel meer voor. Waar men, door meer "tokos», gemakkelijker goederen kon koopen, nam men liever geld aan. Vroeger wạs het verkrijgen van borden voor feestelijke gelegenheden wel eens moeilijk, en vandaar wellicht, dat men toen liever borden had dan rijksdaalders.

Echter, bij de bruidschat kan nog meer komen, dan alleen de vastgestelde som. Ten eerste: o a hali ma doa, het afhakken Dl. 77 . 
van de bloedverwantschap. Wel zijn er bepaalde graden, waarin men mag of niet mag trouwen, maar ook daarin laat zich heel veel sjacheren.

Het huwelijk komt voor tusschen volle neven en -nichten, hoewel velen dat niet gewenscht achten, maar: vrijheid, blijheid! Wiens hart zich niet tegen zulk een nauwe verwantschap verzet, kan wel aldus trouwen, als hij maar betaalt.

Maar ook bij verdere verwantschap, achterneven en nichten, moet er volgens den adat nog betaald worden, en desgewenscht wordt dat nog veel verder getrokken, zoodat bij een betrekkelijk niet heel groot volk, gemakkelijk een soort verwantschap aan te toonen is, om welke af te snijden dan "o ahali ma doa" geeischt kan worden. Ook zelfs tusschen twee verschillende $\mathrm{h}$ oan as komt het nog gemakkelijk voor.

Men huwt namelijk zoowel in als buiten de hoana, zonder eenige beperking.

$\mathrm{Nu}$ is de afkoopsom voor het afsnijden van den band des bloeds, niet altijd even groot. Hoe dichterbij de verwantschap, hoe grooter de afkoopsom, van tien tot zelfs twintig realen.

En ook heel dikwijls moet er "o koboto ma hohoko»: "de vrucht van den eed", betaald worden. Dat komt, omdat de vader omtrent zijn dochter gezworen heeft, om de een of andere reden, dat ze niet zal trouwen, ò wel dat ze niet met dien jongen zal trouwen, òf wel dat ze niet in die familie zal trouwen. Daartoe kan allerlei aanleiding geweest zijn. En natuurlijk, als men nu toch gezworen heeft, kan men daar niet over heen komen, tenzij dat er een zilveren brug gebouwd worde, om over dezen afgrond heen te trekken.

Sommige vaders zijn zoo loslippig op dit punt, dat hun dochters wel altijd onder den een of anderen eed staan. Dus moet ook dat met vijf tot tien realen betaald worden, naar ' $t$ meer of minder gewicht van den eed.

En nu nog, als de families niet al te ver van elkaar afgewoond hebben bijna altijd "o maleke ma dadatoko", bedekking der schande.

Bijna altijd heeft het jonge mensch zich wel eens lomp of oneerbiedig gedragen tegen een der aanstaande familieleden. In den regel zijn dit volstrekt geen groote gevallen, het is slechts de een of andere oneerbiedigheid of kinderachtigheid, waaraan men wel niet zou gedacht hebben, als door het aanstaande 
huwelijk de kans niet ontstond, hier wat uit te kloppen. Was het bepaaldelijk een adat-overtreding geweest, die beboetbaar was, dan had men het wel dadelijk aan de Hoofden geklaagd, of zich er, ook zonder de hulp der Hoofden, voor laten betalen. Maar nog eens, de gelegenheid is nu gunstig, en wanneer dit nu niet betaald wordt, ziet de een of ander der a.s. schoonfamilie wel geen kans, met het jonge mensch in nauwere betrekking te komen. Er moet dus "o maleka ma dadatoko» betaald worden.

$\mathrm{Nu}$ is dat natuurlijk wel geen deel der bruidschat, maar het komt toch gewoonlijk bij het ho ma dunia ter sprake, hoewel het ook gebeurt, dat de een of ander, die bij het dunia niet tegenwoordig was, na een paar dagen met zijn eisch op de proppen komt. Ook moet dit geld nog vóór het huwelijk betaald worden.

Gewoonlijk gaat het zoo, dat de beleedigde partij informeert, wanneer men wil komen betalen. Hij zorgt dan ook zijn familie wel bij elkaar te hebben, en richt een feestje aan, door de noodige rijst te koken en de noodige palmwijn klaar te hebben, om de boetvaardigen te onthalen. Heel veel voordeel heeft hij er dus wel niet van, want het loopt uit op een vroolijk verzoeningsmaal, maar natuurlijk, dan toch in laatste instantie op kosten van hem die beleedigd heeft, ergo den bruidegom.

Ik herinner me een geval, waarin ook iemand een bruidegom op die manier beboet had, en ook zelf een dag had bepaald, waarop de boete gebracht moest worden. De bruidegom had wel niet rechtstreeks toegezegd, maar ook niet geweigerd, dus was er op gerekend, dat hij komen zou om te betalen. Maar helaas, een brutale oom stookte den bruidegom op niet te gaan, omdat hij daartoe volstrekt niet verplicht was. De man die de boete eischte, richtte echter een feest aan, en was natuurlijk nu eerst recht beleedigd, nu hij zat te wachten op zijn vermeende beleediger, en deze niet verscheen.

Het werd nu een groote zaak, want de man eischte nu ook nog betaling voor de schade hem hierdoor overkomen. Hoe de uitspraak der Hoofden was, weet ik niet, maar door zooiets ontstaat natuurlijk een wrok, die dikwijls nooit weer verdwijnt.

$\mathrm{Nu}$ is het mogelijk, dat ook nog betaald moet worden: o borakata ma doaka; het verbreken van de rouwgelofte.

Het gebeurt n.l. dat een vader, bij een sterfgeval in de familie zóó bedroefd is, dat hij op zijn dochter de verplichting legt, 
nooit te trouwen, ook wel: gedurende een aantal jaren niet te trouwen en ook dit kan natuurlijk alleen door afkoop van de zijde des bruidegoms verbroken worden.

$\mathrm{Al}$ deze dingen zouden ongeluk aanbrengen indien zij niet betaald werden.

Het is bij de Tobeloreezen merkwaardig, dat alle overijlde beloften of roekelooze eeden, voordeel afwerpen voor hem die ze doet of zweert. En zoo kan in dit geval ook een bedroefde vader of moeder, misschien ook broeder, alleen over de droefheid heenkomen met een geschenk.

Zoo ziet men dus, dat er op deze wijs nog allerlei bij de eigenlijke bruidschat komen kan. Dit is n.l. allemaal nog geld dat door de familie van den aanstaanden man betaald moet worden.

Is het dunia goed gegaan, is men het eens geworden, dan kan de plechtige intocht van de bruid volgen. Maar in den tijd dien nu, tusschen het officieel vaststellen van het huwelijk en het huwelijk zelf verloopt, kan men nog wel weer wat van de aanstaande mans-familie halen.

De familie van het meisje gaat n.l. ho ma roka d.w. z. elke vrouw voorziet zich van een schotel of bord, met de een of andere spijs, en men gaat nu in optocht naar het huis van den vader of van de naaste familie van den aanstaanden echtgenoot. Daar is men wel gewaarschuwd, en elk der familieleden ontvangt nu een bord met spijze ten geschenke. Dat wordt aangenomen, natuurlijk wordt een bamboe palmwijn leeggeschonken aan de bezoekers, en nadat de borden geledigd zijn, worden die teruggegeven, maar in elk is nu een geldgeschenk gelegd, misschien maar $f 0,25$, maar ook misschien wel $f 1$. - of meer, en in elk geval overtreft de waarde van het geldgeschenk, verre de waarde van de geschonken spijs. De hoegrootheid van dit tegengeschenk hangt wel zoowat af van de houding die men wil aannemen, of men zich als rijk en voornaam voor wil doen of niet. Het laatste is nogal gevaarlijk, want dat prikkelt maar de familie om de aardigheid nog eens te herhalen.

Ik hoorde eens een inhalige oude vrouw zeggen bij zoo'n gelegenheid : mijn handen jeuken nu eenmaal door het ontvangen.

En de familie van den a.s. echtgenoot, moet nog een goed gezicht zetten bij dit alles, want het wordt immers alleen uit pure genegenheid voor de aanstaande familie gedaan! Geschenken stevigen toch de vriendschap! 
Het eenige wat tegen deze vriendschappelijke afzetterijen te doen is, is het huwelijk zooveel mogelijk te bespoedigen.

Zoolang nu niet alles in orde is, mag het jonge mensch niet de woning van zijn aanstaande vrouw bezoeken. Hij doet het echter toch wel, maar natuurlijk stilletjes, des nachts. Wordt hij betrapt, dan wordt hij beboet.

Vooral moet hij nu oppassen niet in de nabijheid van de slaapplaats zijner aanstaande schoonouders te komen, want dat is sterk verboden terrein. Slaapt dus het meisje dicht bij haar ouders, dan is dit wel zoowat een teeken, dat hij beter doet met voorloopig maar weg te blijven.

Gewoonlijk maakt zijn liefste voor hem een mooi sirihdoosje, of vooral een mooie hoed, werkelijk prachtig versierd met opgenaaide koralen.

Ook geeft hij nog wel geschenken aan zijn aanstaande.

Voor hij voor 't eerst officieel zijn aanstaande schoonfamilie bezoekt, of de schoondochter officieel bij haar schoonouders komt, moet nog een moeilijke les geleerd worden, n.l. de namen der schoonouders en zwagers te vervangen door andere woorden, ho hohono. Men spreekt elkaar, ook zelfs bij het eerste bezoek, niet meer aan dan met den naam, die voortaan de familieverhouding uitdrukt, als schoonvader, schoonmoeder, zwager, schoonzuster. Dat is dus niet zoo moeilijk, maar het moeilijkste is, om 'alle woorden, die of geheel overeenkomstig zijn met die van een dier familieleden, die men voortaan met dien verwantschapstitel zal aanspreken, te vervangen door andere, want die woorden worden nu voor dien persoon verboden. Hij mag de namen niet meer uitspreken, maar aangezien de namen bijna allen uit het dagelijks leven genomen zijn, verdwijnen nu meteen een heele boel woorden uit de dagelijksche woordenschat, die door anderen vervangen moeten worden.

Gesteld (om de zaak in het Hollandsch begrijpelijk te maken) dat iemand b.v. een schoonvader kijgt die "boerenkool, heet, dan mag hij voortaan het woord "boerenkool» natuurlijk niet meer uitspreken, en moet daar wat anders voor zoeken; de groene groente b.v. Maar even goed zou hij andere woorden moeten zoeken voor al de woorden, waarin of het woord "boer» of het woord "kool» voorkomt, en men vrage zich af, hoeveel woorden dat wel kunnen zijn. Nu geldt dit alleen voor de namen van schoonvader en -moeder, en voor vrouws 
broers en zusters, maar daar men hier ook ooms en tantes als vader en moeder noemt, neven en nichten ook broer en zuster, ga men na hoe ver deze beleefdheid, want dat is het, wel gaan kan, en welk een moeilijk stuk werk verricht moet worden eer men bij de nieuwe familie met nieuwe woorden spreken kan.

Van de meest voorkomende woorden zijn de vervangwoorden, de 'hohono's, algemeen bekend. Het gebeurt echter, dat in de namen der nieuwe familie zoowel een zeker woord, als ook het bekende vervangwoord daarvoor, beiden voorkomen, en dan moet men halsbrekende toeren uithalen, om nog weer een ander vervangwoord te vinden.

Voor oningewijden zijn die woorden ook dikwerf zoo goed als volkomen onverstaanbaar, hoewel natuurlijk elk met deze gewoonte rekent bij het beoordeelen van iemands uitdrukkingen, en niemand zoo onbeleefd is om te zeggen: wat praat jij gek, als de een of ander zich onbeholpen uitdrukt.

Men kan in dezen wel zeggen: gelukkig wie weinig schoonfamilie heeft.

Als scherts vertelt men elkaar verhalen van iemand die twaalf zwagers en evenzooveel schoonzusters had, en de taal zoo radbraakte, dat bijna niemand hem meer verstond. Het is een soort beleefdheid, en wordt men door den persoon wien het geldt, betrapt op misbruik van diens naam, dan moet men zich met een of ander, een mes, een doekje of zoo iets verontschuldigen. Wordt geweigerd deze verontschuldiging te geven, dan ontstaat er een kloppartij, want men gevoelt zich toch min of meer beleedigd.

Voor een vreemdeling heeft deze gewoonte nog al wat onaangenaams, want vraagt men iemand naar den naam van een ander, en degene naar wien men vraagt is een lid der schoonfamilie, dan klinkt het antwoord: ik weet het niet. Moet men beslist het woord noemen, dan zegt men vervolgens heel snel achter elkaar: tabea! tabea! en spuwt op den grond, om als 't ware den mond te zuiveren van de onbeleefdheid. Gewoonlijk echter wordt, zoo men blijft aandringen, eindelijk het woord genoemd, 't welk men gewoon is als vervangwoord te gebruiken. Vraagt men later anderen naar iemand aldus geheeten, dan beweert men: die is er niet of bestaat niet. Onder elkaar levert ook dat minder bezwaar, want in deze maatschappij weet wel zoowat iedereen wie iedereens schoonvader is, en schoonbroers kan men gewoonlijk 
benoemen naar hun oudste kind, als: de vader van die of die. Dat weet ook elk wel, behalve natuurlijk de vreemdeling, b.v. de ambtenaar die in het dorp komt om de belastingplichtigen op te schrijven, en soms wanhopig wordt, omdat het hem maar niet gelukt de juiste namen uit te vinden.

Op Christelijke of Mohammedaansche namen, wordt dit alles niet toegepast. Dat deze manier van doen, wijzigingen in de taal moet brengen, is wel duidelijk. Een kind neemt al de vervangwoorden van zijn ouders gemakkelijk over. Wel weet hij later dat het hohono's zijn, maar hij is nu eenmaal gewend de dingen aldus te noemen, en blijft er bij. Het is daarom voor een vreemdeling die de taal leert, soms heel moeilijk te weten wat de juiste woorden zijn, en toch lacht men hem een beetje uit over het gebruik van hohono's, omdat hij wel geen schoonfamilie heeft onder het volk, en dus van de rechte woorden, naar believen gebruik mag maken.

Vanwaar de gewoonte, die men even goed bij andere volken vindt, zijn oorsprong heeft, is moeilijk te zeggen. Het is vereering van de schoonfamilie. Over het geheel bewijst men daar nogal eer aan, vooral ook, aan de schoondochter, de moloka. Ten opzichte van haar is men al heel prikkelbaar. O $\mathrm{njawa}$ manga moloka: iemands schoondochter, is een tamelijk onschendbaar persoontje, zelfs haar eigen broeders of ouders, mogen haar niets doen of bevelen, dat mag alleen haar man of haar schoonfamilie, want ze is hun schoondochter, dat is al een van de nauwste banden, die men kent.

$\mathrm{Nu}$ is het mogelijk, dat hierbij alleen aan het bezitrecht gedacht moet worden, als gevolg van het betalen der bruidschat, want men zou zich vergissen wanneer men meende dat zij ook door de schoonfamilie zelf of door haar man steeds met eerbied behandeld werd. Dat is volstrekt het geval niet. Het is alleen, dat de buitenwereld haar beslist beschouwen moet, als behoorende tot haar schoonfamilie, en dat beleedigingen haar aangedaan door iemand buiten de familie staande, beschouwd worde als de eer harer schoonfamilie aan te randen.

Om nu te komen tot de officieele sluiting van het huwelijk, moet de bruidschat gebracht worden, naar het huis van de ouders der bruid.

De bruidschat heet: o huba: 't geen men aanbiedt, ook: o kawing ma idja: de huwelijksprijs, ook wel; o kawing 
ma dola: de inhoud van het huwelijk. Het geld wordt gewoonlijk op een bord gedragen, bedekt met een doek, en men brengt tevens verschillende voorwerpen, die soms nog bij den bruidschat behooren als: een lans, een bord, etc.

$\mathrm{Nu}$ is het bij sommigen wel de gewoonte, dat de bruidegom reeds tevoren een officieel bezoek brengt, en dan spijzen meebrengt, waarvan de schoonfamilie eet, opdat de nieuwe schoonzoon later niet beschaamd zou zijn, om met zijn schoonfamilie te eten. Bij sommigen laat hij dan, na het eerste bezoek achter de deur, een kapmes of lans staan, als geschenk voor zijn aanstaande schoonvader. Natuurlijk wordt ter gelegenheid van het brengen van den bruidschat een feest gevierd, grooter of kleiner, langer of korter, al naar de omstandigheden dit toelaten.

$\mathrm{Bij}$ de Dodingasche Tobeloreezen, loopt de a.s. echtgenoot, als hij voor de eerste maal op weg gaat naar het huis zijner a.s. vrouw, met gebogen hoofd, en uitgestoken handen, en wordt geleid door een oud familielid. Aan het huis gekomen valt dan de jonge man dadelijk op den grond, en blijft daar liggen, terwijl de rest van het gezelschap zich op banken zet. Een familielid van den a.s. echtgenoot presenteert dan pinang, waarna een oud familielid van de a.s. vrouw het jonge mensch allerlei vermaningen geeft, omtrent hoe hij zich te gedragen heeft tegenover zijn schoonfamilie, tegenover zijn vrouw, kortom, over zijn plichten als echtgenoot en als schoonzoon. Daarna pas staat de man op, en zet zich op de bank neer.

Terwijl dat plaats heeft in de voorgaanderij, wordt binnen in het huis het meisje gekleed, en een lid der mansfamilie gaat naar binnen, legt de hand op haar, en bekleed haar met kleederen, die de mansfamilie voor haar medegebracht heeft. Daarna wordt zij naar buiten gebracht bij haar man, waarna dezelfde oude heer, die haar man vermaand heeft, ook haar onderhoudt, omtrent haar aanstaande plichten als echtgenoote en als schoondochter.

Of dit ook zóó bij de Kausche Tobelo's plaats heeft, weet ik niet, maar bij de Tobeloreezen zelf heb ik nooit van iets dergelijks gehoord.

Wel deelde men mij mede, dat bij sommige Kausche Tobelos de gewoonte is dat het jonge mensch bij het eerste bezoek op den grond gaat zitten, tot de praeliminairen afgeloopen zijn, en dat daarna pas zijn schoonfamilie hem op de bank beurt, en hem pinang presenteert. 
Van een ander dorp vertelde men, dat de man bij zijn eerste komst, al zijn schoonfamilie pinang moet presenteeren, en daarna stil moet neerzitten. Is er het een of ander te doen, dan zet men hem daar maar aan. Het is dus wel plaatselijk verschillend, wat men als adat in deze te beschouwen heeft.

Men maakt nu feest, en dit feest is wel het eigenlijke trouwfeest. Het gaat er vroolijk toe; er wordt gedanst, gezongen, gegeten en gedronken, zooveel men maar kan.

Voor den bruidegom kan dit feest nogal duur uitloopen, door allerlei spelletjes of wat men maar aldus gelieft te noemen. Ten eerste kan hij door zijn schoonfamilie voor allerlei verplicht worden: ho dung on o. Zijn zwagers, ook wel vooral de broeders van zijn schoonvader zeggen tegen hem: ik dung on o je voor dit of dat, voor een prauw, een geweer, een werpnet, of zooiets. $\mathrm{Hij}$ is nu verplicht het aldus van hem geeischte te geven, ten minste hij mag vooral niet toonen dat hij het niet geven wil, want dat zou als onbeleefdheid aangemerkt worden. Dit is niet iets waar zijn familie, maar waar hij persoonlijk voor moet opkomen. Natutrlijk is dat niet gerechtelijk invorderbaar, maar toch rust de eischer in den regel niet, tot hij gekregen heeft wat hij begeerde. Het beste middel tegenover een onwillige in deze is beschaamd maken, als men gezamenlijk een feest bijwoont, want de Tobelorees is heel gevoelig voor beschaamd gemaakt te worden. Er zijn mij gevallen bekend, dat reeds bejaarde menschen op een feest zoodanig geplaagd werden, dat zij plotseling opstonden om het gewenschte voorwerp te halen, een geweer, een schild of zoo iets, om op die manier van de plagerij af te komen.

Wat anders is het weer, dat de kameraadjes van de bruid, den bruidegom allerlei kleine voorwerpen overhandigen, stokjes, steentjes of zoo iets, met bijvoeging: dat is mijn mes, haarspeld, zakdoek, of dergelijke kleinigheid. Gewoonlijk worden geen groote of kostbare voorwerpen genoemd. De bruidegom moet nu dit alles met een ernstig gezicht in bewaring nemen, en, alsof hem werkelijk de genoemde voorwerpen geleend waren, die terug geven.

Een andere methode is weer, dat de meisjes uit de vrouwsfamilie, allerlei gebakjes van rijstmeel hebben klaargemaakt, en die nu aan de jongelui van de mansfamilie op het feest presenteeren. Natuurlijk moeten die aangenomen worden, maar er moet ook voor worden betaald, ver boven de waarde, $f 0.10$ 
tot $f 0.25$, al naar dat degene die het ontvangt, zich meer of minder groot wil voordoen.

Dergelijke dingen heeten eenvoudig ho hiule; er mede spelen.

Hiertoe behoort ook nog, dat een meisje wat spijs op een bord doet, en nu dit aan de een of andere jongeling geeft zeggende: dit is visch, of: dit is geld, of: dit is een kabaja, kortom, wat zij maar wenscht, in 't redelijke natuurlijk. De jongen moet dat nu teruggeven, hoewel niet dadelijk, vooral niet als visch of hertenvleesch of zoo iets van hen gevraagd wordt. Maar hij brengt het toch, en nu geeft het meisje hem voor zijn brengsel weer wat te eten, en noemt weer wat, waardoor een soort ridderdienst ontstaat. Dit is echter ook werkelijk maar een aardigheid, en b. v. volstrekt niet de inleiding tot een huwelijk. Het geschiedt meermalen tusschen personen, die zoo nauw met elkaar verwant zijn, dat van een huwelijk tusschen hen geen sprake zijn kan.

In het meest noordelijk gedeelte van het district Tobelo, 't dichtst aan de Galelareesche grens dus, hoorde men nog wel van: manga lou ja ihoro: "hun voeten zijn gewasschen». Men verstaat daaronder een soort huwelijksvorm, nl. dat de jongelui naast elkaar gaan zitten, waarna door een persoon beider voeten met water begoten worden. Men beweerde echter steeds, dat dit Galelareesche adat en geen Tobeloreesche was.

Misschien is dit wel een navolging van de Ternataansche gewoonte. Zoo men weet zijn de Ternatanen Mohammedanen, maar toch bestaat bij hen nog een oude huwelijksvorm. Nadat n.l. het huwelijk op Mohammedaansche wijze gesloten is, wordt een pol gras binnen gebracht, en man en vrouw zetten nu elk een voet, naast elkaar, op dien pol gras: 'gezamenlijk den grond drukken», noemt men dat, en dat is het huwelijk "toeroet adat tanah».

$\mathrm{Na}$ afloop van dit huwelijksfeest, wordt de jonge dochter meegenomen naar het huis van haar echtgenoot. Dit moet gebeuren onder veel tegenstreven.

Twee vrouwen uit de mans-familie, houden haar van weerskanten bij de hand en trekken haar mede, terwijl de bruid snikt en klaagt en tegenstreeft.

In 't geen nu volgt, is ook al heel veel verschil. Soms gaat de bruid eenvoudig mee, en later viert men feest. Maar ook geschiedt het wel aldus, dat hẹt ẹersțe medẹnemen dadelijk 
een heel plechtig karakter heeft: manga modoka jo hingòhama: zij brengen hun schoondochter binnen.

De bruid wordt dan feestelijk opgetooid, en geplaatst onder een soort troonhemel - een sarong aan de vier hoeken aan stokken vastgebonden, aan weerskanten door twee dragers vastgehouden - gaat men langzaam vooruit, de mannen zingen de lego-lego en al de vrouwen uit de familie volgen met de "kiaro" = de uitzet der bruid. Deze bestaat uit veel rijstkoeken, veel manden met brandhout, mooie matten, mooie vuurtangetjes, gevlochten hangertjes voor die vuurtangetjes, mooi gekleurde bezems van aren-palm-bladnerven enz. enz., alles wat zoo tot het departement der vrouw behoort, in kwistigen overvloed. De rijst behoort daar ook toe want de vrouw makt den tuin. De mans-familie zal straks dat alles verdeelen, want elk heeft ook wel bijgedragen tot den bruidschat.

Zoo'n optocht is wel een aardig gezicht. Natuurlijk is de trom en de gong erbij, want zonder de klanken van die instrumenten viert een Tobelorees nu eenmaal geen feest.

Zoo begeeft men zich dus langzaam naar het huis van den bruidegom. Wat nu verder gebeuren zal, is plaatselijk ook al heel verschillend. Op Tobelo zelf ging de jonge dochter haar nieuwe schoonfamilie allemaal pinang presenteeren, met een uiterst stijf gezicht en gebogen houding. Men ging ook wel de huizen der verschillende familiehoofden langs, opdat de nieuwe schoondochter overal haar dienstvaardigheid betoonen zou, vooral aan elk die tot den bruidschat bijgedragen had. Daarna volgde weer een feest, waarbij de jonge dochter stil zat, opgepronkt met alle mooie kleeren en versierselen, die de nieuwe familie maar bij elkaar wist te brengen, om haar grootheid te toonen.

Bij de Kausche Tobelo's was het gewoonte, dat de heele schoonfamilie zich opstelde in twee rijen tegenover elkaar. De nieuwe schoondochter met de geopende pinangdoos in haar hand, knielde, en werd nu links en rechts geflankeerd door twee mannen, die een kapmes of zwaard in de hand hadden, die zij gekruist boven de jonge vrouw hielden. Deze moest nu onder die zwaarden voortkruipende, de pinangdoos aan elk familielid presenteeren. Dat is natuurlijk zeer vernederend. Bij de Tobelo's zelf zag ik dat ook niet, alleen, dat zij in een onderworpen houding de pinang presenteerde aan de familie, die rondom op de bank in de gaanderij gezeten was. 
Bij de Kausche Tobelo's heeft men de gewoonte, dat de bruid terstond op een bank gaat zitten, en men nu haar de mooie kleeren dadelijk uittrekt, en aan haar familie teruggeeft, en vervangt door eigen kleeren.

Dat doen de Tobelo's ook, want de mooie kleeren waarin de bruid komt aanwandelen, hooren niet tot den uitzet, maar men doet het niet zoo ruw.

In sommige dorpen der Kausche Tobelo's, moet de bruid op de bank blijven zitten tot vier dagen lang, volgens eenigen. $\mathrm{Z}_{\mathrm{ij}}$ mag gedurende dien tijd de aarde niet beroeren. Moet zij toch loopen, dan moeten haar voeten omwoeld worden met sarongs. Zij moet gedurende al dien tijd stil zitten, met gevouwen handen, en voorovergebogen hoofd, mag niet praten, en gedurende de eerste paar dagen ook niet eten. Een oude vrouw zit dicht bij haar, om haar te bedienen of te bemoederen.

$\mathrm{Na}$ die vier dagen komt zij van haar bank af, en kookt voor haar schoonfamilie nu spijze, totdat elk.van het door haar gekookte gegeter heeft. Natuurlijk, dat ook even lang de huwelijksfeesten voortgezet worden.

Bij de Dodingaers is de adat wel wat omgekeerd; de vrouw brengt n.l. niet haar uitzet mee, maar zij ontvangt allerlei, kussens, matten, etc. opdat dit als anker dienen zal, en haar binden aan de nieuwe schoonfamilie. $Z$ ij zit daar ook gedurende zeven dagen of langer, terwijl een oude vrouw haar gestadig onderwijst, in haar plichten als getrouwde vrouw. Eerst als zij geacht wordt die te kennen, mag zij opstaan, en men leert haar nu loopen en werken, alsof zij een klein kind ware.

Ofschoon dit alles $n u$ door Tobelo's gedaan wordt, en men zelfs aan elkaar tegenovergestelde gewoonten onder hen aantreft, is toch wat nu gebeurt bij de Kausche Tobelo's en Dodingaers, wel niet oorspronkelijk Tobeloreesch, maar aangezien deze lieden, andere stammen langzamerhand uit hun woonplaatsen verdrongen, kan wen wel aannemen, dat zij vele gewoonten van die verdrongen stammen, ook in deze materie, bij de hunne gevoegd hebben. $\mathrm{Nu}$ is het mogelijk, dat men bij de «kiaro»: het uitzet der jonge vrouw, ook dadelijk meebrengt de "himanga»: het tegengeschenk voor den bruidschat.

Oorspronkelijk is dat adat geweest, in den tijd toen de bruidschat nog klein was en het tegengeschenk evenzoo. Later, toen men de bruidschat meer en meer begon op te drijven, en ook 
het tegengeschenk in verhouding daartoe steeds vergroot werd, is het langzamerhand gewoonte geworden, om dat pas later te brengen met een nieuwe feestelijkheid, o himanga jo totaka: zij brengen het tegengeschenk. Het brengen van dat tegengeschenk is echter niet verplicht, men kan het evengoed nalaten, maar verstandig is dat niet, want alleen het tegengeschenk doet de bruidschat wegzinken: ja lutu.

Het is n.l. aldus: de bruidschat is niet zoozeer een geschenk (koopsom) als wel een soort standgeld. Men zou kunnen zeggen: de twee families hebben voorloopig geruild, de een heeft een dochter gegeven, de ander een geldsom; echter, als de dochter zich misdraagt, wordt de ruil ongeldig gemaakt, de dochter keert terug tot haar familie, de bruidschat naar de oorspronkelijke gevers. De vrouw is niet los van haar stam, want ook behoudt zij het recht op het vruchtgebruik van de familieaanplantingen en -gronden. In dezen toestand komt echter radikaal verandering door het tegengeschenk. Zoodra dat gegeven en aanvaard is, is de vrouw geheel overgegaan aan de nieuwe familie. Zij heeft nu geen recht meer op haar familiebezittingen, en, zelfs al pleegt zij overspel, zoodat het huwelijk ontbonden wordt, dan kan de bruidschat niet meer teruggevorderd worden. Het recht daartoe is door het tegengeschenk opgeheven. Het is dus als vanzelfsprekend, dat alleen reeds de voorzichtigheid eene familie drijft dit tegengeschenk te geven, ook al is het niet verplichtend. Het bestaat nooit uit geld, maar hoofdzakelijk uit rijst, borden, kommen, etc.

Nevens deze geordende wijze om tot een huwelijk te komen, zijn er natuurlijk ook nog wel ongeordende, hoewel die niet rechtstreeks tegen den adat zijn.

Het lari-bini, zooals in het Ambonsche om te ontkomen aan al de kosten, die het geregelde huwelijk meebrengt, kent men als zoodanig niet, want men ziet hier niet tegenop, aangezien men heel gaarne groot doet, en zich voor een tijd de held der handeling weet.

Toch loopt men wel met een meisje weg, b.v. om den tegenstand van haar ouders te overwinnen.

Komt de tegenstand van den kant van de familie van den man, dan is de gebruikelijke weg, dat hij zich eenvoudig naar het meisje begeeft, en voortaan als getrouwd met haar wordt beschouwd. De rest komt dan later wel in orde, vooral als uit 
een zoodanig huwelijk kinderen geboren worden. De mansfamilie weet dan, dat die kinderen haar niet toebehooren, als geen bruidschat betaald wordt, en betaalt daarom dus later wel.

Echter, wil de familie van het meisje niet, dan is de weg dat hij haar ontvoert: wo mi hioara, hij loopt met haar weg. Soms gebeurt dit bij dag, en men begeeft zich tezamen naar het huis van een bekend familielid, van waaruit men de onderhandelingen laat beginnen. Gewoonlijk is dan het meisje reeds beschaamd om terug te keeren, zoodat daardoor de onderhandelingen tot een goed eind komen.

Ook wel houdt zich de familie van het meisje voorloopig nog kwaad, maar dit is maar adat, later komt alles terecht, het jonge mensch gaat een verzoeningsbezoek brengen bij de schoonfamilie, en het komt in orde.

Ook gebeurt het dat het meisje des nachts ontvoerd wordt.

Bij de inrichting der Tobelosche huizen, waar geen sloten aan de deuren zijn, is dat geen groote kunst. In den regel heeft zich het paartje nu hier of daar naar een stille plaats begeven. Heeft nu het jonge mensch maar eenig teeken achtergelaten, waaruit blijkt wat er gebeurd is, dan is het niet heel erg. Men weet toch wel zoowat wie het is, en wacht nu maar tot ze hier of daar te voorschijn komen. Gewoonlijk zijn ze ergens in een afgelegen tuinhuis. Na de ontdekking komt ook dit wel in orde, hoewel het natuurlijk minder netjes is dan het vorige geval, en er nu al dikwijls een boete geeischt wordt boven den bruidschat.

Maar nog erger is wanneer geen teeken achtergelaten wordt, zoodat niet de minste aanwijzing er is, waar men moet zoeken. Bij ontdekking des morgens dat het meisje weg is hebben nu heftige tooneelen plaats; de vader tracht zich uit werkelijke of voorgewende woede van kant te maken, men maakt gerucht, geeft kennis aan de hoofden, er wordt ernstig gezocht, en hoewel ook dit gewoonlijk op een huwelijk en op latere betere verstandhouding uitloopt, acht men het toch bepaald een ernstige overtreding van de adat, die ook, bij ontdekking, zwaar beboet wordt.

Natuurlijk is in de laatste twee gevallen het huwelijk - immers slechts het openbaar als gehuwden leven - reeds een feit geworden.

$\mathrm{Nu}$ komt het voor, dat men zich daar niet aan stoort, maar 
gewoonte is dat men zich bij het feit neerlegt. Langzamerhand komt het paartje weer in het dorp, en hoewel de kwaadheid voorloopig het aannemen van een bruidschat verbiedt, komt het toch wel in orde op den duur.

Maar een veel ergere vorm is het rooven van de vrouw: ha ora.

Dat middel neemt men gewoonlijk te baat, ook tegenover een onwillig meisje, maar meer nog ten behoeve van een man die al veel blauwtjes geloopen heeft, of om een of andere reden te bedeesd is, om een meisje of een vrouw te vragen.

Het meisje of de vrouw wordt dan onder het een of ander voorwendsel in de nabijheid gelokt van een huis, waar familie van den haar tot vrouw wenschenden man woont, en plotseling beetgepakt, soms doordien een vrouw een wijden sarong over haar en zichzelf heengooit, en haar daardoor het voortgaan belemmert, en in het huis gebracht, niettegenstaande haar hevig geschreeuw en tegenstreven. In dat huis wordt zij opgesloten gehouden hetgeen niet eens zoo gemakkelijk is in een Tobelosch huis, soms op een vlierinkje. $Z_{\mathrm{ij}}$ tracht op allerlei manier te ontvluchten, maar wordt streng bewaakt, door vrouwen natuurlijk. Heeft zij een mes bij zich, dan mag zij dat wel gebruiken. Men tracht nu haar het huwelijk voor te stellen en haar over te halen daarin toe te stemmen. Natuurlijk komt haar familie er al gauw achter, wat er met haar gebeurd is, en deze komt nu gewapend opzetten om haar te bevrijden. Maar van den kant der mansfamilie tracht men de ontstemde familie te overreden in de zaak te berusten, en een bruidschat aan te nemen, waarmede de zaak wel afgeloopen is, niettegenstaande het tegenstreven der vrouw. Maar lukt dit niet en het gelukt lang niet altijd, dan gaat het verkeerd; Tobeloreezen zijn heet gebakerd en men maakt nu van de wapenen gebruik, tracht het huis te bestormen om de gevangen gehouden vrouw te bevrijden, terwijl men van den anderen kant tracht dit te beletten, het is een spektakel en een geschreeuw dat verbazend is en waarbij soms ook wel ernstige verwondingen worden opgeloopen. Gelukt het het meisje te bevrijden, of gelukt het de schoone haar bewakers te verschalken dan is het afgeloopen. Echter gelukt dit niet binnen drie dagen, dan moet men de vrouw vrij geven. Is men nu niettegenstaande al het spektakel, nog niet bereid om de vrouw ten huwelijk te geven, dan moet de vrouw of haar familie, een boete betalen.

Dat laatste is wel het vreemdste van het geval, want dat be- 
vredigt ons rechtsgevoel heelemaal niet. Komt de vrouw vrij, voordat de drie dagen om zijn, dan wordt de roovende familie aangeklaagd en beboet wegens de rooverij. Maar het is alsof men, als men het drie dagen kan volhouden, daardoor een recht op de vrouw krijgt.

Het is een zeer ruwe gewoonte, die alleen past bij nog heel onbeschaafde toestanden. Men is er zeker niet toe gekomen door gebrek aan vrouwen want bij de Tobelo's bestaat dat niet, wel eenigermate bij de Kausche en Dodingasche Tobelo's, tenminste volgens de statistieken der Zending. De gewoonte bestaat overigens ook bij de Galelareezen.

Omtrent de andere stammen van Halmahera is mij op dit gebied niets bekend.

Ook hoort nog tot den adat het huwelijk zonder betaling van bruidschat waarbij de man eenvoudig bij zijn schoonvader in huis komt, en nu daar een meer of min ondergeschikte positie inneemt. Hij doet nu mee aan het tuinen maken, gaat mee varen en visschen, kortom hij makt zich nuttig in het gezin des šchoonvaders, ai toroaika wo wohamika, hij gaat bij zijn schoonvader in.

Soms gaat dit goed, maar zelden op den duur en dan ontstaat er twist. De man wil dan zijn vrouw meenemen en op zichzelf gaan wonen, maar de schoonvader eischt nu den bruidschat op. De schoonzoon beroept zich op den verrichten arbeid. Het gaat er nu maar om of zijn vrouw op zijn hand is of niet. Is zij hem genegen, dan gaat zij wel met hem mee, maar zoo niet, dan blijft zij bij haar ouders. In de meeste gevallen ontstaat toch later moeite over de kinderen, omdat die den bruidschat volgen, d.w. z. is de bruidschat betaald, dan hooren zij bij de mansfamilie, zoo niet, dan hooren zij bij de vrouwsfamilie. De billijkheid brengt nu wel mee, dat den man zijn arbeid of verblijf ten huize van zijn schoonvader als bruidschat aangerekend wordt, maar men is in deze dingen hoogst zelden billijk.

Ook is er een vorm, waarvan dikwijls weduwen met maar een dochter gebruik maken. $Z_{\text {ij }}$ weigeren n.l. den bruidschat te ontvangen, maar bedingen zich daarvoor het levenslang verblijf ten huize van haar schoonzoon. Dikwerf gaat dit heel goed, en het contract is voor beide zijden voordeelig. De weduwe zou immers den bruidschat, zoo zij dien ontving, met hare familie moeten deelen, en zou zelf zoo goed als niets daarvan krijgen. Bij haar 
dochter inwonende, verdient ze wel zelf den kost door tuinen te maken etc., maar ze heeft nu toch een dak boven haar hoofd, en verpleging in ziekte of ouderdom van haar kinderen of kleinkinderen. Deze verpleging wordt wel geregeld als bruidschat gerekend, zoodat het recht van den vader op de kinderen er niet door aangetast wordt.

Een vorm, die ook nog al veel voorkomt, is die, waarbij slechts een gedeelte van den bruidschat betaald wordt, of ook wel, die heelemaal niet voldaan wordt, onder beding dat het eerste meisje uit het huwelijk voortkomende, den bruidschat zal betalen. Men komt echter wel overeen hoe groot de som is, en wordt nu het meisje later ten huwelijk gevraagd, dan wordt dadelijk de vastgestelde som geeischt, die altijd al hoog is, want men belooft gemakkelijk natuurlijk, of wel, als het een gedeelte van de som is, legt men dat eenvoudig op den bruidschat: a mi djadji, hetgeen voor haar beloofd is. Huwt deze dochter zonder dat de som voldaan is, dan volgt onherroepelijk een aanklacht.

Het schijnt, dat men dit wel doet, om op den ouden dag nog wat in het vet te hebben, van des schoonvaders kant natuurlijk, van den kant des schoonzoons is het een teeken van armoede.

\section{HOOFDSTUK 17.}

\section{Het huwelijksleven en echtscheiding.}

Het spreekt van zelf, dat de betaalde bruidschat den man tot heer maakt. Er komen niettegenstaande dat toch wel pantoffelhelden voor, maar groot is hun aantal niet.

De vrouw moet heel veel arbeid voor haar rekening nemen, in de eerste plaats het tuinen maken.

$\mathrm{Nu}$ moet opgemerkt worden, dat de Tobeloreesche vrouw over het geheel volstrekt niet lui is. Als niet ongunstige omstandigheden, b.v. b. zeer langdurige droogte, er toe medewerken, heeft haar gezin, door haar arbeid, geen gebrek aan yoedsel.

Een goed echtgenoot helpt zijn vrouw nu wel hierbij, vooral bij een eerste ontginning, door het bosch om te hakken en het zwaarste werk te doen, maar toch blijft er voor haar altijd heel veel arbeid over om in de behoefte van het gezin te voorzien.

Dl. 77. 
Ook zorgt zij er voor, dat het erf rondom de woning, en de woning zelf steeds behoorlijk geveegd zijn, zoodat een Tobeloreesch erf er over het geheel niet onknap uitziet.

De man is daarentegen verplicht in de eerste plaats te zorgen voor toespijs, visch of vleesch. Verder moet hij zorgen voor sagoemeel, indien dat noodig is, en vooral in tijden van droogte, heeft men daar behoefte aan, daar dan de voortbrengselen van den tuin niet voldoende zijn.

Dan moet hij zorgen voor tabak of voor geld om die te koopen.

Ook voor kleeding, maar toch wordt die ook wel gekocht van de opbrengst van den tuin, vooral van den rijsttuin want men maakt een rijsttuin hoofdzakelijk om de rijst te verkoopen. Daar nu de man hieraan ook medewerkt, en de rijsttuin, dus wel zoowat als gezamenlijk bedrijf beschouwd kan worden, gebruikt men ook de opbrengst om gezamenlijk kleederen of versierselen aan te schaffen.

Verder moet de man zorgen voor geld, hij moet ho mentjari: geld zoeken. Hij doet dat op allerlei wijze, ò door zich bij iemand in dienst te begeven: o hewa h'olomo, ò wel door dammar te gaan halen op de eilanden Morotai, Batjan of Obi; de Kausche Tobelo's zoeken dat product in 't binnenland van $\mathrm{Kau}$, of langs de baai van Dodinga.

Of wel duikt men naar parelschelpen of gaat andere schelpen zoeken, die verkoopwaarde hebben, zoowel dicht bij huis, als bij de eilanden Mojau en Tofure, halverwege Celebes, en blijft daarvoor van maanden tot jaren weg.

Geld is altijd noodig ìn voor kleederen en versierselen, $\grave{n} n$ voor belastingen, maar vooral voor het betalen van bruidschatten en, te zijner tijd, ook van boeten.

Natuurlijk heeft de man ook de zorg voor den bouw en het onderhoud van het huis, en verder voor het maken van aanplantingen, 't zij van cocos- of sagoepalmen.

Wat nu betreft den eigendom van het in 't huwelijk verkregene, men kan daarvan moeilijk spreken als gezamenlijk bezit. Elk der echtelieden heeft zijn eigen beurs. De man ontvangt natuurlijk het meeste geld, en is daar ook volkomen baas over, zijn vrouw heeft daar niets over te zeggen. Maar wel heeft desnoods de man te gebieden over het geld of de eigendommen der vrouw. En neemt hij zijns vrouws geld of de kleederen die zij voor haar eigen geld gekocht heeft, dan begaat hij geen misdaad. 
Het kwam voor b.v., dat de man overspel gepleegd had, en op aanklacht der vrouw daarvoor beboet was, maar nu heel cynisch de kleederen van zijn vrouw te gelde maakte, om de boete te betalen.

Maar de man is ook aansprakelijk voor schulden, door zijn vrouw in toko's gemaakt, als hij tenminste niet van te voren het tegendeel gezegd heeft. Ook is hij aansprakelijk voor boeten, waartoe zijn vrouw veroordeeld wordt, behalve boeten voor overspel natuurlijk, want die worden door de vrouw's familie betaald, of door dengene met wien ze overspel pleegde; maar het kwam voor, dat een man zich beklaagde door zijn vrouw niet goed behandeld te worden, slecht verzorgd, of wel te erg uitgescholden, en dat daarvoor de vrouw door de Hoofden beboet werd. Wilde hij nu niet de schande hebben, dat zijn vrouw aan den openbaren weg te werk gesteld werd, dan moest hij zelf nog de boete voor haar betalen. Immers, het is "zijn vrouw», zegt men bij zulk een gelegenheid, en in die uitdrukking zit het heelemaal, want het zegt zoowel dat hij voor haar op moet komen in betaling, als wel dat zij volkomen bezitloos is.

Gewoonlijk behandelt de man zijn vrouw goed, maar niet altijd.

$\mathrm{Hij}$ heeft eigenlijk volkomen het recht haar te slaan. Men zegt dan eenvoudig: hij geeft haar harde onderwijzing: o d o d o t o ko ma dogowini, en dat is niet verboden, mits het niet al te is, b.v.b. dat hij haar geen erge wonden toebrengt, want dan is de onderwijzing te hard, en kan de man beboet worden.

Maar men verstaat al heel veel onder: onderwijzing, die natuurlijk altijd moet dienen om de vrouw onderworpen te maken, want de Tobeloreesche vrouw is over het geheel genomen nog al brutaal, en geeft haar meening met veel gemak te kennen. Maakt men een man aanmerkingen over zijn ruw en brutaal optreden, dan kan men hooren: nu, wat zou dat, ik sla toch maar mijn geld! Dit met het oog op de betaalde bruidschat natuurlijk.

Man en vrouw spreken elkaar gewoonlijk aan als dodiau: makker, gezel. Over elkaar sprekende, zegt men dat ook wel: ahi dodiau, ngohi dodiau mijn man, mijn vrouw, maar toch ook wel: ahi rokata, mijn man, en ngohi hekata, mijn vrouw.

Zijn er echter kinderen, dan benoemt men elkaar over en weer, als vader en moeder van de kinderen en spreekt elkaar ook aldus aan. 
Heet het oudste kind Dominggus, dan noemt hij zijn vrouw o Dominggus ngoi ajo: moeder van D., en zij noemt hem o Dominggus ai a ma: vader van D. Men noemt dus elkaars naam nooit, ook niet tegenover derden, en doet men dat, dan is er wat aan de hand, men beklaagt zich over elkaar, of dringt op scheiding aan. Komt de vrouw van Galela met het zeggen: ik wil spreken over Galela, of de man van Huru zeggende: ik wil spreken over ngo Huru, dat beduidt dit hoogstwaarschijnlijk dat men elkaar niet meer als man en vrouw erkent.

De huwelijken bij de Tobeloreezen zijn over het geheel zeer vruchtbaar. Men heeft heel gaarne kinderen. Een vrouw die niet baart, wordt een doode banaanstam genoemd, en onvruchtbaarheid is zelfs een geldige reden tot echtscheiding.

Hoewel men zeer gaarne jongens heeft, zijn toch meisjes volstrekt niet in minachting. Immers zij zullen straks een bruidschat aanbrengen.

Abortiefmiddelen kent men, maar zij zijn bij de eigenlijke Tobelo's niet gebruikelijk, ook niet als er zwangerschap ontstaat buiten het huwelijk. Mij is maar één geval bekend ervan; een jong meisje was zwanger bij een jongen die haar in den steek liet, en haar moeder was daarover zoo verontwaardigd, dat zij het meisje een abortiefmiddel ingaf, en de vrucht afdreef, ofschoon de zwangerschap reeds heel zichtbaar was. Men sprak van deze daad echter algemeen met afkeuring.

Helaas kan dit gunstig getuigenis niet gegeven worden van de Kausche Tobelo's. Bij die heeft men heel veel onvruchtbare huwelijken, en schijnt men ook meer afdrijfmiddelen te bezigen.

Echter, voor die onvruchtbaarheid is ook nog een natuurlijke oorzaak. De moeders daar hebben voor hun zoons nogal een apenliefde, en zijn bovenal bang, dat zij niet genoeg te eten zullen hebben. $\mathrm{Zij}$ doen daarom al hun best, hun nog jonge zoons, te doen trouwen met $\min$ of meer bejaarde vrouwen, weduwen desnoods, omdat die gewoonlijk beter tuin maken dan een jong meisje. Maar natuurlijk, het ongelijke in leeftijd, bevordert de vruchtbaarheid niet. Sterft nu deze vrouw, dan is de man dikwijls al min of meer op jaren, en laat zich nu niet meer door zijn moeder een vrouw aanpraten, maar kiest zelf naar eigen smaak, en nu gewoonlijk een piepjong ding, tenminste in vergelijking met hem. En natuurlijk, hoewel de kans op kinderzegen nu grooter is, is toch ook weer het verschil 
in jaren een ernstig beletsel. Toch heb ik daar ook heel wat paren gekend, elkaar niet ongelijk in jaren, maar toch kinderloos.

$\mathrm{Nu}$ heeft de vrouw het bij de Kausche Tobelo's beslist veel moeilijker dan bij de Tobelo's in Tobelo zelf. Gaf men van de Tobelo's een dochter daar ten huwelijk, dan werd men verleid door de zeer hooge bruidschat maar men vond het toch altijd bezwaarlijk met het oog op het meisje, omdat de Boengs zoo ruw waren.

De zeer hooge bruidschat was bij de Kausche Tobelo's, het gevolg van hun wonen aan de Kaubaai, waar veel parelbanken gevonden worden.

Het parelduiken had velen zeer rijk gemaakt, en het gevolg daarvan was weer, dat men gaarne heel groot deed met de bruidschat. Dit verleidde wel eens sommigen, maar Tobeloreesche ouders die het goed met hun dochters meenden, gaven ze niet gaarne hier ten huwelijk, hoewel ze om hun vruchtbaarheid zeer begeerd werden door de Kausche Tobelo's.

Hoewel wij dit nog niet gezegd hebben, volgt toch al wel uit het medegedeelde, dat de Tobelorees monogamist is, echter met deze reserve, dat het vroeger wèl toegestaan was, naast de wettige vrouw bijvrouwen te hebben. Dat moesten echter slavinnen zijn, of liever krijgsgevangenen, geen Tobeloreesche vrouwen. Ook was nog wel de toestemming der eigen vrouw noodig hiertoe, en de adat bepaalde nu het geregeld zich wijden van den echtgenoot aan al die verschillende vrouwen.

Maar men kreeg wel min of meer den indruk dat dit een voorrecht was, dat de mannen zich op de vroegere krijgstochten toegeeigend hadden, in tijden van verwildering, want het streed volkomen tegen het Tobeloreesch idee. Immers, de vrouw heeft, volgens de adat, het recht, dadelijk weg te loopen, indien haar man zich met een ander ophoudt. Dat gaat nu met polygamie niet gepaard natuurlijk. Ook was de gewoonte volstrekt niet algemeen, en het oordeel erover was niet gunstig.

Ik heb nog mannen gekend met meer dan één vrouw, een zelfs met vier. Een was de hoofdvrouw, zij noemden elkaar zuster en mochten wel in één huis samenwonen, als zij niet met elkaar twistten.

De kinderen uit die vrouwen geboren, hadden gelijke rechten. Tijdens mijn verblijf te Tobelo is mij maar eenmaal bekend 
geworden, dat een man twee vrouwen nam. Hij was de zoon van het Hoofd, dat met vier vrouwen leefde. Men trok echter algemeen den neus op voor vrouwen, die zich tot zooiets leenden. Vrouw $\mathrm{N}^{0} 1$ was een zwak schepsel dat het wel niet aandorst zich te verzetten, temeer niet omdat zij geen mannelijke familie had, die haar partij nam, en vrouw $\mathrm{N}^{\circ} 2$ was een deern, die wegens haar lichtzinnig gedrag door de meeste ouders wel niet als schoondochter begeerd werd.

Men yertelde nog altijd met een soort leedvermaak, dat een vroeger Districtshoofd, dat met vier vrouwen gehuw.d was geweest, slechts een dochter had nagelaten. Men vond dit wel een soort straf voor zijn lichtzinnig gedrag.

Men zegt dus niet te veel, wanneer men beweert, dat de Tobelorees monogamist is, want voorkomende gevallen van polygamie zijn als excessen te beschouwen, en niet in den adat gegrond.

Wat betreft de huwlijkstrouw, kan het getuigenis nogal gunstig zijn, met dien verstande, dat ontrouw gemakkelijk een verbreken van het huwelijk ten gevolge heeft.

Wij zeiden, dat in sommige dorpen de a.s. schoondochter en ook de schoonzoon, onderwezen worden in wat ze als schoondochter en als schoonzoon verplicht zijn. Natuurlijk betreft dat gedeeltelijk de eerbied aan de schoonfamilie te betoonen, maar toch vooral de houding tegenover de andere kunne. Men is op dat punt al heel gevoelig, en een getrouwde moet uiterst voorzichtig zijn in zijn handelingen in gezelschap om niet te how o no: overtreden.

$\mathrm{Nu}$ is dat altijd wel niet van ernstige beteekenis, maar men schijnt toch zoozeer overtuigd te zijn van elkaars zinnelijkheid, dat men zeer nauwe grenzen getrokken heeft, om overtreding te beletten.

Veel wat bij ons niet erg zou zijn, het samen wandelen, het naast elkaar gaan zitten, het elkaar toeroepen, het bij ongeluk elkaar aanroeren enz., geldt reeds als overtreding. En zelfs bij vermoeden van een overtreding, volgt al een anklacht.

Wordt er bepaald overspel gepleegd door een man, en betrapt hem zijn vrouw, dan staat de adat haar toe, de overspelers te slaan met wat haar maar het eerst in de hand komt, ook zelfs wel met een kapmes. Dat komt echter zeer zelden voor. De man mag ook zoo handelen indien hij zijn vrouw betrapt op overspel. 
Gewoonlijk is dit echter het geval niet. Merkt de vrouw, dat haar man haar ontrouw is, dan gaat zij heen, verlaat de echtelijke woning, keert terug naar haar familie, en wacht daar af tot een rechtzaak aanhangig gemaakt wordt.

Is de man bepaald met een ander gaan leven, dan volgt echtscheiding, waarover straks. In het andere geval, keert zij niet terug voor haar man haar o maleke ma dadatoko: bedekking der schande, betaald heeft. Het oude recht staat echter aan den man toe, dit te doen zoo dikwerf hij verkiest. Keert hij terug met de schandebedekking, dan moet zijn vrouw zich dit laten welgevallen.

Is de man op reis, naar Batjan b.v., en hij vergaloppeert zich, dan zendt hij dikwerf al een schotel of zoo iets vooruit, om bij voorbaat het booze gerucht tot zwijgen te brengen, en zich weer een goede ontvangst te verzekeren. Zoolang hij dus niet beslist met een ander gaat leven, is zijn vrouw niet van hem los, al kan ook soms de boete of schandebedekking wel wat hoog worden. Hij zegt dan alleen maar: ik ken haar als mijn vrouw, en zij moet zijn vrouw blijven, of, als de schuldige partij, zelf scheiding vragen.

Er zijn mij gevallen bekend, waarbij de man inderdaad reeds op een andere plaats met een ander leefde, en toch de familie, wie dat niet aanstond, er op los ging, den man weer ophaalde en zooveel betaalde, dat de vroegere huwelijksband weer bestendigd werd.

Natuurlijk heeft de man dan niet met eens anders vrouw geleefd (zie het vervolg) maar met een weduwe of jong meisje.

Verder dan het recht op een schadevergoedering, gaat dus het recht der vrouw, bij schending van de huwelijkstrouw niet.

Heel anders staat het, indien de vrouw daadwerkelijk oyerspel bedrijft, en dus de huwelijkstrouw schendt. Er ontstaat daardoor een groot spektakel. De vrouw en de schuldige man vluchten zoo spoedig mogelijk naar het Hoofd van het dorp, nog beter naar het Districtshoofd, of wel, het Districtshoofd gaat er dadelijk op uit om hen gevangen te nemen, als ze zich hier of daar in een tuin verborgen hebben. Dit is noodig om moord van den kant van den beleedigden echtgenoot te voorkomen, want die heeft het recht zijn beleediger en zijn vrouw te dooden. Hijzelf klaagt ook niet aan, hij wil zich alleen wreken. Zijn broers gaan de zaak aangeven, en brengen het voor hem in 
orde. Het zou schande zijn indien hij kwam klagen bij de Hoofden, alsof hij zelf zijn zaak niet in orde kon brengen.

Het huwelijk is door dat feit dadelijk ontbonden; de beleediger moet den bruidschat vergoeden en bovendien nog een boete betalen en een som ter vergoeding van de gemaakte kosten, bij de Kausche Tobelo's zelfs het dubbele van de eenmaal gemaakte kosten.

Overspel van de vrouw doet dus het huwelijk te niet.

Van een adatstandpunt uit gezien, is dit ook volkomen in orde. De vrouw wordt door de bruidschat het eigendom van den man. Wel worden ook aan de vrouw nog eenige rechten toegestaan, zooals wij zagen, maar toch niet het recht om het huwelijk te verbreken. Immers, de vrouw gaat dat ook niet aan, zij wordt getrouwd, tot schoondochter gemaakt, zooals de term luidt. Maar maakt zich nu een ander meester van het recht, dat de bruidschat geeft, dan is dat recht daardoor geschonden, het is een soort diefstal, die dan ook door betaling wel weer in orde gemaakt wordt, maar aangezien nu een ander de bruidschat vergoedt, neemt deze daarmede ook de rechten op de vrouw over.

Het hoort ook tot de huwelijksplichten elkaar in ziekte bij te staan ho ma teke paliara, elkaar over en weer verplegen, zooals de term is. Men vindt dit vanzelfsprekend, maar toch wordt er tegen dezen plicht nogal heel wat gezondigd. Natuurlijk geeft dat bij een gewone ziekteaanval geen bezwaar, maar o wee als een der partijen aangetast wordt door een langdurige ziekte!

Ik heb voorbeelden gezien van opofferende trouw, ook in dat geval, mannen die een zieke vrouw niet verlieten, maar haar behoorlijk bleven verplegen, jaren lang. Ook mannen die aldus door hun vrouw verpleegd werden. Maar toch is dat helaas geen regel, hoewel het wel adat is. Er zijn echter heel veel zaken wel adat, d.w.z. men zegt wel: het hoort zoo, maar toch treft over het geheel, wie zich niet aan dien adat houdt geen blaam.

Wanneer een vrouw door ziekte getroffen wordt, vooral door wat men algemeen in de Molukken noemt sosiri, dan zou elk het den man kwalijk nemen, als hij geen medicijn voor zijn vrouw zocht, en haar niet bij verschillende deskundigen bracht, die den naam hebben deze ziekte te kunnen genezen. Maar, indien de genezing niet volgt, en de vrouw op den duur 
niet in staat is, om haar plichten als huisvrouw te vervullen, zoodat de man zelf water moet halen en koken, het erf moet vegen en wat dies meer zij, en zij geen tuin meer maken kan, nu, dan neemt niemand het kwalijk, indien de man zich van zijn vrouw terugtrekt.

Gewoonlijk gaat dit met volle toestemming van weerskanten, want, ook al heeft de vrouw bezwaren, dan zou zij zich nog te beschaamd gevoelen die te uiten. Merkt zij dat haar man haar liever kwijt wil zijn, nu, dan roept ze zelf wel haar familie en verzoekt deze haar mee te nemen. $\mathrm{Zij}$ keert dan eenvoudig naar haar ouders of naar haar broers of zusters terug. Het huwelijk is daarmede stilzwijgend ontbonden, en niemand neemt het nu den man kwalijk, indien hij naar een andere vrouw omziet.

En evenzoo, indien de man ongeneeslijk ziek wordt.

Hier is de zaak niet zoo gemakkelijk, omdat de vrouw toch met den bruidschat gekocht is, maar toch, als de man niet meer in staat is, door wonden of vergroeingen man te zijn voor zijn vrouw, dan gaat het huwelijk ook dikwijls van zelf uit elkaar. De man laat zich dan ook maar naar zijn familie brengen, vooral naar een zuster, als hij die heeft, en laat de echtelijke woning over aan zijn vrouw, waarmede het huwelijk ontbonden is. Ook dit gaat wel met overeenstemming van weerskanten.

Ik vroeg wel eens aan mannen, op die manier door hun vrouwen verlaten, hebt ge geen hartzeer omdat je vrouw weg is? en 't antwoord was dan: och, ik was toch beschaamd om haar te houden.

Het is dus van weerskanten wel gelijk. Men, d.w.z. de zieke, vindt het wel vreeselijk onaangenaam verlaten te worden, houdt dikwijls ook wel van de andere partij, maar helaas, de adat verbiedt dat te zeggen, omdat men daardoor in verdenking zou komen, den bijslaap niet te kunnen ontberen.

Toch is dit niet altijd de oorzaak, want men heeft ook wel dikwerf dieper genegenheid voor elkaar, maar de adat verbiedt, om dit te uiten.

Wil de eene partij niet meer, dan moet de andere zich groot houden en toestemmen, ook al zou het hart breken, dat eischt de adat.

Over het geheel gaat het wel met het huwelijk, maar het is vreeselijk los; wien het niet op geld aankomt, kan zoo gemakkelijk van vrouw wisselen. Men vindt mannen, die vijf of zes vrouwen achter elkaar gehad hebben. 
Echtscheiding is betrekkelijk zoo gemakkelijk en eenvoudig, wij hebben reeds verschillende gevallen ontmoet, waarbij die als uit den adat voortvloeit.

De man zegt maar tot zijn vrouw: to $\mathrm{ni}$ oluku, ik wil je niet meer, en het is eigenlijk afgeloopen. Volgt hieruit een rechtszaak, dan is dat over de gevolgen die eruit voortvloeien, maar de scheiding is hiermede een voldongen feit.

Die gevolgen zijn, een deeling van de goederen, maar hierbij is groot verschil. Is er een schuldige partij, d. w. z. heeft een der partijen zich schuldig gemaakt aan overspel, dan krijgt die schuldige partij noch de kinderen, noch bruidschat. Is de vrouw de schuldige, dan moet de bruidschat terug betaald worden, en de kinderen is ze kwijt. Is de man de schuldige, doordien hij met een ander trouwt en zijn vrouw onschuldig is, dan is ook hij den bruidschat kwijt, en heeft geen recht meer op zijn kinderen. Het laatste houdt nog wel menigeen van een overijlden stap terug, want men is op de kinderen zeer gesteld, zooals wij reeds zagen.

Gewoonlijk willen ook de kinderen niets meer weten van een vader die hun moeder verstiet. $\mathrm{Zij}$ hangen in den regel sterker aan de moeder dan aan den vader.

Wordt door den rechter een scheiding uitgesproken op verzoek van dę vrouw b.v., wanneer zij bewijzen kan dat haar man haar booswillig verlaat, haar te veel mishandelt, haar niet bijstaat met het tuinen maken, haar beleedigt door niet de spijze te willen eten die ze kookt, enz. dan wordt dat zinnebeeldig uitgedrukt, doordien de rechter een vuurtangetje: o kakatama, zijnde een bamboelatje, in 't midden geknakt en dubbel gevouwen, door midden breekt, en elk der partijen de helft toereikt.

$\mathrm{Zijn}$ er nog te veld staande gewassen, of wel is de pas geoogste rijst in de schuur, dan wordt dit zoo verdeeld, dat de man $1 / 3$, de vrouw $2 / 3$ krijgt. Is de man de schuldige, dan wordt aan de vrouw ook nog wel de echtelijke woning toegewezen, om met haar kinderen te bewonen. Dit alles is natuurlijk naar omstandigheden.

Bij verlating wegens ziekte of onvruchtbaarheid, is de man natuurlijk ook den bruidschat kwijt. De kinderen blijven in dat geval wel aan beide partijen behooren: ja kaika ja kaino, ze loopen heen en weer, want beiden hebben er evenveel recht op. Het gevolg daarvan is wel eens dat ze schromelijk verwaar- 
loosd worden, daar niemand er zich eigenlijk voor verantwoordelijk gevoelt.

De gescheiden vrouw, o dilikit u, wordt als zoodanig volstrekt niet geminacht. En het gebeurt ook nog al tamelijk dikwijls, dat de man later weer heel kalm met zijn gescheiden vrouw gaat leven, als was er niets gebeurd, wo mi higilioka, hij heeft haar teruggenomen, zegt men eenvoudig. Men ziet hierin niets ongepasts, dat is: o njawa moi o njawa moi manga hin inga, elks smaak, zouden wij zeggen. Vraagt men een derde of hij dat ook zou doen, dan klinkt het dikwijls: neen ik zou daar vies van zijn, maar hij voegt er dadelijk aan toe: echter elk zijn smaak in dezen.

Over het doen van een ander matigt men zich geen oordeel aan.

Het spreekt echter van zelf, dat dit niet plaats heeft bij scheiding wegens overspel der vrouw, alleen bij echtscheiding om andere redenen. Ook wordt er dan niet opnieuw een bruiloft gevierd of zoo iets, och neen, men doet eenvoudig alsof er niets gebeurd ware en leeft weer met elkander als man en vrouw.

Wordt de vrouw verstooten, omdat zij te oud is om op verderen kinderzegen te hopen, dan schijnt dat wel geen booze gedachten verder op te wekken, want ik heb er de voorbeelden van gezien, dat de vroegere vrouw met haar kinderen en de latere, heel goed samen leefden. Daaromtrent denkt men dus weer anders dan wij.

Ook bestaat er geen boosheid tusschen den man, die de gescheiden vrouw huwt, en haar vorigen man. Met de scheiding is het eenvoudig afgeloopen geweest.

\section{HOOFDSTUK 18.}

\section{Ziekten en geneesmiddelen. Vergift en vergiftigen.}

Er heerschen onder de Tobeloreezen helaas heel wat ziekten en kwalen.

Men heeft heel veel wonden, o gomuku, waaronder men verstaat wonden, ontstaan uit verzweringen, van het grondwoord o muku : rijp, zacht.

Van versche wonden spreekt men als van o nabo.

Een algemeen ziekelijke gesteldheid van het lichaam, waardoor 
wonden en zwellingen ontstaan, noemt men o boga-boga, en de verst gevorderde toestand van deze ziekte, waarbij allerlei verkrommingen ontstaan, en de patient zich bijna niet meer bewegen kan: o karana.

De frambosia noemt men o gerehi. Men beschouwt het als een geluk, als de kinderen die ziekte jong krijgen, daar zij dan het minst erg is. Een soort waarbij geen oppervlakkige wonden ontstaan, maar zeer diep ingevretene, en die dikwerf den dood ten gevolge heeft, noemt men o gerehi ma dorou: de booze frambosia.

Uit de gerehi, slecht behandeld, vloeit dikwerf de bogab o ga voort, het gaat als in elkander over, zoodat men het een wel als een voortzetting van het andere kan beschouwen.

Nablijvende voetwonden van de frambosia noemt men o batoko, met denzelfden naam, waarmede men voetangels benoemt, die natuurlijk ook de oorzaak kunnen worden van voetwonden.

Peesknoopen en zwellingen die daarop gelijken, noemt men o bobóótja, terwijl men een steenpuist of ook wel negenoog aanduidt als o boroho. (In het Galelareesch is dit het woord o boro: ei, en wellicht heeft het gezwel ook wel om zijn vorm dezen naam, hoewel men in het Tobeloreesch ei o goh i heet, en o boroho moot, snede beteekent).

Men spreekt ook wel van o siribara, en bedoelt daarmede dieper liggende gezwellen, ook wel gezwellen in de inwendige organen, die men dan nog weer onderscheidt in o bara ka rahe, als een muis zoo groot, o bara kan a ng a - erger dan het eerste - en o bara ihanga, als een plank zoo hard, de ergste soort.

De schurftachtige aandoening der huid, in het Moluksch Maleisch kaskado geheeten, en die nog al veel voorkomt, noemt men o uhaka.

Verder kent men als blaasjesuitslag o harapa en o gududi, beiden acuut, het laatste fijner dan het eerste.

Een puistjesuitslag heet o gudidi, ook acuut; een soort schubachtige uitslag is o hehega. Ook komen de mazelen voor, die men o howi noemt, en die dikwerf de oorzaak zijn van groote kindersterfte.

Pokken noemt men o luti, zeer gevreesd natuurlijk, terwijl men waterpokken oluti o a kere, letterlijk: waterpokken noemt. Een soort windpokken noemt men o luti ma dutua: onechte pokken. 
Een huidziekte, die witte plekken op de huid doet ontstaan, en die soms het voorkomen al heel komiek doet worden, zonder pijnlijk te wezen, noemt men o galula.

Nog kent men een soort schilferziekte aan de voeten, voornamelijk aan de voetzolen, waardoor pijnlijke wonden ontstaan; deze noemt men o wowoko.

Huidbloemen noemt men o horowai en o tugala. Men vindt deze heel mooi, vooral bij jonge meisjes.

Ook komt, als leelijkste ziekte, de melaatschheid voor, die men o pado heet. Men is er zeer bang voor, zonder toch de ziekte goed te kennen. Men zegt ook wel kortweg: o penjaki ma dorou, de booze ziekte. Men zegt van iemand, die ziek is, dat hij is ja hiri: ziek, hoewel men het woord hiri ook gebruikt om pijn aan te duiden, en diensvolgens spreekt men dan ook van hoofdpijn, buikpijn enz., als van o haeke jo hiri hoofdpijn, o mamata jo hiri buikpijn, enz.

Als bepaalde inwendige kwalen, kent men ten eerste i na gogama, de koorts hebben. Het woord beteekent natuurlijk: koud zijn, want men verstaat er het koude tijdperk van de koorts onder. Voor het heete tijdperk zegt men eenvoudig: ai roehe ja hauku, zijn lichaam is heet.

Bij bijzonder sterkte hitte spreekt men van o upaha, men zegt dan, dat door de hitte de milt uit den buik gedreven wordt, dus waarschijnlijk malaria met sterke miltzwelling.

Als soorten hoofdpijn noemt men o doduruka, scheele hoofdpijn, ook: o koloba, een pijn die zoo lang duurt als de koloba, de groote arend vliegt, dat is dus zoowat zoo lang als de zon aan den hemel staat.

Een soort scheurbuik noemt men o obi.

Alle ontstekingachtige borstziekten, zoowel pleuritis als longontsteking, noemt men i n a taga. Men denkt daarbij bijzonder aan de stekende pijn bij. het ademhalen, de belemmering in de ademhaling.

Alle aandoeningen van de luchtwegen noemt men kortweg o diikiti: hoest, hoewel men nog wel spreekt van teringachtige hoest als: odiikiti ma dorou, de booze hoest.

Kortademigheid, astmatische aandoeningen van de luchtwegen, noemt men o kaho ma wowomaha, hondenademhaling, waarbij men natuurlijk denkt aan het hijgen van een hond na een snellen loop. 
Eens kwam een jonge man bij mij met de mededeeling dat hij behond was. Hij was de zoon van een gomatere, en zelf ook al half zenuwpatient.

Op mijn verbaasde vraag, wat hij daarmede bedoelde, deelde hij mede, dat in zijn borst een hond zat; hij had dien meermalen gezien, het was een zwartbonte hond, die dwars over zijn borst lag. Overdag voelde hij hem wel, maar zag hem niet, maar des avonds, als hij even geslapen had, werd hij wakker door benauwdheid, en dan zag hij den hond liggen, Maakte hij beweging, dan ging hij weer naar binnen. De arme kerel was doodongelukkig. Ik heb hem als zenuwpatient behandeld, ik geloof wel met goed resultaat.

Is men alleen maar verstopt in het hoofd, verkouden, dan noemt men dat o hirangutu, naar het neussekreet, dat dien naam draagt.

Natuurlijk dat men ook bere-bere kent, hoewel die in het district Tobelo zelf niet voorkomt, maar wel bij de Kausche Tobelo's en op het eiland Morotai. Daar de ziekte zich het meest voordoet bij hen, die in het gebergte gaan om gom-copal of dammer te halen, kan men het gerust onder de hartziekten rangschikken, ontstaan door oververmoeing van het hart. Men is er ook zeer bang voor. Na een val of zoo iets, spreekt men als van iets heel gevaarlijks van: nanga ohu i kilioro, de maag is omgeschud. Wat men er onder verstaat, weet ik niet, maar men vond het altijd hoogst gevaarlijk en bedenkelijk.

Als buikziekten kent men: i $\mathrm{n}$ a horopu, buikloop; i na pokoro, dysenterie; o mamata ma dogowini, hard van buik, verstopt zijn; ook: ho matuwunihi, pijnlijke persingen in den endeldarm. Verder spreekt men van o $\mathrm{njoa}$, een soort buikziekte, waarbij men het gevoel heeft, alsof men een $\mathrm{nj}$ oa, een groote platvisch, in den buik had of heeft. Men meent wel zoowat van alles in den buik te kunnen hebben als: o tataulu, een zeekwal, o tali, een zeester, o mimiri, een z. g. n. millioenpoot, een geringde worm op vochtige plaatsen voorkomende, o papatjo, een schelpdier met spitse schelp, o ohungu, wespen, o pidilong, groote strandwormen, en verder zoo wat alle soorten van visschen, ook o gumilamo, de gevlekte pythonslang. Men krijgt natuurlijk bericht omtrent het aanwezig zijn van deze buikbewoners, door de gomateres, die ze kunnen zien.

Men spreekt verder van o hawakata, waaronder men wel 
een algemeen kramperig gevoel in den buik schijnt te verstaan; van: o siridola, misschien: globus. Ik zeg met opzet: misschien, omdat, waar de spraakmakende gemeente zelf de ziekten benoemt, er nogal eens groot verschil kan zijn, omtrent wat verschillende personen onder één naam aanduiden. Als een blaasaandoening kent men i na kihaueri, waarmede men gewoonlijk allerlei beletselen bij de urineloozing aanduidt. Als voorbehoedmiddel daartegen, en ook als middel daartegen, bindt men een biesje om den grooten teen en verbiedt het kauwen van suikerriet.

Ook spreekt men van o a u nu ho lohihi, bloedwateren, en o gomuku holohihi, etterwateren. Helaas zijn geslachtsziekten volstrekt niet onbekend, en ook druipersziekte komt heel wat voor. Men vertelt dan gewoonlijk dat men o gorona ja hiri, lendenpijn heeft.

Ook syphilis komt voor, hoewel men daarvoor alleen weet te zeggen: nauru ma penjaki, mannen- of mannelijk schaamdeelziekte.

Liesbreuken noemt men o lihiti; hoewel die niet heel veel voorkomen, kent men toch den naam algemeen, en is er bang voor, aangezien ze, daar men geen breukbanden kent, dikwijls den dood veroorzaken.

Ook kent men waterzucht, die men o hiri akere noemt, de waterziekte. Bij algemeene zwakte zegt men o bole-bole, langzaamheid, of o kangela vermoeidheid, afgematheid.

Nog kent men een ziekte, die veel voorkomt, vooral als bijverschijnsel bij zwaar zieken, en die men o dohuku noemt. Het woord beteekent: terugwijken, en men schijnt er onder te verstaan een krampachtige samentrekking van de aarsspieren, zoodat het is alsof de anus ver naar binnen getrokken wordt, en desgelijks van de spieren van de schaamdeelen en urinewegen, waardoor ook die sterk naar binnen getrokken worden.

Komt dit voor bij ouden van dagen, dan beschouwt men hun ziekte als hopeloos, bij jongere voorwerpen tracht men het te medicineeren.

Ik zag het o. a. bij jongetjes van vier tot acht jaar, waarbij het scrotum krampachtig saamgetrokken werd, de testis verdwenen in de buikholte en de penis verdween eigenlijk heelemaal, zoodat er niet dan een spleetje overbleef. Bij een oude vrouw, zag ik de schaamstrek zoozeer ingetrokken, dat van de 
schaamdeelen eigenlijk niets meer te zien was dan een diepe gleuf in de huid. Het is uiterst pijnlijk, de patienten schreeuwen hevig en onafgebroken, zoolang de aanval duurt. Heeling zag ik alleen door groote giften opium, ook door chloraal-hydraat.

Natuurlijk dat men ook nog namen heeft voor allerlei kleinere gebreken, als: fijt: o nauoko ma lako, vischoog, horrelvoet: o pahu, scheelzien: o lako i leri, enz. Voor bewusteloos zegt men: i na kiditoko, feitelijk: op het eind komen, op het kantje komen.

Van algemeen heerschende besmettelijke ziekten zegt men o bobaku, en o mularati.

Bij elkaar al heel wat ziekten die de menschen ongelukkig maken.

En hoe staat het nu met de geneesmiddelen die men tegen al deze kwalen kent?

$\mathrm{Nu}$, over het geheel kent men heel wat geneeskrachtige kruiden en wortels, waaronder er wel zijn, die de moeite waard zijn, en in een Europeesche apotheek geen slecht figuur zouden maken.

Of men sommige medicijnen uit een animistisch oogpunt vroeger heeft leeren gebruiken, weet ik niet, maar $n u$ brengt men dat wel niet meer tot uitdrukking.

Echter men kent in sommige gevallen uitstekende middelen.

Ik had een patient die leed aan waterzucht tengevolge van gebrekkige hartwerking, en, daar alle aangewende middelen niet baatten, vroeg men mij, het zelf te mogen probeeren. Men wist iemand, die er een middel tegen had. Ik had daar natuurlijk niets op tegen, en werkelijk, na een 14 dagen kwam de man bij mij, zoo goed als hersteld, en hij herstelde ook volkomen. Het middel gaf men mij op, en ik heb het later in gelijke gevallen, ook met succes gebruikt, of laten gebruiken.

Een ander, die vreeselijke dysenterie had, werd door een vrouw in een halve dag genezen met een soort wortel, die ze me ook noemde. Dezelfde vrouw had ook een middel tegen cholera, (waarschijnlijk bedoelde ze hevigen buikloop). Ik zag meermalen verschillende aftreksels met goed gevolg gebruiken tegen buikloop.

Een man die aangetast was door een hevigen hoest, zoodat men hem als teringpatient moest beschouwen, en hem moeilijk meer dan een maand of wat levens meer kon toezeggen, verscheen plotseling, volkomen hersteld. Helaas wilde de man die hem behandeld had, niet zeggen, welke wortel hij voor dat doel gebruikt had. 
Maar men kent werkelijk heel wat middelen, hoewel natuurlijk niet allemaal even doeltreffend. Sommige lieden hadden bepaald een goeden naam, als kenners van geneeskrachtige planten.

Natuurlijk was er ook heel veel bij, dat maar alleen op den naam af gebruikt werd, dikwijls omdat de naam van de plant met die van de ziekte overeenstemde, of om een of andere eigenschap, b.v. bij het genoemde dohuku, het krampachtig naar binnen trekken van anus en geslachtsdeelen, gebruikte men jonge spruiten van het alang-alang gras, omdat dit verbazend snel uitschiet, naar buiten komt, dus moeten ook daardoor de ingetrokken deelen naar buiten komen.

Een zekere vetplant, o ma mata, koude, geheeten, moest bij koortshitte gebruikt worden, om koude te doen komen, enz.

Het ergste van het geval was, dat elk een of twee medicijnsoorten kende, maar niemand een diagnose wist te stellen. Ergo, was men ziek, dan ging men naar iemand die een medicijn kende dat den een of ander geholpen had, en kocht dat medicijn, of liet er zich mede behandelen.

Dat nu degene die door het medicijn genezen was, een andere kwaal had gehad, daarnaar vroeg men niet. Het was een goede medicijn (o houru) dus probeerde men het daarmede maar. Hielp dat niet, dan maar weer naar een ander, die ook een medicijn had. Daar het echter op die manier nog al lang kon duren, eer men de goede medicijn te pakken had, ging menigeen dood, nog steeds zoekende naar het voor zijn kwaal passende middel. Want, wanneer ik zeg, dat men mij mededeelde, welk medicijn men gebruikte in een zeker geval, dan was dat alleen omdat ik me toen bewoog onder een Christenbevolking. Onder de Heidensche bewaart elk wel zijn eigen geheim, om er te gelegener tijd geld uit te slaan.

Kort voor wij van Tobelo vertrokken, was ik begonnen bij alle Christenen een onderzoek in te stellen omtrent wat men wist in dezen, en het resultaat daarvan wilden we in alle scholen aanplakken, zoodat men overal een lijst had, welke geneesmiddelen in een bepaald geval konden gebruikt worden. Of het plan verder tot uitvoering gekomen is, weet ik niet, maar het scheen mij toe heel goed te zijn met het oog op de volksgezondheid. Want natuurlijk heeft men gewoonlijk in Inlandsche medicijnen meer vertrouwen dan in Europeesche. Daarbij hebben die dan nog het groote voordeel, dat ze overal te krijgen of te Dl. 77. 
vinden zijn, wat met de Europeesche nu juist niet het geval is of kan zijn. Werd mij dus bekend dat het een of ander middel met goeden uitslag kon gebruikt worden, dan gaf ik daar altijd zooveel mogelijk ruchtbaarheid aan.

Wanneer een man van het vak eens behoorlijke onderzoekingen kon doen in dezen, mits hij niet op het standpunt stond, dat die domme Inlanders toch niets weten, ben ik overtuigd, dat men verrassende ontdekkingen zou doen, omtrent de medicijnen die in het bosch enz. te vinden zijn.

Met wondheelerij is men minder gelukkig. Dat ligt nu ook wel voor de hand. Al zijn ook sommige bladen goed voor wondheeling, men is veel te vuil om op dit punt iets te bereiken. Van schoon en zuiver heeft men niet het minste begrip in dit verband, dus kan men ook geen wonden tot heeling brengen. Men bedekt de wonden met allerlei soort bladeren, ook wel met plaatjes bladkoper met gaatjes erin, maar tot genezing brengt men ze zelden, des te minder, waar die wonden gewoonlijk gevoed worden door de onzuiverheid van het bloed.

Toch hebben de menschen wel goed geneesvleesch, zooals men dat noemt, mits ze maar goed, of eenigermate goed, behandeld worden. Wondbehandeling is dan ook voor de zending een heel dankbaar werk, want alleen met reinheid, bereikt men al prachtige resultaten, waar de menschen versteld van staan.

Ook weet men geen raad met malaria, of andere koortsige ziekten, veel minder nog met acute huiduitslagen, zooals pokken en mazelen.

Dikwijls bereidt men de patienten een snellen dood, door ze in koortshitte te doen baden of op koude bladen te leggen, (het eerste natuurlijk niet te vergelijken met hydrotherapie).

Ik heb me den Tobelorees wel wat veel gedacht, als Christen. Laat me mededeelen, hoe het gewoonlijk gaat met een patient bij de Heidensche Tobelo's.

Wordt iemand ziek, dan is de eerste vraag: waardoor komt dit, en de tweede: wie kan hem genezen?

Om dit te weten moet men maihi, waarzeggen (zie het hoofdstuk over waarzeggen). Daardoor komt men allereerst te weten, wat de geestelijke oorzaak is van het ziektegeval, d. w. z: waarom of waardoor de geestenwereld, dit geval veroorzaakt heeft. Natuurlijk niet, wanneer men getroffen wordt door een lichte ongesteldheid, b.v.b. een verkoudheid. Die gaat vanzelf weer over. 
Neen, ernstige ziekte moet er zijn. Dan moet dus een waarzegger komen. Als die eenmaal heeft uitgemaakt wat de oorzaak is onderzoekt hij ook meteen waar de medicijn is.

Aangezien de waarzegger voor die diensten niet betaald wordt, als zijn waarzeggerij niet uitkomt, doet hij wel zijn best om het goede te vinden. Zoo zag ik meermalen, mij heel onbekende menschen, komen om medicijnen te vragen. Mijn verwondering daarover hield echter op, toen ik eenmaal wist, dat die lieden eenvoudig kwamen na de openbaring van de een of andere gomatere, dat $i k$ de medicijn wist. Was het een koortsgeval, dan was dit nogal gemakkelijk uit te maken, omdat daartegen toch niet een inlandsch medicijn hielp, en men bij mij chinine kreeg. Maar ook wel in andere gevallen, wist een behendig waarzegger zich te verzekeren van zijn betaling, door de menschen eenvoudig naar mij toe te sturen. Waren ze dan genezen, dan werd niet $i k$ bedankt, maar de waarzegger kreeg zijn belooning, bakau, want die had het dan toch maar geweten!

Echter eerst wordt onderzocht, wat de geestelijke oorzaak is van de ziekte. Wordt die niet weggenomen, dan baat alle medicijn niet.

$\mathrm{Nu}$ kan die oorzaak allerlei zijn. Is het o tokata, booze geest, dan moet de gomatere komen. Maar dikwijls is het ook iets anders, b. v. b. men heeft een tuin gemaakt op een plaats, waar o ibelihi, plaagduiveltjes, wonen, en die zijn daarover verstourd en nemen nu wraak.

Of wel, men heeft een bobugo, een eigendomsteeken gepasseerd, m. a. w., men heeft iets genomen wat van een ander was, en nu is de geest uit de bobugo daar boos om, en veroorzaakt de ziekte.

Of wel, men heeft door boosaardig zweren den toorn opgewekt van den wongemi, den stamgeest, en die is daar nu boos om.

Of wel, men heeft de bohono, de verbodsbepaling van gebruikte medicijnen overtreden, en nu veroorzaakt de beleedigde $\mathrm{Dj}$ ini de ziekte, kortom, de oorzaken kunnen heel vele zijn, nog niet mede gerekend, dat de dooden tengehono of tupua, wreken of indachtig maken, dat men hen niet goed verzorgt.

Of wel, men heeft de adat overtreden b. v. door stilletjes met een anders vrouw overspel te plegen, zonder de daarvoor door de adat geeischte boete te betalen. 
Ook is het mogelijk dat het iemands manarama, werk is, betoovering zouden wij zeggen, waardoor de ziekte komt, of ook nog - wel, iemand heeft de zieke in stilte gevloekt, of wel, hij heeft vruchten gegeten van een boom, die booselijk door een ander gevloekt was.

Men moet dus eerst deze geestelijke oorzaak uit den weg ruimen.

Heeft men een woning van ibelihi verstoord, dan moeten deze daarvoor schadeloos gesteld worden. Men zit dan 's avonds stil in het tuinhuis en brengt nu als offer voor den geest of de geesten, een schotel in het bosch, die men daar gewoon neerzet. Licht of vuur mag er niet zijn, want daar houden de geesten niet van. Ook moet het doodstil zijn.

Op de eerste schotel volgt een tweede, en zoo gaat het voort, tot men zoowat alles wat waarde heeft in het bosch bij elkaar gezet heeft. En nu wacht men af in groote spanning, of men ook eenig gerinkel hoort in de opgestapelde borden en kommen, want dit is het bewijs, dat de ibelihi komen en het offer aannemen. Hoort men iets, of meent men iets te hooren, dan is men gerustgesteld, want de patient zal genezen.

Den volgenden morgen kan men het geofferde weer binnenhalen.

Bij zekere gelegenheid was men ook met dit offeren bezig, maar onder de gasten die verzameld waren voor de plechtigheid, was ook een Christen-ouderling, die beslist niet in deze dingen geloofde. Toen nu na eenigen tijd werkelijk eenig gerinkel gehoord werd in de schotels en elk kippenvel kreeg om de nabijheid van de gevaarlijke geesten, snelde de Ouderling de woning uit, ontstak licht, en ging naar de schotels, waar hij een groote krab vond, bezig zich tegen de schotels op te werken. Men was toen natuurlijk wel erg beschaamd over het feit, dat dat nu de levenmakende geest was, maar ik weet niet of het geloof in de hocus-pocus er door verstoord werd.

Is de oorzaak een bobugo, eigendomsteeken, dat niet geeerbiedigd is, dan moet de geest daaruit verzoend worden, door het een of ander klein offer.

Heeft men valschelijk gezworen of beleedigende woorden gebruikt, dan moet een gomatere dat in orde brengen, den patient het een of ander water laten drinken en hem beprevelen, en ook een klein offer moet neergezet worden.

Heeft men overspel gepleegd, dat niet betaald is, zoodat er een onverzoende adat is, dan is daardoor de stamgeest beleedigd, 
de wongemi, naar het schijnt, wel het meest door de eeden die men bij zoo'n geval zweert, en nu moet een heele plechtigheid plaats hebben, o maihi ma doaka.

Dit woord, of deze uitdrukking, doet hier vreemd aan, want maihi beteekt waarzeggen, en op het oog heeft de zaak met waarzeggen niet heel veel uit te staan. Bedoeld zal echter wel zijn, de uitspraak, waarzegging van de wongemi, die men verbreken wil.

Men stelt zich n.l. voor, dat de stamgeest als handhaver van den eed recht overeind zit, en de eeden in de hand houdt. Worden deze hem echter te zwaar, dan buigt hij het hoofd voorover, en laat de eed vallen, hetgeen dan den dood van den betrokken eedzweerder ten gevolge heeft. Het is dus wel hieraan, aan dit besluiten of waarzeggen, dat gedacht moet worden, want heeft hij het eenmaal laten vallen, dan is het reddeloos verloren. Het besluit hiertoe, zoodra de wongemi maar naar die uitgestoken hand kijkt, verwekt dus reeds ziekte, hieraan merkbaar dat de wo ngemi de hand niet meer rechtuit gestrekt, maar zijwaarts gebogen houdt, en men moet nu haastig ingrijpen, om het besluit tot het laten vallen nog gauw gewijzigd te krijgen.

$\mathrm{Nu}$ zou men denken, dat de patient hier wel iets op tegen moet hebben aangezien dit alles hem toch beschuldigt van verboden handelingen.

Helaas is dit slechts zelden het geval, hetgeen nu juist niet voor de zeden pleit. Echter, ook als de patient weerspreekt, is de gomater niet verlegen, want het feit kan ook gepleegd zijn door een familielid, dat reeds overleden is. In dat geval, hebben de levenden het eveneens te verzoenen, want het wordt op hen gewroken. $\mathrm{Nu}$, dat kan men zich natuurlijk wel laten welgevallen, en zelfs ook nog kan het feit gepleegd zijn door een ander lid der familie, ja, zelfs door een lid van den stam.

Men moet nu aan den wongemi een offer brengen bestaande uit: een stukje van de long, van de lever, van de klier onder den voorpoot, en van de liesklier van een mannelijk buideldier (o kuho ma nauru). Dit wordt gerookt tot het gaar en droog is, en is nu het o maihi ma doa ma inomo, het eten voor het verbreken van het besluit.

Men maakt nu een tafeltje op het erf met vier pooten, die een weinig schuin in den grond gestoken worden. Is het offer 
ten behoeve van de schuld van een levende, dan staat het tafeltje een weinig schuin naar het Oosten, is het voor die van een doode dan is het naar het Westen gericht.

Boven het tafeltje wordt een primitief dakje gemaakt. Men ombindt en versiert het met jonge palmbladeren, o bilere, legt nu het eten op het tafeltje met een schild er naast, hangt ook bamboekokertjes met palmwijn aan het tafeltje en zegt nu op meer of minder luiden toon: o maihi wi doa $\mathrm{ka}$ to unangoli ai totaleo - die het besluit verbreekt, slechts zijn vogel (is dit) a i waloko iata ai derihi iata-zijn vier bamboezen drinkbekers zijn vier palmbladeren drinknapjes ai langahani ratuhumoi - zijn? honderd (ik weet niet juist wat met dit woord bedoeld wordt, maar waarschijnlijk beteekent het ook: drinkbeker) ai derihi ratuhumoi - zijn drinknapjes honderd - $\mathrm{ka}$ nenanga ma batingi - tot hier is maar de grens - uha ni mi hidutu-dutumu - hinder ons niet meer - uha ni mi kokelele - kijk niet naarons kadina ni ja oko nengoka ni higihene - gijlieden die van den landkant naar zee gaat, luister hiernaar - ngokadai ni ja iha, nengoka ni higihene - gijlieden die van den zeekant landwaarts gaat, luister hier naar - ngokadaku ni ja uku ni higihene nengoka - die van het Zuiden naar het Noorden komt, luistert hier naar - ngokadau ni ja ile, ni higihene nengoka - die van het Noorden naar het Zuiden komt luistert hier naar - o dihanga i kurutideholi - het uitspansel daar is te hoog - nengoka ni ja uku ni higihene - kom hier naar beneden, luistert er naar - mia rukiti i tudukino - dat ons touw het voor ons steke (bedoeld is hier het touw waarmede men de lanspunt vastbindt om schildpad te steken) - mia kaho i niikino dat onze honden het (wild) ons achtervolgen - mia modoi i likino -- dat in onze strikken het wild zich voor ons verhange - mia baatuku i tudukino - dat onze springlansen het (wild) voor ons steken - ka nenangino ma batingi hier is maar de grens - uha ni mi kokelelo - kijk niet (toornig) naar ons - uha ni midutu-dutumu - hinder ons niet - hu-e-e-e hu-e-e-e-e, o Tingidu wo hongan a - hoera, hoera, Tingidoe (de naam van den stamgeest) gaat naar het bosch!

Heeft men deze bezweringsformule uitgesproken, dan trekt de 
wongemi zijn hand terug, en de patient is gered, zijn leven tenminste.

Is het veronachtzamen van de dooden de oorzaak van de ziekte, dan moet natuurlijk voor die dooden gekookt worden, en een feest gemaakt.

Zijn het andere booze geesten, dan moeten die door den gomatere verdreven worden, waartoe die moet idu-idu, en zijn betaling daarvoor ontvangen. Soms doet hij daarbij de angstwekkende ontdekking dat men in de andere wereld al een huis voor den zieke gereed gemaakt heeft.

Hij moet nu opnieuw aan het werk, en men moet hem een mes geven waarmede hij wild heen en weer schermt, om het huis af te breken.

Het malle, om met een aardsch mes een hemelsch huis af te breken schijnt men niet te gevoelen, maar deze bewerking kost heel veel geld, want het is moeilijk werk natuurlijk.

Heeft iemand voor den patient $\mathrm{m}$ a $\mathrm{n}$ a ra gemaakt, dan is het moeilijk, want die zit hier of daar in het lichaam, en moet er nu uit te voorschijn gebracht worden, en dat gaat niet gemakkelijk, kan lang niet door iedereen gedaan worden (niet elk is een behendig goochelaar), en kost ook veel geld. Lukt het niet die te voorschijn te brengen, dan is het geval natuurlijk hopeloos.

En zoo zijn er nog heel veel gevallen op te noemen, die alle geestelijke oorzaken van lichamelijke kwalen kunnen zijn of worden, en het is niet te verwonderen, dat de Tobelorees in gestadigen angst leeft voor dit alles, dat hem ziek maken of dooden kan, en gaarne groote sommen betaalt voor amuletten, die hem tegen al deze booze invloeden moeten beschermen.

En nu is het natuurlijk, dat als het eene niet helpt, het andere moet helpen. Heeft men de eene oorzaak afgewend, en de patient blijft ziek, dan moet er een andere of nog een andere zijn, en men begint dan maar weer wat anders. Wanneer men bij een patient komt, die een beetje langdurig ziek is, is die letterlijk omringd door allerlei. Daar een bordje met eten voor de een of andere geest, daar weer een kopje met een cent of wat voor een ander, daar een bekken met wierook erop om weer een ander af te weren, daar een paar mooie sarongs als offer aan weer wat anders; en natuurlijk, de noodige amuletten.

En zoo sterft de patient dikwijls, omringd door dit alles.

Ook dikwijls brengt men hem naar een andere plaats, een 
ander huis, opdat de Booze geesten hem niet meer vinden zullen.

Is het heel erg, dan wordt hij zelfs wel naar het huis van den gomatere gebracht, en men begint een $\mathrm{Dj}$ in i-partij om de geesten te verjagen.

Men stelle zich voor, welk een marteling dit moet zijn voor een zwaar zieke om daar neergelegd te worden bij het woedende gedreun van eenige trommen en bekkens!

Het gebeurt ook meermalen, dat de patient tijdens het spektakel den geest geeft. Nu, dat is jammer, maar den gom atere treft geen blaam, hij heeft zijn best gedaan, maar de Booze geesten waren te sterk voor hem.

Wat nu de medicijnen betreft, wij zagen het reeds, dat men goede kent, maar de toepassing laat helaas veel te wenschen over.

Heeft de gomatere de zaak in handen, dan maakt hij de medicijn nadat hij geslapen heeft. Hoe dit zijn zal, dat hangt er maar van af, of de gomatere kruidkundige is of niet. Wanneer hij niets van geneeskunde afweet, dan maakt hij er maar wat van, maar is hij min of meer bekwaam, dan bestaat altijd de kans, dat er goede medicijn gegeven zal worden, en de patient geneest.

Bij dit woord geneest, moet men natuurlijk altijd bedenken. dat velen hun goeden naam danken aan het feit, dat Goddank de meeste ziekten niet doodelijk zijn, en ook met onschuldige middelen wel weer overgaan.

$\mathrm{Nu}$ heeft men echter nog geneeswijzen, die men wel beoefenen kan, zonder gomatere te zijn, hoewel ook de meeste gomateres zich er van bedienen. Dat is het beblazen: hiwuwu en bespuwen, hiobiri, of meest hiopuru geheeten.

Het eerste n.l. blazen kan natuurliik ieder, maar dat alleen is het hem niet, want men moet voor beide, $e n$ voor blazen, $e n$ voor bespuwen, ten eerste kennen de bezweringswoorden, en ten tweede de medicijn.

Ik werd eens geroepen bij een Heidensche vrouw, die zwaar ziek was, en dientengevolge bewusteloos. Ik trof daar een Heidensch dorpshoofd, zelf ook gomatere, die de patient voor die bewusteloosheid behandelde.

Het Districtshoofd was tegelijk met mij binnengekomen, en het dorpshoofd riep hem dadelijk toe: Hangadji, ik heb alreeds geblazen, maar het helpt niet, hier kunt alleen gij helpen, blaas 
dus dadelijk. Ergo, de kracht van het Districtshoofd moest kunnen, waartoe die van het dorpshoofd tekort schoot.

$\mathrm{Nu}$ zijn natuurlijk $e n$ blazen, $e n$ bespuwen, beiden animistische handelingen, kennelijk wil men levenskracht, gurumini, op den patient overbrengen. Echter, men hoopt wel evengoed de booze geest, die de pijn veroorzaakt (men wendt het gewoonlijk aan bij pijnen) te verjagen.

Maar, hoe animistisch ook, de bezweringsformulieren of spreuken, toonen door hun Bismillah, en andere Arabische woorden, een heel duidelijke Mohammedaansche herkomst. Echter, aangezien die spreuken een mengsel zijn van Arabisch en Tobeloreesch, bestaat ook de mogelijkheid, dat men oorspronkelijk landstaal gebruikte, maar na het indringen van den Islam, de vreemde woorden overnam, en bij de eigen formulieren voegde, om die krachtiger te maken.

Men spreekt ook wel spreuken uit in andere Halmahera talen, in het Ternataansch of Tidoreesch, en de meeste zijn zoo, dat ik er niets van begrijp.

Het zijn echter nooit universeelmiddelen maar elk dient maar voor een bepaalde pijn, voor hoofdpijn, tandpijn, buikpijn enz:

Het blazen geschiedt onder het prevelen der spreuk. Men blaast bepaald op de pijnlijke plaats, of, zooals bij de vrouw die flauw gevallen was, op de plaats die men veronderstelt de zetel der ziekte te zijn, de buik, de maagstreek, enz.

$\mathrm{Bij}$ het bespuwen bedient men zich, òf van het gewone sirihspeeksel òf wel, men kauwt iets anders geneeskrachtigs, vooral kurkumawortel, ook wel uien, spaansche peper, verschillende wortels, al naar het voorschrift, en bespuwt dan, al prevelende, de pijnlijke plaats, natuurlijk herhaalde malen.

$\mathrm{Na}$ het blazen of spuwen wordt dan nog de inwendige medicijn gebruikt, die er bijhoort.

Ook wordt nog dikwerf de pijnlijke plaats met olie bestreken, ho lauhu alles bij de blaas- of spuwkuur inbegrepen.

$\mathrm{Nu}$ kan het heel goed zijn, dat een patient al onder behandeling van den eenen geneeskunst-beoefenaar is, maar dat voor de een of andere optredende pijn, toch nog weer een ander geroepen wordt, die den naam heeft, die pijn, door blazen of spuwen te kunnen genezen.

Hier volgen een paar van de gebruikelijke spreuken:

Voor o mamata ma goli (knagende buikpijn): Bismillah 
berkatiguru, gou-goungu ana foi ma taleang, gougoungu woi ja turu lelese, bismilla rahim rahamani. Ik weet met den besten wil daaruit geen behoorlijke zin te vertalen. De bijbehoorende medicijn is o bitumu blad, en helpt dat niet, dan o kokomoko blad.

Een ander tegen o haeke ma hiri (hoofdpijn) luidt aldus: Bismillah rahim rahamani penjakit no ma hoi, bobaku no ma hoi, sjetang no ma hoi, ibelihi no ma hoi, bismilla berkati guru. Het Toboloreesch gedeelte, of liever nog, het landstaalgedeelte, want het is nog half Ternataansch, luidt: ziekte ga er uit, plaag ga er uit, duivel ga er uit, plaagduivel ga er uit. Nogal niet ingewikkeld dus zoo'n bezwering. De bijbehoorende medicijn is de achterkant van o leleko bladeren.

Een andere spreuk, zelfs aangeprezen tegen buikloop en cholera, luidt: Allah taala sakit, Allah taala membawa sakit, masi ria saku ri Allah taala, ja kim. Ook dit lijkt nog al veel op grove onzin. De niet Maleische woorden weet ik niet te duiden. Men moet eerst pinang eten hierbij, daarna een ui in den mond steken, daarna spuwen. Medicijnen werden niet aangegeven.

Tegen ziekte, veroorzaakt door booze bezwering, o wokuhu, heeft men b. v. b. de volgende afweermiddelen: Bismillah giha ma ratji se nga bodiga no ma hoi gudu-gudu, no ma hoi raro gudu: Dit is meest Ternataansch: Menschen hun vergif en hun bodiga (onder dit laatste woord verstaat men ziekmakende voorwerpen, die in het lichaam getooverd worden) doe ze er uit ver weg, verwijder ze ver weg.

Een ander luidt: Bismillah penjaki dai isa, no firi gudu-gudu, penjaki sulo isa la i firi toma ngolo to lahi se Djou Wonge, Djou Lahatala Djini bolo Widadari, aku bolo akuua aku barakati ngori, bismilla barakati Guru, dat is: Bismillah ziekte die van over zee landwaartsch gekomen is, vlucht ver weg, ziekte naar het land gezonden, die vluchte naar zee, ik verzoek het aan den heer Stamgeest, de Verheven Heer, de djini of de nimfen, kan het of kan het niet, indien het kan zegen mij, bismillah zegen de Goeroe.

En zoo heeft men er nog eene heele boel. Men is geneigd om dit wel als de oudste geneesmethode te beschouwen, omdat men dit doen kan, ook zonder go matere te zijn. 
Dat men nu bij een volk, dat aldus denkt, met Europeesche behandelingsmethode niet ver komt, is licht na te gaan, daar men altijd zegt: het eigenlijke, de oorzaak uit de geestenwereld, weet hij toch niet.

Het gebeurde ook heel dikwijls, dat men iemand behandeld had, tot op het nippertje van volkomen beterschap, maar dan verdween plotseling de patient. De gomatere had dan verklaard, dat de volkomen genezing niet volgen kan, zonder zijn hulp, en natuurlijk, nadat die hulp verleend was, was de patient dan ook dadelijk genezen, en de gomatere ging met de eer van de genezing strijken.

Eerst als het volk van de gomateres bevrijd is, begint het aan zijn eigen geneesmiddelen te denken, en, zooals wij reeds zeiden, met het oog op die eigen geneesmiddelenschat is nog wel wat goeds te doen.

Hoewel vergift en vergiftigen juist tegenovergesteld is aan geneesmiddelen en genezen, is het toch wel het best deze hier maar eerst te bespreken.

Men kent zeker vergiften, hoewel men er zoo geheimzinnig mee is, dat ik ze nooit gezien heb, ja, de namen zelfs niet ken, maar het schijnen, naar de beschrijving, meest plantaardige giften te zijn.

De uitwerking ervan zag ik meermalen.

Een Distictshoofd, uit het volk gekozen, had bij Mohammedaansche Tobeloreezen, pinang gebruikt, en sinds was hij ziek geworden. Hij verzocht meermalen om medicijn, maar ik begreep zijn ziekte niet, tot hij me mededeelde, wat hoogstwaarschijnlijk met hem gebeurd was. Hij had kwaad vermoeden opgevat, en daarom zoo goed als geen pinang gebruikt, maar hij twijfelde niet, of bij het doorsnijden der pinangnoten, die men hem presenteerde, had het vergift aan het mes gezeten, want dat was de methode. Natuurlijk had men hem willen dooden, maar hij had niet genoeg gebruikt. Hij beschreef mij zijn toestand, zeggende: Mijnheer, het is net of alles aan en in me hol is, ik voel tot niets kracht meer. Helaas was dat ook het geval met zijn denkvermogen dat sterk achteruit ging. Daar nu het Districtshoofd van de Kausche Tobelo's, den naam had veel tegengiften te kennen, ried ik hem aan daar heen te gaan, en zich onder behandeling te stellen, hij is daar dan ook hersteld, hoewel hij lang zoo flink niet was of werd als vroeger. Vermoedde men 
iets, dan was men altijd bij pinanggebruik hoogst voorzichtig. En natuurlijk, aangezien uit dezelfde pinangdoos tegelijkertijd verschillende personen gebruikten, maar men slechts voor een, dat gedeelte van het mes gebruikt, waaraan het vergift gesmeerd is, is de misdaad hoogst moeilijk te bewijzen.

Een andere wijze van vergiftigen heeft men bij het palmwijn drinken.

Een jonge man, die bij mij werkte, had op een feest een glas palmwijn gedronken, en had het niet lang daarna zoo hevig in de ingewanden gekregen, dat men dacht dat hij sterven zou, waarom men hem zoo gauw mogelijk per prauw bij mij bracht. Hij beweerde door dat glas palmwijn vergiftigd te zijn. Ik vond dat nog al gemakkelijk na te speuren, aangezien een aantal personen aan dat drinkgelag deelgenomen hadden, die allen palmwijn gedronken hadden uit denzelfden bamboekoker. Was dus de palmwijn vergiftigd, dan moesten allen ongesteld geworden zijn, temeer, omdat de meesten heel wat meer dan een glas gedronken hadden. Men antwoordde mij echter glimlachend, dat dit wel niet zoo gemakkelijk te zeggen was. De palmwijn wordt uit de lange bamboekoker in glazen geschonken.

De schenker houdt nu met zijn vingers de bladeren tegen, die men ter verbetering van den smaak in den koker doet. Het vergift is onder een der nagels van 's mans hand gestreken, en alleen wanneer hij den persoon inschenkt, met wien men kwade bedoelingen heeft, glijdt die vinger als onbemerkt, in den straal, en het vergift komt mede in het glas. Daar echter op die manier toch niet veel in het glas komen kan, moeten het wel zeer sterk werkende vergiften zijn, die men gebruikt.

In een kampong stierven drie menschen, die palmwijn gedronken hadden in tegenwoordigheid van een berucht sujet, dat vroeger soldaat geweest was, en dat men verdacht van giftmengen. Twee van die menschen heb ik onder behandeling gehad in mijn hulpziekenhuis. $Z$ e voelden zich onwel, en hadden lichte koorts met geen eetlust. Het zag er niet gevaarlijk uit, maar plotseling begonnen ze te klagen over pijn in de keel, die heel snel toenam, waarbij ze het gevoel hadden, alsof de keel dichtgesnoerd werd en na een paar uren trad de dood in.

Ik weet niet zeker meer, of het gelukt is dien kerel de misdaad te bewijzen. Men is er zoo bang voor om met de palmwijn vergeven te worden, dat men zelfs afweringsspreuken mompelt, 
als men met verdachte lieden, of met onbekenden palmwijn drinkt; hier volgt er een: bela-bela i hali mumui soro paling i soro wo masararowo masariki, wo magiribi bismillah barakatiguru. Eene vertaling weet ik hier niet van te geven.

Dat verscheidene gomateres als giftmenger berucht zijn, deelde ik reeds vroeger mede.

Vergift noemt men o ratjong, in zooverre het expres gegeven wordt.

Wordt men per ongeluk vergiftigd door het eten van het een of ander, dan noemt men dat padoha.

Men spreekt ook van waranga, en bedoelt daarmede geheimzinnige vergiften hoewel men onder dien naam ook een soort pijlgift aanduidt, naar men zegt, bestaande uit het aftreksel van een rooden steen, die in de rivier $\mathrm{Ku}$ a gevonden zou worden. Ik heb echter ook dit nooit gezien en evenmin de uitwerking ervan; ook heb ik nooit iemand ontmoet, die mij naar de vindplaats kon brengen, zoodat ik vermoed dat dit wel tot het rijk der fabelen behoort.

Men vertelde eens dat een beruchte gomatere, om zich op een kampong te wreken, een vergiftig stuk hout boven in de rivier waaraan de kampong lag, voor anker gelegd had, zoodat nu de heele rivier vergiftigd was, en niemand het water meer dorst drinken. Daar de man het echter zelf gezegd had, zal dat ook wel tot zijn bravour stukjes behoord hebben, alleen om de menschen bang te maken.

(Wordt vervolgd.) 
